\title{
Criminal Justice in Extremis: Administration OF JUSTICE DURING THE APRIL 1968 CHICAGO DisORDER*
}

\section{INTRODUGTION}

One result of recent incidents of urban violence is that increased attention has been focused on the goals and operation of the lower criminal courts. The purpose of this study is to examine the functioning of the Cook County, Illinois criminal justice system in response to the mass arrests made during the riot which followed the assassination of Dr. Martin Luther King, Jr. on April 4, 1968.

This inquiry was initiated by persons who observed the Cook County criminal system during the April riot. Outward indicia-including conditions in the jails, the inability of arrestees to contact friends, relatives, or lawyers, or to post bail, the authorities' refusal to conduct bond reduction hearings until days after the riot was officially proclaimed to be over, and the system's hostility toward volunteer lawyers and law students-suggested that under stress the lower criminal courts of Chicago had allowed the rights of defendants to be seriously abused.

Our study has indeed revealed serious deficiencies in the operation of the criminal process in April 1968. But many of these deficiencies are not unique to times of civil disorder; they are rooted in serious structural infirmities in the criminal process.

It is unfortunate that so much attention has focused on the lower criminal courts only in response to civil disorders. One recurring theme of this study is that in some respects the goals and operation of the

- This study was supported by grants from the American Bar Foundation and the Center for Studies in Criminal Justice of The University of Chicago Law School.

The study was prepared under the supervision of Roger $\mathrm{K}$. Warren, Projects Editor of the Review. Members of the Review who contributed to the study include Thomas D. Kitch, Aviva Futorian, Richard S. Frase, and Bernard Zimmerman. Mark N. Aaronson, Nelson A. Soltman, and E. Thomas Unterman, third-year law students, were employed during the summer of 1968 to work on the project. Their assistance, however, continued long after their official responsibilities terminated.

We would like to acknowledge the cooperation of the Chicago Riot Study Committee in helping us obtain relevant information and the Chicago Bar Association for making available transcripts of the bail hearings. There are, in addition, many persons-law professors, court and police officials, staff members of the Center for Studies in Criminal Justice, and colleagues-who volunteered to read and comment on earlier drafts of this study and whose generous assistance was invaluable. 
criminal system during a riot are no different than in ordinary times. In fact, Chicago had a virtually complete, though unarticulated, plan for dealing with mass arrest situations. That plan was an attempt to normalize the impact of riot cases on the criminal system and to normalize, to some extent, the impact of the criminal process on riot arrestees.

In other respects the goals and operation of the Cook County criminal system were altered to meet the particular exigencies of riot conditions. There is cause for concern that during the riot the criminal justice system may have seriously deviated from the standard of an independent, guilt-determining process. But there is cause for even greater concern in the possibility that ordinary arrestees are ultimately treated little differently from riot arrestees.

In this study we examine, in particular, charging policy, the bailsetting process, and the disposition of riot cases. We explore the problem of preventive detention and the tension between due process and efficient judicial administration. Wherever possible we make use of relevant information on the operation of the Cook County criminal system under normal conditions, and during past mass arrest situations.

Our analysis of the administration of justice during the April 1968 riot is based primarily on a statistical analysis of the official arrest and court records of 2,189 adults ${ }^{1}$ arrested between 7 p.m. on April 4 and 7 p.m. on April 11 and processed through the emergency branch of the Municipal Division of the Cook County Circuit Court. ${ }^{2}$

1 It is difficult to ascertain the exact number of adult riot arrestees. Chicago Police Department statistics show 2,574 adult riot arrests, but their figure apparently refers to the total number of charges, not defendants. Memorandum from William J. Martin, Assistant State's Attorney, to John J. Stamos, State's Attorney of Cook County, May 22, 1968. Our own sample includes 2,189 defendants: the 2,160 defendants for whom charge information was available were charged with a total of 2,439 offenses. It appears, therefore, that our sample includes approximately 100 fewer arrestees than the Police Department statistics. We have no reason to believe that our sample is biased in any respect.

Although this study is limited to an analysis of adult riot arrestees, approximately 1,200 juveniles - males under the age of 17 and females under the age of 18 -were also arrested during the ten days following Dr. King's assassination. More than half were processed through Central Police Headquarters, rather than through district police stations. But $61 \%$ were released after police processing. Of those required to appear in court 268 were released to the custody of a responsible adult and 186 were detainedmost at the Audie Home, Chicago's juvenile detention facility. Delinquency petitions were subsequently filed in approximately 350 cases. We have no information on the final disposition of juvenile cases. Chicago Riot Study Committee files [the Chicago Riot Study Committee is hereinafter cited as Austin Committee]; interview with Walter P. Dahl, Presiding Judge, Juvenile Division, Circuit Court of Cook County, September 17, 1968; letter to Nelson Soltman from Judge Dahl, August 28, 1968.

2 Included in the sample, in addition, are approximately $\mathbf{3 5 0}$ defendants whose court records did not expressly indicate that they were processed through the emergency branch but who appear-based on such information as the charge, location of arrest, arrest report, and magistrate at the bail hearing-to have been arrested for riot-associated offenses. 
The records were not always complete. Our findings are based on those cases where relevant information was available. Variation in the number of arrestees reported in particular tables reflects that fact.

We also rely on other sources. Some information, including data on the riot itself and police arrest policies, is derived from the Report and files of the Chicago Riot Study Committee. In addition, we analyzed a sample of 202 adult bail hearing transcripts, furnished through the courtesy of the Chicago Bar Association, in order to explore more fully the nature of the bail-setting process. We hired experienced black community interviewers to locate and interview, individually and in groups, a sample of riot arrestees selected at random from official court records. Within the limits of time and funds available for these interviews, our interviewers were able to locate and interview fewer than twenty arrestees. While the responses of those interviewed provided insights we could not otherwise have obtained, we have not, in recognition of the inadequacy of the sample, generalized about their attitudes.

Other sources of information include interviews with defense attorneys and other persons who had firsthand experience in public and private capacities with the administration of justice during the April riot, newspaper accounts, and the testimony of informed participants before the Illinois Advisory Committee to the United States Commission on Civil Rights. 


\section{The Cook County Gourt System}

In this study we will consider in some detail the processing of riot arrestees by the criminal justice system. Before doing so, however, it is necessary to outline briefly the organization of the Cook County courts and its procedure for handling of criminal defendants.

In 1964, a new judicial article of the Illinois Constitution went into effect. ${ }^{3}$ It established a single Circuit Court for Cook County to replace 161 separate trial courts which had previously served the Chicago metropolitan area. ${ }^{4}$ The Cook County Circuit Court is the largest municipal court system in the United States; it serves a population of nearly six million people, $70 \%$ of whom live in the City of Chicago. Organization of the Circuit Court is the responsibility of the chief judge, who is elected from among the circuit judges by the circuit and associate circuit judges and serves at their pleasure. The chief judge has "general administrative authority in the court, including authority to provide for divisions, general or specialized, and for appropriate times and places of holding court," subject only to the rule-making power of the Illinois Supreme Court. ${ }^{5}$ Supreme Court Rule 21(b) empowers the chief judge of each circuit to enter "general orders" in the exercise of his broad administrative authority. ${ }^{6}$

Judge John S. Boyle was elected chief judge of the Cook County Circuit Court in 1964 and reelected in 1967. As his first official act as chief judge, Judge Boyle issued General Order No. I, providing for the division of the Circuit Court into two departments, Municipal and County. ${ }^{7}$ The Municipal Department is further divided into six geographical districts; the City of Chicago constitutes the First District. The jurisdiction of the Municipal Department is limited to "criminal and quasi-criminal actions and prosecutions commenced by complaint or information"-misdemeanor and ordinance violation cases and preliminary hearings in felony cases. ${ }^{8}$

The Gounty Department has seven subject-matter divisions-Law, Chancery, Divorce, Probate, County, Criminal, and Juvenile. The Criminal Division, which hears "criminal actions and prosecutions

3 ILL. CONST. art. VI.

4 Id. $\S 8$.

5 Id.

c ILr. SUP. CT. R. 2l(b).

7 General Order of the Circuit Court of Cook County No. 1-2, §§ 2.1, 2.2 (1964, revised 1966) [hereinafter cited as General Order No. 1-2].

8 General Order No. 1-2, § 2.2(e). 
commenced by indictment,"9 has jurisdiction over all felonies from the time an information is filed, if the defendant waives indictment, or from the time the grand jury returns an indictment.

Figure 1 indicates the ordinary course of criminal prosecution in Cook County. A person charged in a police complaint and not arrested

FIGURE I

\section{CRIMINAL PROSECUTION IN COOK COUNTY}

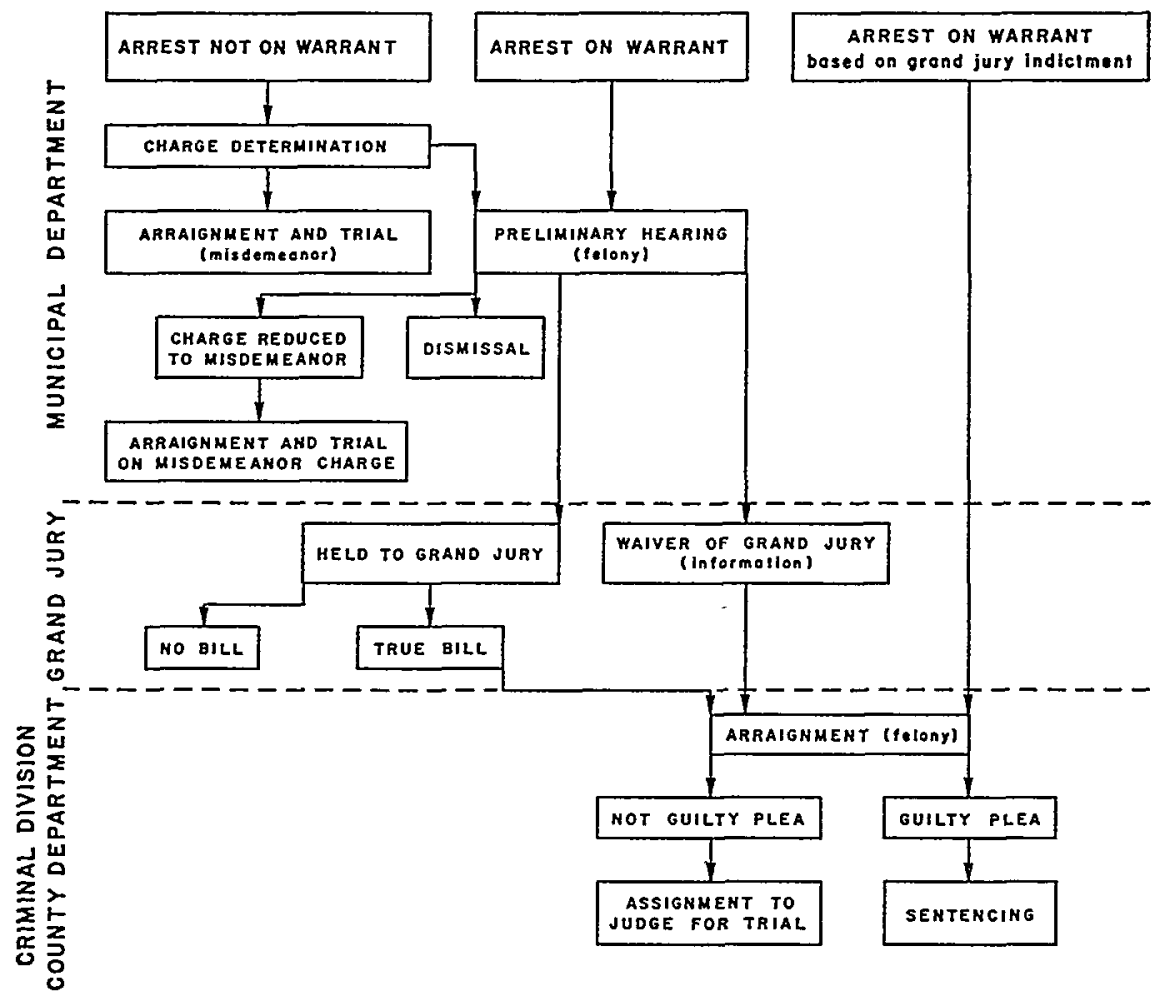

on a warrant, must be brought "without unnecessary delay" before the "nearest and most accessible" judge or magistrate. ${ }^{10}$ At the appearance the defendant is advised of the charge against him and of his right to counsel. ${ }^{11}$ In misdemeanor cases trial is often held immediately in the Municipal Department. If the defendant does not waive jury trial, or if the case is continued and the complaint is not dismissed, bail is set for the defendant. ${ }^{12}$ Where jury trial is not waived, the case is transferred to the Jury and Non-Jury Court of the Municipal Department. ${ }^{13}$

9 General Order No. 1-2, $\$ 2.1$ (VII).

10 ILL. REv. STAT. ch. 38, \& 109-I(a) (1967).

11 ILL. REv. STAT. ch. 38, \& 109-1(b)(1), (2) (1967).

12 Ill. REv. Stat. ch. 38, § 109-1(b)(4) (1967).

13 The name reflects the prevalence of bench trials even among those defendants who 
In felony cases, whether initiated by an arrest on a warrant or without a warrant, a preliminary hearing must be held to establish the existence of probable cause to believe a crime has been committed and that the defendant committed it. ${ }^{14}$ Although magistrates in the Municipal Department are not authorized to try felony cases, they are empowered to conduct preliminary hearings in such cases. ${ }^{15}$ Unless the case is disposed of at the preliminary hearing, bail is set on the defendant by the presiding magistrate. ${ }^{18}$

Under the rules of the Cook County Circuit Court, preliminary hearings in the First District (Chicago) are held in one of the branch courts of the District. Normally, cases are assigned to six of the 37 branches for preliminary hearing. Two Boys' Court branches handle all cases involving males between the ages of 17 and 21 and all auto theft cases (since such offenders are usually in this age bracket). The Narcotics Court hears all narcotics cases and non-narcotics cases involving defendants who have a history of narcotics arrests. Rackets Court has jurisdiction primarily over gambling and weapons offenders, and Women's Court handles all cases involving females over the age of 18. Felony Court handles all other preliminary hearings, including those involving murder, burglary, and robbery.

In felony cases defendants are bound over to the grand jury if the presiding judge or magistrate finds probable cause at the preliminary hearing. If the grand jury indicts a defendant bound over to it (and only in a small percentage of cases does it fail to do so) by returning a "true bill," the defendant is formally arraigned in the Criminal Division. At the time of arraignment, the defendant enters his plea before the presiding judge of the Criminal Division. ${ }^{17}$ If he pleads guilty, he is usually sentenced immediately by the presiding judge; if he pleads

initially request a jury trial. Many defendants make the request only in order to gain time to pay their lawyer, avoid a particular judge, obtain the benefit of more experienced judges and prosecutors in the Jury and Non-Jury Court (making plea bargaining more likely), or gain access to full-time criminal lawyers. Once defendants get into that court, the jury request is usually waived. See D. OAKs \& W. Lehman, A Criminal Justice SysTEM AND THE INDIGENT 15-16 (1968) [hereinafter cited as OAKS \& LEHMAN].

14 Inc. REv. STAT. ch. 38, \& 109-1(b)(3) (1967) requires the judge or magistrate to "hold a preliminary hearing in those cases where the judge (or magistrate) is without jurisdiction to try the offense"- when the charge against the defendant is a felony. $\$ 109-3$ (a) directs the judge (or magistrate) to "hold the defendant to answer to the court having jurisdiction of the offense if from the evidence it appears there is probable cause to believe an offense has been committed by the defendant."

16 ILl. Rev. Stat. ch. 37, \& 624(d) (1967).

16 ILL. Rev. Stat. ch. 38, § 109-1(b)(4) (1967).

17 ILx. REv. STAT. ch. 38, § 113-1 (1967). 
not guilty, his case is assigned to one of the judges of the Criminal Division for trial. ${ }^{18}$

In many instances felony defendants are neither dismissed nor held over to the grand jury at the preliminary hearing, since they agree to plead guilty to a misdemeanor charge or to waive their right to grand jury indictment and to be tried by information in the Criminal Division. In all felony cases the prosecution is also authorized to seek arrest warrants based on a direct grand jury indictment against a defendant, in which case the defendant's first appearance is in the Criminal Division. ${ }^{19}$

The chief judge's administrative authority under the 1964 Judicial Article is far-ranging. Judge Boyle described his responsibilities in testimony before a subcommittee of the Senate Judiciary Committee:

As chief judge ...., it is my responsibility to direct the activities of the various departments, divisions, and districts of our court utilizing the increased judicial manpower provided by the new judicial article .... In addition, I am required to hire all officers and employees of the court; prepare and administer the budget of the court; maintain all accounting and property control records; purchase law library supplies and equipment for the judges and supporting personnel; and represent the court in its negotiations relative to the establishment and maintenance of courtrooms, chambers, and office facilities. ${ }^{20}$

In addition, under Section 8 of the Judicial Article, the chief judge assigns judges and associate judges to the divisions he creates. Judge Boyle told the Senate Subcommittee:

You see, this Judicial Article becomes very flexible. We can move judges around and we assign one judge to divorce for 2 weeks and I can sign an order transferring him to the criminal court of Cook County. ...

In this one division we have the criminal court with 11 judges and we only use full circuit judges in the criminal court. ${ }^{21}$

Under the Judicial Article, the Cook County Circuit Court is

18 The defendant may still change his plea to guilty before the trial judge; in fact, plea bargaining occurs frequently at the trial stage.

10 OARS \& LeHMAN 16.

20 Hearings on S. 1033 Before the Subcomm. on Improvements in Judicial Machinery of the Comm. on the Judiciary, 90th Cong., Ist Sess. at 5 (1967).

21 Id. at 11 . 
allocated 62 associate judges and 76 circuit judges. ${ }^{22}$ Although both circuit and associate circuit judges have jurisdiction over all justiciable matters, in practice the chief judge and the presiding judges of the various courts usually assign the more important matters, such as criminal trials and civil litigation involving large amounts of money, to full circuit judges. ${ }^{23}$

The 1964 Judicial Article abolished justice of the peace and police magistrates, and provided for appointed magistrates. ${ }^{24}$ Under a statutory allocation formula, the Cook County Circuit Court is entitled to 114 magistrates. ${ }^{25}$ Magistrates have jurisdiction in civil cases involving not more than $\$ 10,000 .{ }^{26}$ Their criminal jurisdiction is limited to misdemeanors and ordinance violations with a maximum punishment not exceeding a fine of $\$ 1,000$, imprisonment in the county jail for one year, or both. ${ }^{27}$ Magistrates are authorized to preside at preliminary hearings to determine probable cause, to commit defendants prior to trial, and to set bail.28

The Cook County Circuit Court has established the procedure for the selection of magistrates in Rule $0.8 .{ }^{29}$ Under the provisions of that order, a lawyer ${ }^{30}$ seeking the position must apply to the chief judge; a committee of five circuit judges (presently, three Democrats and two Republicans) may recommend the application for appointment only after the Chicago Bar Association has approved his selection; and, finally, the full body of circuit judges must approve the appointment. Each magistrate serves for a term of one year, and is eligible for reappointment. Four magistrates were not reappointed at the end of the first year of operation of the Circuit Court in 1965; all magistrates have been reappointed each year since that time. The office of the chief judge reports that over 400 applications for magistrate positions are presently on file.

22 ILL. Const. art. VI, § 8.

23 Cook County Circuit judges are paid $\$ 32,500$ per year; associates judges, $\$ 29,000$. ILL. CoNsr. art. VI, \& 17 authorizes these salaries, which are established by law in Ir.. REv. STAT. ch. 53, \$§ 3, 3.9 (1967). Illinois uses a retention system for the election of judges. After a judge is initially elected, the electorate can only vote for or against his retention at the expiration of his six year term. ILL. CoNST. art. VI, § 11.

24 ILL. Consr. art. VI, § 12.

25 ILx. REv. STAT. ch. $37, \S 160.2$ (1967). Magistrates receive $\$ 15,000$ from the state and $\$ 4,500$ from Cook County. ILI. REv. STAT. ch. 53, $\$ 3.2$ (1967).

26 ILL. REv. STAT, ch. 37, § 622 (1967).

27 ILL. REv. STAT, ch. 37, \$ 624 (1967).

28 ILI. REV. STAT. ch. 37, \$ 624(d) (1967).

29 Cook County CIR. Cr. R. 0.8.

30 Under Cook County CIR. Cr. R. 0.8(a), "All appointees shall be persons of good moral character and reputation, and shall have been actively engaged in the practice of law for at least six years immediately preceding their appointment." 
Nearly $30 \%$ of Cook County magistrates held other jobs in the judicial system, primarily in the State's Attorney's or Public Defender's office, before their appointment. ${ }^{31}$ Nearly $40 \%$ held an appointed, non-judicial position before their selection as magistrates. Only five of the 114 magistrates are black. While state law requires that appointment of magistrates be non-partisan, ${ }^{32}$ it is impossible to determine whether this is in fact the practice in Cook County.

Of the 62 associate judges, $85 \%$ are Democrats. Nearly three-fifths were with the office of the State's Attorney or the Public Defender or held a non-judicial appointed position before they went on the bench. Five are black. Eighty-five per cent of the circuit judges are also Democrats. One-third were state's attorneys; $44 \%$ held non-judicial appointed positions. There are five black circuit judges.

Judicial reform has greatly increased the efficiency of the Cook County courts. Reforms initiated in 1964 have resulted in the gradual diminution of case backlogs and radical increase in court-collected revenue..$^{33}$ Nevertheless, caseloads are still prohibitive. Judges and magistrates handled an average of 6,898 cases each during 1967.34 Nearly 210,000 misdemeanor cases were begun, and over 205,000 terminated during the year. ${ }^{35}$ There were only one-fortieth as many felony cases: 5,323 were commenced and 4,508 disposed of in $1967 .^{38}$

But mass arrest cases-particularly mass arrest felony cases-are perceived as a threat to the increased efficiency of the Circuit Court. In the event of emergency, the chief judge is authorized to convene a special branch court, known as Branch 47 , to handle the heavy docket associated with mass arrests. Almost all cases arising from the April 1968 riots were heard in Branch 47. In order to coordinate preliminary hearings in mass arrest cases, a general order was issued in June 1966 by the presiding judge of the First District. ${ }^{37}$ Under this order, a mass

\footnotetext{
31 This data was supplied through the courtesy of Mr. Wesley Skogan, Ph.D. candidate, Department of Political Science, Northwestern University.

32 Cook CounTY CIR. Cr. R. 0.8(a).

33 In 1963 the suburban area of Cook County collected a total of $\$ 512,000$ in fines and costs; by 1967 this amount had increased to $\$ 4,881,000$. In Chicago the collection of fines increased from $\$ 9,230,000$ in 1964 to $\$ 12,048,000$ in 1967 . The addition of $\$ 10,000,000$ for various fees (filing fees, sheriffs fees, bail bond forfeitures, etc.) brought the total Chicago court revenue to $\$ 22,048,000$ for 1967 or over $\$ 27,000,000$ for the entire county for the same year. This remarkable increase is attributed to a centralized and computerized accounting system; the income from the Cook County courts in 1967 was $\$ 10,000,000$ more than the state's cost of the entire court system. AdMINistrative OfFice of the ILIINOIs COURTS, 1967 ANNUAL REPORT to THE SUPREME COURT OF ILIINOIS 19-20.

$34 \mathrm{Id}$. at 56.

$35 I d$. at 61 .

36 Id.

37 General Order of the Circuit Court of Cook County No. 66-12 (1966).
} 
arrest was defined as the arrest of 50 or more persons, excluding juveniles, "in any one incident." A detailed schedule for the conduct of preliminary hearings, according to the number and time of arrests, was established.

As a result of delay in the processing of arrestees brought to 1 th and State for bail hearings during the April 1968 riots, this order was redrafted. ${ }^{38}$ The detailed schedule of court locations and times has been eliminated and the presiding judge of the First District has been given the responsibility for opening as many bond courts as may be needed, as well as for designating magistrates to sit in these courts and notifying various city and county officials that a "mass arrest program" has been initiated by the court system.

Court officials frequently speak of the impact of riot cases on judicial administration in terms of the sheer volume of mass arrests. Commenting upon the administration of justice during the Detroit disorders of 1967, William Cahalan, Chief Prosecutor of Wayne County, said, for example:

The situation in Detroit, so far as the administration of justice was concerned during the riot was "normalcy" except that there was a lot more of it to cope with. The prisoners of the riot were processed in exactly the same manner as the arrestee in "normal" times. The only difference was a "lot more."

This "lot more" was what really gave us our difficulty. ${ }^{30}$

In contrast to Cahalan's suggestion that judicial administration in Detroit was hindered by a "lot more" cases, Chief Judge Boyle remarked after the April riots:

If we had to do it again tomorrow, I think we would handle it in the same fashion, because we could have handled an unlimited number of defendants. We could have taken care of two or three thousand more if necessary. ${ }^{40}$

And the Chief Judge's Administrative Assistant denied that even the mass arrest of 9,300 persons would have presented a processing problem for the courts. ${ }^{41}$

Although the optimistic projections of Chicago officials regarding the processing of the April rioters are doubtful in light of this study's findings, the difference of view between Detroit and Chicago officials is undoubtedly a result in part of the different charging policies imple-

38 General Order of the Circuit Court of Cook County No. 18 (1968).

39 Cahalan, The Detroit Riot, 3 The Prosecutor 430, 433 (1967).

40 Austin Committee files.

41 Id. 
mented during the two civil disorders. As we shall explore more fully in the next section, a much higher proportion of Detroit riot arrestees than of their Chicago counterparts were charged with felony offenses.

During the week of April 4-11, about 1,300 persons were arrested on riot-associated misdemeanors in Chicago and processed through the First District, Municipal Department. Approximately 850 persons were arrested on one or more riot-associated felony charges and initially processed through the same court. (See Table 1.) Since the First District disposed of an average of approximately 4,300 misdemeanor and ordinance violation cases cases a week during 1967, the volume of misdemeanor cases entering the criminal courts during the week of the riot was not dramatically greater than normal, even assuming, which is unlikely, that non-riot associated misdemeanor arrests continued at normal rates during the riot. If the impact is measured simply in terms of volume of misdemeanor cases the Cook County Court officials appear to be correct.

TABLE 1

Charge Category Breakdown of April 1968 Chicago Riot Arrestees

\begin{tabular}{|c|c|c|c|c|c|}
\hline Curfew & & 582 & Prostitution & 5 & \\
\hline State Disorderly Conduct & & 453 & Keeping a Disorderly House & 2 & \\
\hline Property Misdemeanors & & 139 & Property Felony & & 565 \\
\hline Petty Theft & 99 & & Burglary & 521 & \\
\hline Criminal Damage to Property & 22 & & Grand Theft & 40 & \\
\hline Control of Stolen Property & 14 & & Attempted Burglary & 4 & \\
\hline Criminal Trespass to Vehicle & 2 & & Robbery & & 15 \\
\hline Attempted Theft & 2 & & Armed Robbery & 8 & \\
\hline Resisting Arrest & & 34 & Robbery & 4 & \\
\hline Resisting Arrest & 13 & & Attempted Robbery & 3 & \\
\hline Obstructing Police Officer & 21 & & Personal Felony & & 9 \\
\hline Personal Misđemeanors & & 12 & Aggravated Battery & 4 & \\
\hline Battery & 9 & & Rape & 2 & \\
\hline Aggravated Assault & 2 & & Attempted Murder & 2 & \\
\hline Reckless Conduct & 1 & & Murder & 1 & \\
\hline Unlawful Use or Discharge of & & & Arson-Possession of Explosives & & 7 \\
\hline Weapons* & & 42 & Other* & & 23 \\
\hline Vice Crimes" & & 34 & Two Charges* & & 215 \\
\hline Possession of Drugs & 16 & & Three or more charges* & & 28 \\
\hline Gambling & 11 & & & &, 158 \\
\hline
\end{tabular}

- This charge category encompasses crimes which under particular circumstances may be either misdemeanor or felony offenses.

But the impact of 850 felony arrests initiated in one week is staggering. In 1967 the First District held 16,589 preliminary hearings and transferred 3,338 defendants to the Criminal Division under indictment, an average weekly load of 319 and 64 respectively. ${ }^{42}$ Thus, the

42 Administrative Office of the Inlinols Courts, 1967 AnNual Report to the SUPREME COURT OF ILLINOIS 71. 
input of 850 felony cases in one week, normally necessitating an equal number of preliminary hearings and, in many cases, leading to subsequent prosecution through the grand jury and Criminal Division (perhaps including jury trial), poses a distinct threat to the efficient operation of the criminal system.

The Cook County criminal courts attempted to alleviate the burden of mass arrests by granting continuances en masse in all criminal cases regularly scheduled for hearing at the Municipal Department courtrooms where riot arrestees were being processed during the week of April 4-11. Attorneys simply lined up at designated tables to receive automatic continuances, often of two months or longer. ${ }^{43}$ Except for the necessity of setting bond in non-riot cases, magistrates were thus freed to hear only riot arrest cases during the week of April 4-11.

43 Austin Committee files. 


\section{The April Riot: Arrest and Gharging Policies}

Dr. Martin Luther King, Jr., died of bullet wounds at 7 p.m., Chicago time, on Thursday, April 4, 1968. As the news of the assassination spread through the black neighborhoods of Chicago, ${ }^{44}$ residents began to file into churches or gather around television sets to watch newscasters repeat the same story and narrate hastily prepared film biographies of the slain leader. Although thoughts of violent revenge were articulated by a few militant groups, ${ }^{45}$ all areas of the ghetto were abnormally quiet throughout the evening.

By 8:30 p.m., city officials were in contact with Police Superintendent Conlisk, Cook County Court officials, and representatives of the State's Attorney's and Public Defender's offices to discuss precautions to be taken in preparation for the possibility of civil disorder.

The police department had taken immediate precautionary measures. At 7:45 on Thursday night all days off for members of the Field Services Bureau (containing 7,500 sworn members) were cancelled. Beginning with the first watch (12 midnight to 8 a.m.), extra men were assigned to the 2nd, 3rd, 10th, 11th and 21st districtsthose areas with a history of riot activity. In addition, special threeand four-man prowl cars began patrolling those parts of the ghetto where people were likely to gather on the streets. Department officials also contacted the commanding officer of the Emergency Operations

\footnotetext{
44 Much of the black ghetto in Chicago is in the form of a broad band which surrounds the Loop on three sides (the fourth is Lake Michigan). Within the Loop are located the city's major banks, businesses, and department stores, as well as the world's largest commodity exchange. Those who travel between the inner city and the western suburbs use the Eisenhower Expressway, which stretches directly west from the lake and Grant Park. It is approximately eight miles from the center of the Loop to the western edge of the city. Four to six miles from the Loop, the Eisenhower runs directly through the middle of one of the most impoverished areas on the West Side. Within six blocks to the north (along Madison Street) and eight blocks to the south (along Roosevelt Road) of the Eisenhower the worst property damage during the riot occurred. The preponderance of this damage was inflicted during the afternoon and evening of April 5.

45 As reported by the Austin Committee, "these groups were small in number, small in membership and were informal and ad hoc." REPORT OF THE CHICAgo RIOT STUDY COMmItTeE 5 (1968) [hereinafter cited as AUSTIN CoMmitree RePort]. Much of the material in this section is taken directly from Chapters II, III, and IV of the AUsTIN CoMMITTEE REPORT. We have also relied upon reports and interviews which were prepared by the committee staff but not published in the report. Although our conclusions conflict at times with those of the Austin Committee, the part of the report dealing with the disruption of the schools and the activities of the police department has proved a valuable guide to the analysis in this section.
} 
Headquarters of the Illinois Army National Guard. Since the City remained calm throughout Thursday evening and the early hours of Friday morning, however, it was decided not to call out the Guard immediately.

Actual disturbance began with the opening of the Gity's schools on Friday morning. One police officer reported that those students arriving at black high schools were met by "persons passing out handbills urging them to stay out of school."46 Many schools did manage to hold the memorial services suggested the previous evening by School Superintendent Redmond, but the atmosphere was tense and often charged with anti-white feelings. False fire alarms, various forms of vandalism, and other disruptions by students and outsiders caused the dismissal of school after school in the black communities. By 1 p.m. only four black high schools were still in session. Those released from one school would often move on to disrupt those schools still open, breaking windows and stopping cars along the way. In some cases, groups formed to march on white schools on the perimeter of the ghetto and, in one case, on the downtown area itself.

In the two-hour period from 11 a.m. to 1 p.m., four separate and serious incidents occurred: (1) about 1,000 students left Marshall High School and marched toward predominantly white Austin High School on the far West Side (about eight miles west of the Loop); (2) two to three hundred students from Hyde Park High School (eight miles south of the Loop) marched toward Mt. Carmel High School, a predominantly white private school six blocks away; (3) students from Cooley High School (two miles north of the Loop) disrupted classes and then marched to Waller High School, where more students joined them in harassing white motorists and breaking windows along Division Street; (4) several hundred students gathered at Crane High School (four miles directly west of the Loop) and marched east on Madison, directly into the downtown area and toward City Hall.

This last demonstration alarmed both the police and shoppers in the Loop area, even though few of the students ever reached City Hall, and police protection was sufficient to force dispersal of the students after a small number of arrests were made. As a result of the widespread disruption of schools and the demands for protection of the Loop area, police reinforcements were sent to the perimeter

\footnotetext{
46 All statements attributed to the police are taken from a written interview which was prepared and administered by the staff of the Austin Committee. 476 officers who had been on riot duty between April 4 and April 7 answered nearly 30 questions concerning composition of crowds, activities of the rioters, police procedures, and the prevention of future riots.
} 
of the inner city area in the early afternoon. From this central staging area, police personnel were equidistant from potential trouble spots in the ghetto.

During the course of Friday afternoon, the focus of the disturbances shifted from the schools and the student marches to the West Side, where looting and arson began. At 2:30 p.m. the district commanders of the Chicago police were instructed to order the closing of all liquor establishments and to prohibit the sale of gasoline in containers. But these measures did little to stem the disturbances, and by 3 p.m. the looting on the West Side was so widespread that police in the area were unable to take effective action against the offenders. People began to gather in the streets and to encourage each other to participate in the looting in an increasingly open fashion. The looting activity at this time, and throughout the weekend, tended to concentrate upon clothing, appliance, general merchandise, and liquor stores and pawnshops operated by whites.

As the afternoon progressed, a pattern developed. After a store was emptied of its contents, it would be set ablaze. Fire department records reveal that the first alarm in this area was sounded at 3:45 p.m., for a fire in a furniture store at 2235 West Madison. A molotov cocktail had been thrown through the front window. By 5 p.m. several more fires had been set and were burning as far as a mile apart; at 5:15 the fire commisisoner placed his department on emergency footing. Fire department officials later testified that a stronger wind would have brought the entire West Side into danger.

In the early period of rioting, several store owners attempted to bargain with the looters. One policeman reported the unsuccessful attempt of a clothing store owner on the West Side:

He told the people that they could take anything they wanted, but he asked that they not burn the store. They emptied the store and then they burned it.

Several police officers later stated that much of the inital breaking and entering was by young men between the ages of 15 and 20. One witness observed that there was a "carnival" atmosphere in the air, and the Austin Committee noted that those blacks who lost their homes in fires were not uniformly bitter: "Some apparently felt that their homes were already so substandard that little was lost."47

The degree of organization among the looters was unclear. Several policemen reported seeing adults direct juveniles into stores to loot, supposedly on the theory that any children arrested by the police

47 AUSTIN COMaMTrTEE REPORT 78. 
would be excused because of their age. Other police officers thought that juvenile gangs directed their youngest members to loot in order to avoid arrest of those members with long prior arrest records.

Between 3 p.m. and 5 p.m., many ghetto residents realized that the police department was temporarily unable to bring reinforcements into the West Side. A large cross-section of the community-often including entire families-joined in the looting. Nearly three-fifths of the policemen interviewed by the Austin Committee thought that fewer than $5 \%$ of the looters were arrested. This would indicate that over 30,000 people actually took part in the looting. The figure is probably inflated, but it does suggest the perception many policemen serving on the West Side had of the riot-a small rebellion in which ghetto residents were able to overwhelm the stores of their choice. By 6 p.m. the participation of black citizens in the riot probably reached its highest level. Police witnesses generally agreed that it "was all youth on the afternoon of April 5th but the majority were adults that night." As the older residents returned from work and the students became exhausted, the composition of the crowds changed.

The Austin Committee suggested that "significant errors in command judgment" may have been made "in stationing more police manpower in the Loop than was necessary during the day of April 5 while less was put into the West side."48 This criticism may reflect an unrealistic assessment of the dilemma facing the police department. Because of the widespread disruption of ghetto schools, as well as the unpredictable nature of the crowds which subsequently formed around the schools, department supervisors did not realize that the West Side would become the focus for serious riot activity until the middle of Friday afternoon.

In the area surrounding the Cabrini-Green housing complex on the Near North Side, looting and burning occurred on a much smaller scale than on the West Side. Once again, both the looting and the arson were directed toward white-owned and white-operated stores. On Friday afternoon, sniper fire from a building near a fire house at 1044 North Orleans (about one mile north of the Loop) prevented firemen from reaching a fire in a grocery store about three blocks from the fire house before the building was completely destroyed. The most serious sniping incident of the three-day weekend occurred about 1 a.m., Saturday morning, when firemen came under rifle fire from the roof of the Cabrini-Green housing complex. ${ }^{49}$ It took police

$48 I d$. at 43 .

49 Generally, news media reports of sniping incidents have been grossly overstated, as a recent study at Brandeis University has revealed. Lemberg Center for the Study of 
and National Guard forces several hours to rout the snipers from the buildings. On both the West Side and the Near North Side, firemen were hampered by residents who threw rocks and bottles or turned on hydrants to reduce water pressure, although department officials later testified that many residents helped them fight the fires. Only one fireman was wounded by sniper fire.

The South Side remained relatively calm at this time, although some store windows were broken during the evening along 63rd Street, mostly near the intersection with Halsted, about eight miles southwest of the Loop.

As the disturbances began to assume riot proportions, the police department adopted emergency measures in an attempt to meet the challenge. By 4 p.m. on Friday, the department had mobilized nearly 6,000 policemen-about half the entire force. Those officers on the eight-hour shift normally terminating at 4 p.m. had their duty extended four hours, as all members of the force began operating on 12-hour intervals. All off-duty days were cancelled and many non-uniformed personnel were shifted to uniformed police duty. Because this order was not given until after the beginning of the 8 a.m. to 4 p.m. shift (at which time there was no sign of trouble), there was no significant increase in police manpower until 4 p.m. And since heavy traffic both prevented police personnel from reaching their district stations on time and delayed their deployment immediately thereafter, there was no significant increase in manpower on the West Side until after 5 p.m.

By 9:20 p.m. on Thursday evening, more than 300 officers of the Task Force had been assigned to patrol in the ghetto areas. At about the same time, ten "incident control" teams were formed for the purpose of bringing special attention to situations which had the potential of becoming serious disturbances.50 These efforts proved effective on the morning of April 5 when the schools were disrupted. From 6 p.m. Thursday to noon Friday, 35 arrests were made in con-

Violence, Brandeis University, "Sniping Incidents-A New Pattern of Violence?" Riot Data Review No. 3, February 1969.

50 Each police district maintains two or three "tactical force" teams which consist of one sergeant and ten patrolmen who have received training in riot control techniques. In addition, the police department maintains a Task Force (about 500 men) which is normally used to break trends in crime-often in response to complaints that a particular area of the city is getting insufficient protection against a particular type of crime, such as burglary, rape, or prostitution. The members of the Task Force have also received training in riot control. Under the Mobilization Plan of the police department (see text at page 472 infra), a particular district will appeal to the Task Force or other districts for additional aid only after its own tactical force teams have been unable to quell a particular disturbance. 
nection with the school disturbances. But when the schools were dismissed, the focus of the disturbances was lost and the number of reported "incidents" increased sharply, as the students roamed the streets in an unpredictable manner. The incident control teams were unable to keep track of their activities.

It is impossible to determine whether any identifiable "Mobilization Plan" ever became operative. In 1960, early in the superintendency of Orlando W. Wilson, an "Immediate Emergency Plan" had been developed to deal with potential disturbances in the city. Under this plan, certain "mobile forces" were designated in each district, so that one district would exhaust its riot-oriented personnel before calling upon an adjacent district to help. After serious racial disturbances in the summer of 1965, a new "Mobilization Plan" was prepared. It was felt that the emergency personnel should be drawn from districts far beyond the district of incidence, so that adjacent districts would be fully staffed in case there was a "spillover" from the primary district. But during the April disturbances the traffic problem was so severe that many officers were simply told to report to the district station nearest their homes. And once it was determined that the West Side would be the center of the riot activity, department officials may not have known how many police officers were already in the area. Finally, coordination between various teams or groups entering the West Madison area was often non-existent. Communication by car radio was haphazard. As one officer noted:

Better communication between command and live personnel is needed-officers received assignments which had to be abandoned when arriving on the scene. An approach of securing a certain ... riot area could be an improvement over the ill effect of moving to a new location, and passing looters on the way.

At any rate, in addition to those officers transferred to the West Side under the Mobilization Plan, there were 300 Task Force members and 53 tactical teams (623 men) operating in the affected districts by 8 p.m. Friday evening.

The disturbances reached their peak late Friday evening. Although between 9 p.m. and midnight 116 arrests were made (see Table 2), and the fire department was fighting the largest number of fires for any one period during the riot, the looting activity began to diminish.

Glose to midnight on Friday evening, approximately $1,600 \mathrm{Na}$ tional Guardsmen joined the Ghicago police. These troops had been 
mobilized by Governor Shapiro at the request of Mayor Daley following an emergency meeting of the City Council at 2 p.m. on Friday afternoon. The Commander of the Emergency Operation Headquarters for the the Illinois National Guard was contacted in Bloomington at 2:45, and the mobilization began. Adverse traffic conditions prevented the Commander from reaching the Chicago Avenue Armory until 6:45 p.m. At this time, he received a mission order signed by Mayor Daley indicating those areas (in the Loop, Near North Side, and West Side) where Guard personnel were to be stationed. Other Guard personnel had difficulty reaching the armory. in their cars. Most of the organization and briefing of the men was not completed until 11 p.m.

The arrival of the National Guard on West Madison after midnight coincided with the arrival of a new shift of policemen. The number of arrests dropped significantly in the next six hours (92 between midnight and 3 a.m. and 48 between 3 a.m. and 6 a.m.), and it is clear that the arrival of the Guard deterred many of the people remaining in the streets. The use of armored personnel carriers and the sight of heavy weapons proved an effective method of restoring order to the area. Furthermore, all Guardsmen carried gas masks and each company had authority and training to use tear gas wherever it was needed. The distribution of duties between the Guard and the police caused some difficulty, however. Several officers made arrests on the basis of information provided by a Guardsman who either did not give his name or later failed to appear to testify at the trial of the defendant. As in the case of one police district, where a single officer signed all the complaints, convictions were clearly jeopardized by this type of arrest.

No further fires were set after the arrival of the National Guard on Friday night. Major fires were either set or continued to spread until 11 p.m. By that time there were more than 2,000 men and 100 pieces of equipment on the West Side alone. At 4 a.m. on Saturday morning, the fire commissioner declared the situation under control.

Saturday morning, a limited amount of looting occurred on the West Side, and a few more fires were set. National Guard and police responded to these minor incidents with a massive number of arrests. Between 6 a.m. and 12 noon on Saturday, 115 arrests were made. Over the weekend, arson activity was generally limited to the West Side, although both looting and vandalism were reported on the Near North and South Sides. The worst looting occurred in the vicinity of $63 \mathrm{rd}$ and Halsted, where isolated incidents of window breaking in the morning were followed by widespread looting in the early evening. 
On Saturday afternoon, General Dunn ordered the mobilization of 1,000 additional Guardsmen. This mobilization was accomplished in five hours-about half the time it had taken for the preparation of 6,000 men on Friday. By Saturday evening, nearly 4,000 Guardsmen were patrolling the streets of Chicago. At 11 a.m. Mayor Daley had announced the imposition of a curfew from 7 p.m. to 6 a.m. for all residents in the city under the age of 21.

In a final effort to secure the city, Mayor Daley also requested acting Governor Shapiro to seek the aid of federal troops. At 4 p.m. President Johnson signed an executive decree which federalized the Illinois National Guard and ordered Army troops to the City of Chicago. The transportation of Army troops from Fort Hood, Texas, and Fort Carson, Colorado, began immediately. A total of 4,000 Army troops had arrived in the city by Sunday morning, but many never left their bivouac areas at O'Hare Field and Glenview Naval Air Station, both several miles to the north of the downtown area.

The largest contingent of Army troops was located in Jackson Park, 12 miles to the south of the Loop on the Lake Shore and only a few blocks east of the University of Chicago campus. Jackson Park was the staging area for patrols in the South Side area. These patrols proved effective in crowd control, with squads of 20 or 30 soldiers routinely clearing sidewalks under the commuter " $L$ " tracks which straddle 63rd Street. Army personnel participated in very few arrests. At 11:15 a.m. on Sunday, the fire commissioner declared that the fire emergency was over and companies were ordered to return to their normal work schedule. As fire equipment was withdrawn from the West Side, city sanitation crews began to demolish burned-out buildings and to remove debris from the streets. At the same time, attempts were made to restore gas, water, and electricity to this part of the city.

The most serious property damage of the riot occurred before midnight on Friday. Yet, while there were 380 arrests on Friday, there were 632 on Saturday. (See Table 3.) The riot activity on Saturday was much more widespread, with the action on the South Side drawing some police from the Cabrini-Green housing complex on the North Side and the Madison Street area on the West Side, but it was also much less intense than on Friday. Thus, it is possible that many of those individuals who initiated the looting and arson on Friday were never arrested, while those who joined the riot activity on Saturday were much more likely to be arrested.

The combination of police and National Guard (as well as the Army after Sunday) permitted the city to regain authority in the streets, although nightfall on Saturday again brought this control 
into question. The 230 arrests made between 6 p.m. and 12 midnight reflect the new riot activity on the South Side. Less than one-fifth were for property felonies. By comparison there were 256 arrests for the same period Friday night, of which almost one-half were for property felonies. But while property felony arrests were declining, arrests for disorderly conduct increased. Less than one-fifth of all arrests on Friday night were for disorderly conduct, but this proportion rose to over a third on Saturday night. This trend may reflect the policy set by the State's Attorney's office (see discussion below), but it may also indicate that the police were in a position to arrest persons whom they thought were preparing or threatening to break into stores-as opposed to Friday night, when more people were arrested inside stores and were, therefore, charged with a property felony. A final distinction between the two nights lies in the 61 arrests made for violations of the newly imposed curfew on Saturday (for the five-hour period between 7 p.m. and 12 midnight).

Sunday afternoon, nearly all looting and arson in the city had ended. The number of arrests dropped to 383. Property felony arrests dropped from 246 on Saturday to 77 on Sunday. Once again the most active period was between 6 p.m. and 12 midnight, when 224 arrests were made. Over half of these arrests were for curfew violations; only $24 \%$ were for property felonie's or disorderly conduct.

Although schools were open on Monday, April 8, attendance in the ghetto areas was much lower than usual. Some schools held the memorial services which had been scheduled for the previous Friday. Many ghetto residents returned to work. While the number of arrests dropped to 243, the number of curfew arrests rose to 140 for the six-hour period from 6 p.m. to midnight, over $80 \%$ of all arrests made during that period. Tuesday was declared a day of national mourning by President Johnson, and the entire city school system suspended operations. Because of fears that Dr. King's funeral would cause new unrest, the curfew was left in effect Tuesday. Of the 182 arrests made between 6 p.m. and 12 midnight, 83\% were for curfew violations. On Wednesday Mayor Daley lifted the curfew and announced that the emergency was over. The departure of federal troops and the demobilization of the National Guard began. Police returned to normal eight-hour tours of duty. ${ }^{\text {.1 }}$

51 During the course of the riot, 90 policemen were injured, none seriously; 48 persons were wounded by gunfire- 20 by shots of undetermined origin and 26 by shots fired by persons in the riot area. One person was shot by a police officer in self-defense, and another claimed that he was wounded by shots fired by the National Guard. Eight persons were arrested for shootings. During the course of the riot the police recovered more than $\$ 80,000$ worth of merchandise, only $\$ 14,000$ of which was identified and re- 
Table 3 shows arrests by day and hour throughout the riot. The peak arrest period for each day was between 6 p.m. and 12 midnight. Our data also indicate that $28 \%$ of all riot arrests were for curfew, $26 \%$ were for property felonies, and $21 \%$ for disorderly conduct.

TABLE 3

Distribution of ARrests by Day and Hour From Friday, April 5Th, Through TUESDAY, APRIL 9TH

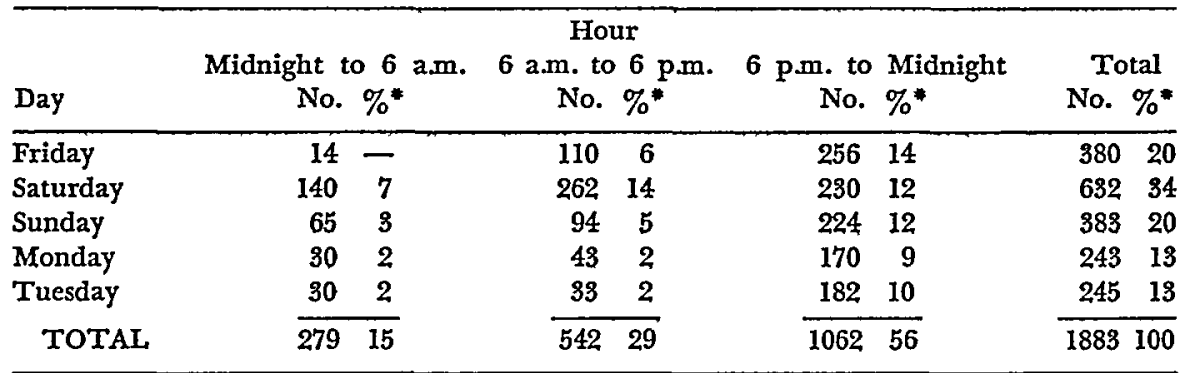

- These per cent figures are based on the total number of arrests from Friday through Tuesday. Percentage totals in this table and in tables throughout the study are subject to slight variations due to rounding of subtotals.

In summary, the pattern of arrests for the entire week was as follows: the peak arrest period for each day was between 6 p.m. and 12 midnight. (See Table 3.) Seventy-five percent of all arrestees were charged with property felonies $(26 \%)$, disorderly conduct $(21 \%)$ or curfew violations $(28 \%)$. Property felony arrests reached a peak on Friday night and diminished continuously thereafter. Disorderly conduct arrests peaked on Saturday night. By contrast curfew arrests increased continuously from Saturday through Tuesday. (See Table 2.) In short, the data reflect the reassertion by Saturday of control over the community by the combined forces of the police, Army, and National Guard. It should nevertheless be noted that the police department continued to make large numbers of arrests after Sunday$30 \%$ of all riot arrests were made after Sunday.

\section{A. Observations on Police Strategy}

During the April riot, traditional training in riot control proved ineffective. Since looting had already begun by the time the police entered West Madison in force, keeping the crowds off the streets was no longer possible. The people simply entered stores or alleys whenever the police attempted to use a "wedge" (for breaking up

turned to the owners. Austin CoMmITte REPORT 37. Throughout the riot, participants concentrated upon both looting and arson. In most cases, police were simply ignored by the rioters and there were few instances of armed conflict between ghetto residents and police. 
crowds) or a "diagonal" (for moving crowds away from buildings and into an open area) or a "skirmish line" (a holding action to block entrance to a street or other area).

Just as in the first few hours of the afternoon there had been no discernible focus to the unrest in the city as a whole, in the late afternoon and early evening the lack of a single identifiable crowd or group on the West Side to which supervising officers could direct themselves complicated the problems of the police: "People were everywhere - they were not in one place advancing in one direction."

The number of troublemakers was not small enough to permit police to make "symbolic" arrests with the expectation that cooler heads would prevail as a result. ${ }^{52}$ In addition, almost all members of the force were aware that aggressive acts on their part might intensify the riot, as in the case of the "blind pig" raid in Detroit, the traffic arrest in Newark, or the "pregnant woman" arrest in Los Angeles. Police did respond to snipers with the use of gunfire but were unable to disperse looters with the use of riot control formations, which are described in the police bulletins as a "last resort" crowd control technique.

Another problem of the police is illustrated by their difficulty in implementing the following directive issued hourly beginning Saturday morning:

Supervisors will insure that their personnel take aggressive action against all law-breakers.

Once the center of the riot was finally located, the residents of the area were either oblivious or hostile to the presence of the police. As a result, it was very difficult to detect those "law breakers" who deserved "aggressive action." No crowd would yield up an arsonist or a looter and, as one officer explained:

Naturally, as many looters as possible should be arrested, but only if you are sure they are looters. Many people were carrying items from burning homes and stores for safety

52 As a result of its study of the police department, the Austin Committee recommended the use of "symbolic arrests" in case of further disturbances in Chicago: "arrests of persons in clear violation of law who are in leadership positions and who are arrested under circumstances which may have a sobering or subduing effect on numbers of other persons in the same area." Austrn COMMITtEe Report 47. As is indicated below, the mass arrest of offenders, as well as innocent bystanders, may have been the only way to restore order in the area along West Madison. Since the police were outnumbered by the looters during the latter part of Friday afternoon, isolated arrests had little impact on the rioters. Furthermore, the influx of police unfamiliar with the people and the area made the identification of leaders (if such persons did exist) that much more difficult. 
and it was impossible to distinguish them from some of the looters.

Furthermore, many shopkeepers did not remain in the ghetto areas, so that police were deprived of the encouragement and aid which these individuals might have provided them in their attempt to protect property. Even when the merchants remained, their actions, such as the sale of merchandise at cost without receipts (thereby leading officers to think the goods were stolen), often created more confusion than their presence cured. One policeman told the following story about a clothing store owner on the West Side:

While loading several trailers with clothing, he told the crowd to let him get the trailers loaded [and they could have] what was left in the store. We stopped and arrested numerous people who were carrying clothing down Pulaski and Madison. Several minutes later the police radio informed us that these people who were coming from Pulaski and Washington were not looters, but that clothes were given to them. This was one of the most demoralizing acts to the policemen assigned to this area that $I$ have ever witnessed.

Since symbolic arrest was clearly ineffective, the individual policeman was forced to weigh the amount of time it would take to get a relatively small number of arrestees to the district station - a process often delayed by insufficient transportation, traffic jams, and the necessity of booking each individual and signing a complaint-against the value of his continued presence in the area. Many probably concluded that an arrest should not be made. One officer thought the looting was reduced significantly wherever police remained in the area:

Where policemen on foot walked through an area without making many arrests-breaking crowds and attempting. to shag looters from stores-only about 20-30 per cent of the crowd would loot. In other areas, where cars with police were passing through, it was 65 per cent or more.

When the police department finally obtained enough manpower and vehicles to begin clearing the streets with large numbers of arrests, it was getting dark and most policemen were already very tired. An indiscriminate use of the arrest power may have been caused by a combination of fear and frustration. Policemen unable to identify the "real" rioters may simply have arrested everyone in sight. The Austin Committee noted:

There may also have been a tendency on the part of the police to make arrests later on April 5 and particularly on April 6 
in a less discriminating and more sweeping way than is desirable so that a number of persons who were on the streets on legitimate business, including efforts to discipline others, including children, were incarcerated along with actual violators of the law. ${ }^{53}$

This criticism seems to be supported by the number of arrests made by the police. Between noon and 3 p.m. on Friday, only 33 arrests were made for riot-related activity. For the next three-hour period, this number increased to 64 , and from 6 p.m. to 9 p.m., 140 arrests were made for riot-related activity-the largest number of arrests made in any three-hour period during the entire riot.

Random release of prisoners was as common as random arrests. Even as late as 8 p.m. on Saturday, the transportation to district stations was still uncertain, so that police officers continued to release prisoners if no vehicles were available. The random nature of the arrests reflected neither department policy nor effective police practices. As one guideline of a police training bulletin puts it:

Mass arrests made by many police in a helter-skelter manner will serve absolutely no purpose as far as maintaining law and order is concerned.

Several policemen said that the department had no arrest policy until Saturday evening, April 6, when the National Guard was available to "secure" certain areas and the police were therefore able to pursue looters and arsonists more aggressively. One patrolman reported that he was unable to arrest looters on Friday afternoon because he had "his hands full protecting himself from objects thrown at him by the crowds that gathered." The Austin Committee asserts that upon reporting for duty on April 5, all police personnel were told to "take aggressive action against all offenders." ${ }^{4}$ But one policeman noted:

On the first day, we were told not to bother with the looters but to protect the firemen. We were not near any stores that still had merchandise. But we could see the looters carrying things about $1 / 2$ block away.

Another officer observed:

In the first days of the riot most command personnel were asking us to hold back and not to act, for fear that overt action would be detrimental to the Department. On the subsequent days (when most stores had already been burnt out) orders came down to the effect that we should become aggressive and now make more arrests-what does one do?

53 Austin CoMmitiee Report 43.

54 Id. at 38 . 
After the disturbances were over, police spoke of the ineffectiveness of traditional arrest procedures:

Arresting them doesn't seem to help because they don't care and will do the same thing when the next riot starts. . . I I personally no longer have any desire to arrest the looters. It's been my experience that they beat me out of the court back onto the street. I believe one good crack on the head does more good. If you give them a headache they go home and usually stay there.

This may sound all wrong, but you first must understand that they have no fear of being arrested or locked up. When you understand that they do not have the same fear as you and I you will finally be meeting the problem. Their values of right and wrong are quite different. Only education will help them.

Most of these people knew that police would not shoot, but if deadly force was used-the word gets around. Some of them would pass by you, and say sarcastically, "We know you can't shoot, why do you carry the gun"- "The police won't shoot, so we gonna loot."

Aside from the frustration experienced by officers forced to watch riot activity without being able to take "aggressive action," the greatest pressure on the police department was caused by the dramatic increase in the number of arrestees who were processed in certain police districts. The total number of arrests by the Chicago Police Department was $6 \%$ higher in 1968 than in 1967. The total number of arrests between March 20, 1968, and April 23, 1968 (the reporting period during which the Chicago riot occurred) increased $25 \%$ over the number of arrests effected during the comparable period in 1967. Riot arrests were made in most of the 21 Chicago police districts, but $65 \%$ were made in the five districts listed in Table 4.

TABLE 4

Number of Rrot ARrestees by Police District of ARrest

\begin{tabular}{lcccccr}
\hline & \multicolumn{6}{c}{ Police District } \\
& 3 & 7 & 10 & 11 & 18 & TOTAL \\
\hline Number of arrests & 201 & 188 & 246 & 416 & 172 & 1,349 \\
\hline
\end{tabular}

Police department arrest reports for the period from March 28, 1968 , to April 24, 1968, indicate a dramatic increase in the number 
of arrests handled by these same districts in comparison with the preceding reporting period (February 29 to March 27). (See Table 5.)

TABLE 5

\begin{tabular}{lcccccc}
\hline & 3 & 7 & $\begin{array}{c}\text { Police District } \\
10\end{array}$ & 11 & 18 & City-Wide \\
\hline $\begin{array}{l}\text { Per cent increase in } \\
\text { Index Crimes over } \\
\text { previous reporting } \\
\text { period* }\end{array}$ & $22 \%$ & $41 \%$ & $22 \%$ & $78 \%$ & $28 \%$ & $17 \%$ \\
$\begin{array}{l}\text { Per cent increase in } \\
\text { Non-Index Crimes over } \\
\text { previous reporting }\end{array}$ & $32 \%$ & $66 \%$ & $27 \%$ & $39 \%$ & $38 \%$ & $24 \%$ \\
period & & & & & & \\
\hline
\end{tabular}

* Index crimes include homicide, forcible rape, robbery, serious assault, burglary, theft (over $\$ 50)$, and auto theft. Non-index crimes include less serious offenses.

Much of this increase was registered in the first two days of the riot. Some districts unable to handle all the arrestees sent them directly to police headquarters at 11 th and State, where magistrates were available to set bond. Our data indicate that 199 of the 1,856 arrestees for whom we have relevant information ( $11 \%$ ) were taken directly to 11 th and State. The vast majority of the 199 were arrested in the 10th and 11th police districts, which are immediately adjacent to police headquarters. ${ }^{55}$ The influx of arrestees at 11 th and State began Friday evening at 6 p.m., and continued until the middle of Saturday afternoon; the arrival of prisoners caused overcrowding in the lock-up facilities, and difficulty in locating arrest records created further delay in the period between arrest and appearance before a magistrate.

The direct transportation of arrestees to 11 th and State eliminated any chance for "screening" at the district stations to release individuals known to be responsible members of the community. Although station adjustments of juveniles continued to be made (both at district stations and at IIth and State), the influx of emergency personnel made the arrest procedure more rigid than usual. Officers from other districts were unable to check out alibis or explanations for a person's presence or behavior in a particular area. With reference to the arrestees, one officer concluded: "They lived in the area of the looting but they were strangers to us as arresting officers."

Not only were traditional police strategies ineffective, but normal

55 It is possible that many more riot arrestees were actually taken to Ilth and State for final police processing after initial processing at local district stations. Initial arrest reports were our only basis for determining where prisoners were transported after their arrest. 
indices of police efficiency were not applicable during the riot. The primary concern of arresting officers was with the restoration of order and not the "clearance" of reported crimes. Many merchants later complained that those police officers coming into the area under the Mobilization Plan were not as assiduous in their law enforcement duties as were those police normally stationed in the district. ${ }^{56}$

After the disturbances were over, many merchants probably could not or did not make specific, detailed police reports of lost merchandise. Many of the crimes committed during the riot therefore never entered police records. And if such entries were made, the number of arrests and convictions was probably sufficient to cancel out the registered complaints. As a result, no individual officer or detective had to worry about meeting his quota during the disturbances. The more extreme the riot became, the less relevant were the traditional methods of measuring police efficiency.

As will become evident in the discussion below, the curfew was a very effective riot-control device ${ }^{57}$ for both the police and the prosecutor. It provided the police with a swift and effective means of removing juveniles from the street ${ }^{58}$ and it gave the State's Attorney a misdemeanor offense which could be quickly tried and which involved a relatively light burden of proof.

\section{B. The Decision to Charge}

The initial, and perhaps the most crucial, determination in the criminal justice process is whether to file charges against an arrestee and,

56 General deterioration of district authority is demonstrated by the death of four black men on the evening of April 5. All four died within the space of three and onehalf hours and within an area of two square blocks on Madison Street. The Austin Committee reported that all four died as the result of rifle fire directed into stores and alleys:

None was resisting arrest ... Allegedly two police cars containing two to

four white policemen in each car ... were seen shooting on the level into

stores... and ... the alley in question. Austin CoMmTTEE REPORT 36-37.

Such use of deadly force is in direct contradiction of police department policy and state Iaw on the use of deadly force. The most important element of this tragedy is the statement by the commander of the Fillmore Police District, where the murders took place, that neither of the police cars in question was under his authority. In the confusion of the riot, these policemen were simply "lost" within the deployment of men under the Mobilization Plan.

57 Although the curfew proclamation was of city-wide scope, it was enforced only in the riot area. We located the place of arrest of 2,112 riot defendants on a grid constructed of 10 block squares. Sixty-five per cent of non-curfew arrests were made in one of 28 such areas. Curfew arrests made in those areas, however, account for almost $90 \%$ of the total number of curfew arrests.

58 Even though almost all juvenile arrestees were released on recognizance, they were usually kept in jail overnight in order to prevent them from being rearrested for curfew violation. 
if so, for what offense. As we have seen, the sudden influx of arrestees in certain police districts, as well as the arrival of police unfamiliar with the area and its residents, virtually eliminated any screening of arrestees at the district stations during the first 24 hours of the riot. Nevertheless, someone (usually the desk sergeant in conference with the arresting officer) had to determine the offense with which the arrestee was to be charged. This decision marked the input boundary of the criminal justice system for riot arrestees in Cook County.

In many American jurisdictions, the prosecuting attorney screens arrestees and disposes of doubtful cases. In Los Angeles, for example, the District Attorney refused to issue felony complaints against 34,000 of 77,000 felony arrestees over a two-year period.59 In Washington, D.C., the U.S. Attorney's office "no-papered" 1,300 of the 9,500 felony and misdemeanor arrests by the Metropolitan Police Department in $1965 .{ }^{60}$

Under normal conditions in Cook County, however, the police department performs the preliminary screening role performed elsewhere by the prosecutor. As Oaks and Lehman observe, "the state's attorney is in the relatively unusual position of having, as a practical matter in most criminal cases, virtually no discretion in who is to be charged or what charge is to be filed." 11 The criminal complaint is prepared by the arresting officer or his supervisors at the district station. The State's Attorney rarely refuses to proceed on a police-drafted complaint and intercedes only to achieve the reduction of a felony charge to a misdemeanor.

During the riot, the normal pattern was broken, as the State's Attorney's office played a more active role in charging defendants. His office was deeply involved in the development of contingency plans for the prosecution of riot arrestees. ${ }^{62}$ On February 19, 1968, the State's Attorney and William J. Martin, the Assistant State's Attorney who subsequently directed the prosecution of the April riot cases, attended a meeting of the National District Attorneys Association Committee in Chicago. The prosecution of Detroit, Newark, and Los Angeles riot arrestees was discussed at length. The following day, the Detroit prosecutor met with the State's Attorney's staff to discuss the prosecution of rioters in more detail. He recommended that misdemeanor, rather

59 Barrett, Criminal Justice: The Problem of Mass Production, THE CourTs, THE PuBlic, AND THE LAW Explosion 85, 108 (H. W. Jones ed. 1965).

60 H. Subin, Criminal Justice in a Metropolitan Court 6-7 (1966).

61 OAKS \& LehMaN 28-29.

62 Except where otherwise noted the following discussion of the role of the State's Attorney in the prosecution of riot cases is based on information in the Austin Committee files. 
than felony, charges be used. He reported that of the more than 7,000 persons arrested during the Detroit riot, only 4,881 were prosecuted. Of this number, 3,800 were prosecuted for felonies (primarily for looting) and 1,000 for misdemeanors (primarily for violation of the governor's curfew order). The Detroit prosecutor noted that felony charges cluttered trial dockets and imposed heavy evidentiary burdens on the prosecution (his staff had filled several warehouses with evidence relating to the felony cases).

On March 22, 1968, command personnel from the Chicago Police Department met with the Corporation Counsel for the City of Chicago and Mr. Martin to discuss arrest procedures to be used during civil disorders. On March $26 \mathrm{Mr}$. Martin addressed command personnel of the police department on the problem of substantive charges for riot arrestees. He told the police officials that assistant state's attorneys would be available during civil disorders to aid in the charge decisions. In particular, it was pointed out that "looting" under Illinois law requires several elements of proof not necessary to obtain a conviction on the charge of burglary. ${ }^{63}$ Furthermore, it was noted that the offense of "mob action"64 required proof that the arrestee was "assembled" or "acting" with at least one other person and that he had heard a peace officer command him to "withdraw" from the area. As a result, it was recommended that the charge of disorderly conduct ${ }^{65}$ be used instead.

Finally, Mr. Martin advised police personnel to avoid multiple charging, and, in particular, to avoid mixing misdemeanor and felony charges, or city and state charges. On April 3, 1968, Mr. Martin met with the Administrative Assistant to the Chief Judge of the Circuit Court of Cook County and the Corporation Counsel to suggest additional plans for the processing of arrestees during a riot. The following day-the day Dr. King was assassinated-the State's Attorney contacted the Clerk of the Circuit Court and suggested the use of special form complaints, as well as the elimination of personal appearances in court by arresting officers to file complaints in the case of on-view arrests during civil disorders.

When the Chicago riot began on the 5th, the State's Attorney's office mimeographed 60,000 complaints, which incorporated the pertinent language of several Illinois statutes, in order to save time in the processing of arrestees. Assistant state's attorneys were assigned to cen-

o3 Compare, ILL. REv. Stat. ch. 38, § 42-1 (1967), with ILL. REv. Stat. ch. 38, § 19-1 (1967).

64 ILr. REv. STAT. ch. 38, \& 25-1 (1967).

65 ILL. REv. Stat. ch. 38, § 26-I (1967). 
. tral police headquarters at 11th and State and the 3rd, 7th, 10th, 11th and 18th districts to aid in the charging and processing of arrestees. The State's Attorney's office performed this service 24 hours a day through April 7. Virtually none of the riot arrestees was charged with violation of a city ordinance. As the result of appeals from convictions arising from disturbances in Chicago in 1967, the city disorderly conduct ordinance and part of the state "mob action" statute had been declared unconstitutional. ${ }^{66}$ Although a new city disorderly conduct ordinance had been enacted, it was not to go into effect until April 15. After the evening of April 5, it was therefore decided to charge riot arrestees with violations of the state disorderly conduct statute, unless more serious charges were required.

At 8 a.m. on Saturday April 6, a meeting was held at 11 th and State. Among those in attendance were an assistant to the mayor, representatives of the State's Attorney's office, the Corporation Counsel, National Guard officers, and police and detention facility personnel. At 11 a.m., apparently at the behest of those attending this meeting, Mayor Daley announced the imposition of the curfew. Curfew arrestees also were formally charged with state disorderly conduct. The curfew did not go into effect, however, until Saturday evening, and during the period between Saturday morning (when the assistant state's attorneys began to arrive at the district police stations) and Sunday night, the office of the State's Attorney continued to exercise considerable influence over the charging of arrestees.

One important consequence of the decision to rely on state statutes was that the burden of prosecuting riot arrestees fell exclusively on the State's Attorney's office, rather than the Corporation Counsel. The Corporation Counsel had been extensively criticized for the bail and charging policies implemented during earlier mass arrest situations in Chicago. Shortly before the February meeting of the National District Attorneys Association in Chicago, a Riot Control Unit was established in the State's Attorney's office to coordinate riot arrest preparations and procedure. Chicago Police Department personnel were assigned to this unit. The State's Attorney later remarked in an interview that the State's Attorney's office should be the coordinator of riot control operations because it is the only public office in direct contact with the variety of public and private bodies concerned with the problem.

Nevertheless, according to the Administrative Assistant to the Chief Judge of the Cook County Circuit Court, the Corporation Counsel undertook to act as a liaison between the State's Attorney's office and the police, and observed court proceedings as an attorney for the

66 Landrey v. Daley, 280 F. Supp. 938 (mob action), 968 (disorderly conduct) (1968). 
Police Department. There is some evidence that the Corporation Counsel exerted pressure for high bond amounts during the first two days of the April disorders. ${ }^{67}$

A second important result, in part, of the inability to prosecute for violation of city ordinance was a drastic cutback in multiple charging. In the summer of 1967, there were four minor racial incidents in Chicago. Taken together these incidents resulted in the arrest and detention of 166 persons. Eighty-one per cent of the 166 arrestees were booked on two or more charges. In one incident 49 of the 52 persons arrested were booked on four charges. 68 The unavailability of the city disorderly charge, as well as the questionable status of the state "mob action" statute, made multiple charging much more difficult during the April disorders in Chicago. Only $11 \%$ of the April arrestees were booked on more than one charge, and almost all of the multiple-charge defendants were booked on only two charges.

Multiple charging provides the prosecution with a great deal of leverage in its dealings with the defendant. A defendant charged with more than one offense will receive a higher bond, resulting in longer periods of predisposition custody and greater vulnerability to plea bargaining. The prosecution can obtain high conviction rates by agreeing to drop all charges but one, to which the defendant agrees to plead guilty. Harsh treatment of a few offenders, as in the 1967 disturbances, might have been intended to prevent small incidents from escalating into serious disturbances. But, as we have seen, riot activity on the West Side in April was widespread before large numbers of arrests were made, thus undermining the basis for an early preventive or deterrent effect.

Since the city disorderly conduct ordinance was unavailable, the assistant state's attorneys could not have charged defendants with multiple offenses unless more severe crimes had been alleged. But the State's Attorney was intent upon avoiding the high dismissal rates which were associated with the prosecution of riot felony defendants in other cities, a result criticized by the Kerner Commission. ${ }^{69}$ Maxi-

67 See text at note 124 infra.

68 Data concerning the 1967 mass arrest incidents are based on information gathered and supplied to our staff by Mr. Isaac D. Balbus, Assistant Professor of Political Science, Princeton University, through the cooperation of the Chicago office of the American Civil Liberties Union. For a comparative study of the response of three different local criminal court systems, including Chicago's, see Mr. Balbus' forthcoming doctoral dissertation to be filed in the University of Chicago Library. Mr. Balbus' research in Chicago was undertaken in collaboration with our own; his contribution to our project included not only the 1967 data but also consultations with our staff throughout the course of our research.

69 Report of the National Advisory Commission on Civil Disorders 184-5 (1968) [all citations are to the official edition, hereinafter cited as KERNER COMMISsION REPORT]. 
mum use of misdemeanor charges, as had been suggested by the Detroit prosecutor, was more likely to result in high rates of conviction because the evidentiary problems are less severe than in felony cases. Furthermore, by limiting the number of felony complaints the staff of the State's Attorney's office was free to concentrate on the evidentiary problems of a smaller number of felony cases. Since assistant state's attorneys were influencing the charge at the district station, arrestees on the second and third days of the riot were more frequently charged according to the evidence possessed by the arresting officer than on the basis of evidence which might be gathered later. And, as we noted in Section I, the impact of a large number of riot misdemeanor cases on already overcrowded court dockets is less severe than the threat of a large number of felony cases.

Once the curfew was put into effect, the demands of the police for the restoration of order were met since all those under 21 could be arrested if they were found outside after 7 p.m. The curfew also enabled the court system to operate efficiently without the intervention of the State's Attorney or his assistants since there is no prosecutorial discretion in a curfew violation. As the Chicago Sun-Times reported, the curfew was instituted to "quell rioting." "70 Discretion by the arresting officer was nearly eliminated, as the Corporation Counsel announced that there would be "no exceptions" to the enforcement of the curfew-ceven if the person under 21 is accompanied by a parent or has a job that requires them out after 7 p.m."' 71 In effect, the widespread use of the curfew arrest returned control of the city streets exclusively to the police department. Even though the Austin Committee concluded that by "late in the morning and during the afternoon of April 7, it became increasingly apparent that relative calm was being restored to the city,"72 police personnel made nearly 800 arrests after that time, $60 \%$ of which were for curfew violations. Although there is some doubt that the subsequent curfew arrests were necessary for the maintenance of order, court authorities apparently did not discourage mass curfew arrests, probably because curfew cases had a minor impact on the court system. Since evidence of age and of time of arrest were the only relevant factors, these cases could be easily disposed of on the merits.

The large number of curfew arrestees obviously affected the aggregate age and employment status statistics of riot arrestees in general. Identifiable characteristics of the arrest population are discussed in the next section.

70 Chicago Sun-Times, April 7, 1968, at 4 (four star edition).

71 Id. at 60.

72 AUSTIN COMMTTTEe Report 18. 


\section{Charagteristics of the Ruot Arrestees}

The Austin Committee found that "participation in the riots and disorders was limited to a small fraction of the city's total population, to a small fraction of the city's black population and to a small minority of the residents of the immediately affected areas." 73 In this section, we examine the characteristics of those adults (males 17 years or older, females 18 or older) who were arrested for riot-connected offenses. Our data are derived from court and police records of 2,189 adults processed through the Municipal Department. We have no demographic information on the approximately 900 juveniles who were arrested during the riot.

Detailed data on the characteristics of the adult arrest population are presented in Table 6 . Our data indicate that $94 \%$ of the adult riot arrestees were black, and $92 \%$ were male. The median age of arrestees was 20; $70 \%$ were 25 years old or younger; $57 \%$ were employed, $29 \%$ unemployed, and $11 \%$ in school. Two-fifths were unskilled laborers, $15 \%$ were semi-skilled; $38 \%$ were born in Cook County and another 5\% elsewhere in Illinois. Half were born in the South $-25 \%$ in Mississippi, $8 \%$ in Arkansas, $6 \%$ in Alabama, and $13 \%$ in the twelve other southern states. Only $29 \%$ had been arrested before; $17 \%$ had previous misdemeanor arrests and $20 \%$ had a felony arrest record. Seventeen per cent had previous convictions; $10 \%$ had been convicted more than once.

These data must be interpreted cautiously. Much of the information is based on police-recorded responses on arrest records. In a significant number of cases, data on employment status, occupation, and state of birth were not recorded. Occupation data represent our classification of widely differing terminology employed by police personnel. Data on prior criminal records are taken from prior arrest forms maintained by the Police Department. It is possible that the tabulation understates the number with criminal records because prior arrest records were not available for all defendants.

Comparable data about riot arrestees in Washington, D. G. in April 1968 and Detroit in August 1967 indicate that the Chicago arrestees were younger, more often unemployed, and less often had prior criminal records. Summary comparative data are presented in Table 7.

These data are useful only for the most general comparisons. It is probably true, as these figures suggest, that there were differences in

73 Austin Commitree REPORT 3. 
TABLE 6

Characteristics of Adult Arrestees

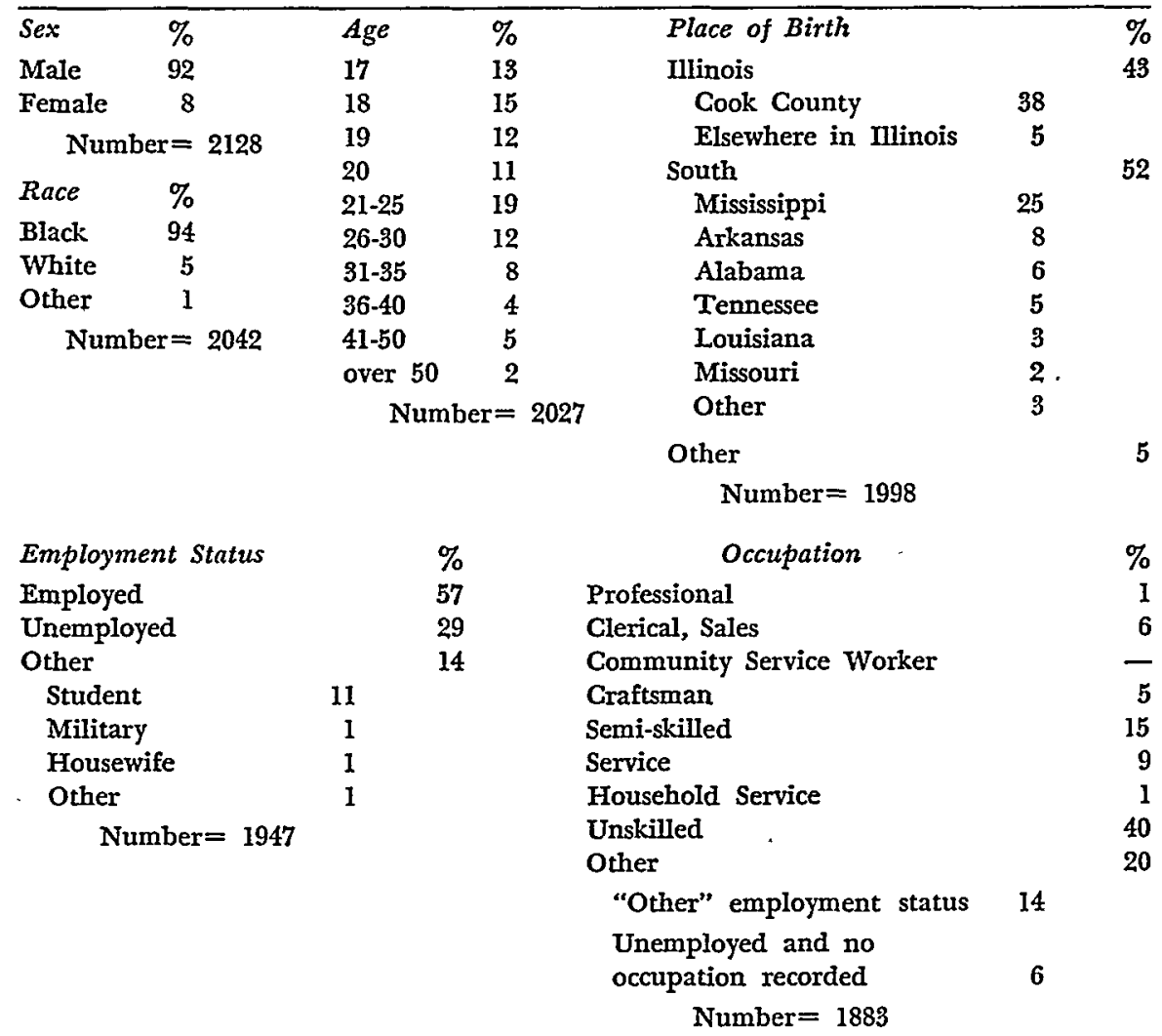

Prior Criminal Record

\begin{tabular}{|c|c|c|c|c|c|}
\hline $\begin{array}{l}\text { Number of Prior } \\
\text { Arrests/Convictions }\end{array}$ & $\begin{array}{c}\text { Total } \\
\%\end{array}$ & $\begin{array}{c}\text { Felony } \\
\%\end{array}$ & $\begin{array}{c}\text { Misdemeanor } \\
\%\end{array}$ & $\begin{array}{c}\text { City } \\
\text { Ordinance } \\
\%\end{array}$ & $\begin{array}{c}\text { Prior } \\
\text { Convictions } \\
\%\end{array}$ \\
\hline \multicolumn{6}{|l|}{ None or } \\
\hline no record & 71 & 80 & 83 & 97 & 83 \\
\hline 1 & 9 & 8 & 8 & 2 & 7 \\
\hline $2 \cdot 3$ & 9 & 7 & 6 & I & 6 \\
\hline $4-5$ & 5 & 3 & 2 & - & 2 \\
\hline $6-10$ & 4 & 1 & & 一 & 1 \\
\hline 11 or more & 2 & 1 & 1 & 一 & 1 \\
\hline Number $=$ & 2189 & 2189 & 2189 & 2189 & 2189 \\
\hline
\end{tabular}

* The first four columns refer to percentage figures for prior arrests and the fifth column refers to percentage figures for prior convictions.

the characteristics of riot participants in each city. But there are also differences among the population in the riot areas in each city which are undoubtedly reflected in the composition of the arrested group. 
TABLE 7

Characteristics of Adult Riot Arrestees: Chicago, Washington, Detroit

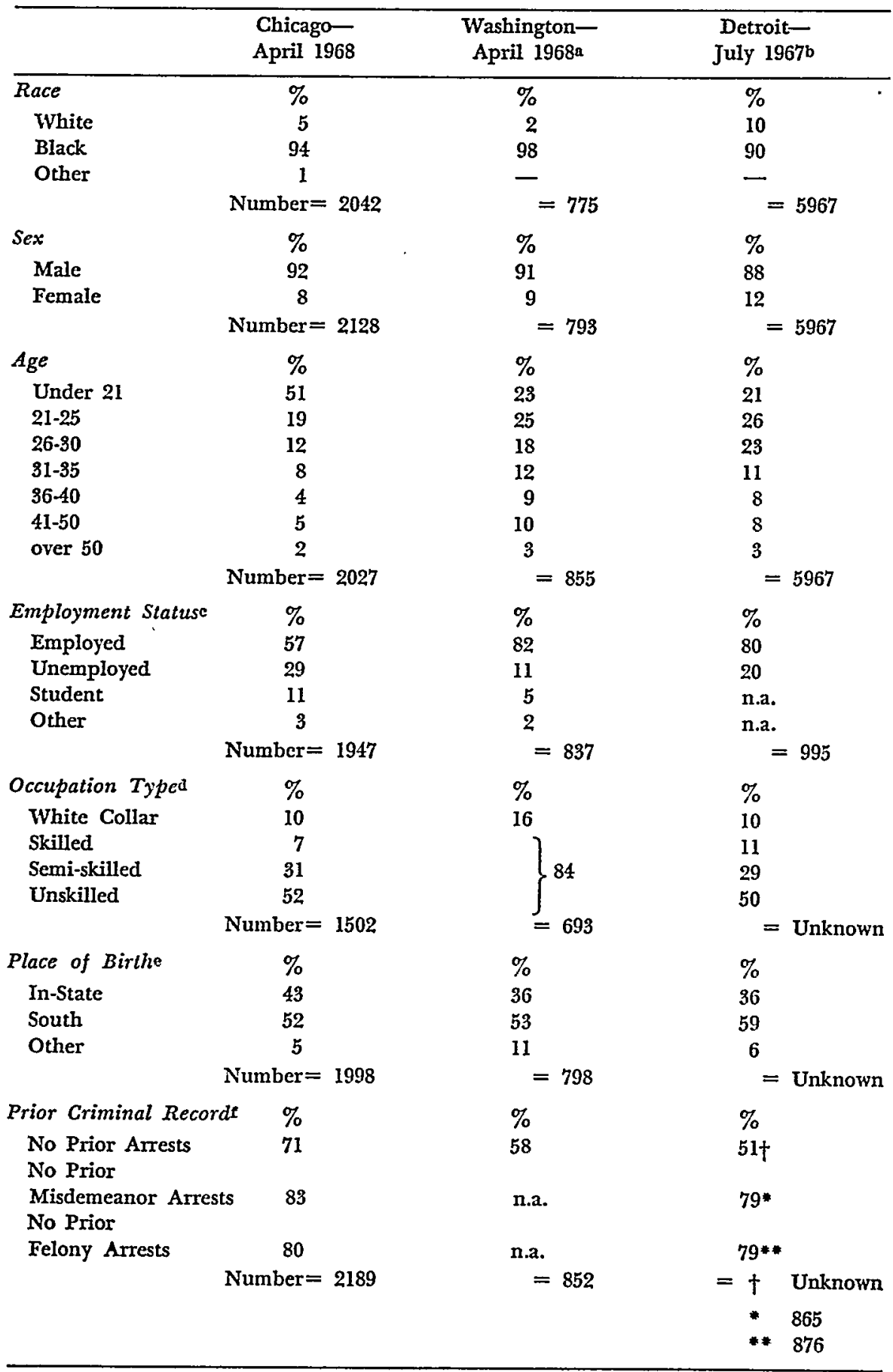


TABLE 7 (continued)

a Data in this table concerning the April 1968 Washington arrestees are taken from TEN BLOCKS FROM THE WHIrE House 226-35 (B. Gilbert ed. 1968).

b Data in this table concerning the August 1967 Detroit arrestees were drawn, except as otherwise indicated, from a report of the Detroit Police Department published in J. Lincoln, The Anatomy of a Riot 128-30 (1968).

c Some modification of the source table for the Washington 1968 arrestees was necessary to conform to the format of the Chicago study; see Gilbert, supra note a. The estimate for the 1967 Detroit riot is based on a survey of Detroit riot arrestees incarcerated in the Southern Michigan State Prison. See Colista \& Domonkos, Bail and Civil Disorder, 45 J. URBan LAw 815, 832 Table 6 (1968).

d The figures given in this category for the 1968 Washington arrestees were compiled from the same table as were those in the previous category; see note c supra. The data in this category for Detroit, 1967, were drawn from Fogelson \& Hill, Who Riots? A Study of Participation in the 1967 Riots, in SUPpLEMENTAL Studies FOR THE NATIONAL AdvisoRY Commission on Crvir Disorders 219, Table 7 at 236. The source did not include numerical totals.

e The percentages in this category for Detroit, 1967, were taken from Fogelson \& Hill, supra note d, Table 6 at 235 . No numerical figure was available.

f The prior arrest records for the 1968 Washington riot arrestees were not reported in terms comparable to the felony-misdemeanor classification employed in the Chicago study. See Gilbert, supra note a at 233. The percentages for the Detroit, 1967, arrestees were taken from KERNER CoMmission REPORT 190 n.17; Colista \&: Domonkos, supra note $c$, Tables 12,13 at 834 .

Even more significantly, there were differences in arrest and charging policies in each city. The Chicago curfew applied only to those under 21, while Detroit and Washington had curfews applicable to the entire population. Our data suggest, however, that the high proportion of young arrestees in Chicago, in comparison with Washington and Detroit, does not fully account for the relatively small number of employed persons or persons with no prior arrests among Chicago arrestees. ${ }^{74}$

Our own data on Chicago arrestees shed some light on the arrest process during the riot. The preponderance of arrests occurred on the street, or in or around stores, and relatively near the arrestee's home. More than a third were unaccompanied when arrested, and another $45 \%$ were arrested in groups of five or less. To be more specific, of 2,058 arrestees for whom police arrest records show the nature of the arrest premises, $32 \%$ were arrested at stores, $60 \%$ on the street, $5 \%$ at residences, and only $1 \%$ in automobiles. Of 1,960 arrestees for whom home address and arrest location are recorded, nearly $30 \%$ were ar-

74. Assuming that the proportion of arrestees in each age group who are employed or have no prior criminal record is the same in Washington and Detroit as in Chicago, the different age distribution of arrestees in the former two cities accounts for less than half the difference between those cities and Chicago in the incidence of prior arrests, and for less than one-third the difference in employment status statistics. 
rested within two blocks, $50 \%$ within five blocks, $65 \%$ within ten blocks, and $77 \%$ within twenty blocks of their homes. ${ }^{75}$ Of 1,832 for whom information is available, $35 \%$ were arrested alone, $20 \%$ with one other person, $12 \%$ with two others, $13 \%$ with three or four others, and $19 \%$ in groups of more than five.

In the preceding section we presented data on the time of arrest for those charged with various offenses. It is also possible to compare other characteristics of suspects arrested at different stages of the riot. Table 8 shows the percentage of those arrested during each stage of the riot who had prior arrest records. A significantly higher percentage of those arrested Friday night and Saturday had prior arrest records, in each charge category, than did those arrested early in the riot or on Sunday. Except for arrests on property misdemeanor charges (of which there were only 14 after Sunday), the percentage with prior arrest records peaked duing this early period of the riot. Table 8 also demonstrates that the proportion of arrestees with prior criminal records varies directly with the severity of the charge.

It is possible, however, that the relatively large number of persons with prior arrest records arrested on Friday night and Saturday merely reflects different demographic groups arrested during each time period. Table 9 shows, for example, that persons under 21 constituted an increasing proportion of the arrest population over the riot period, while the percentage of the arrest population comprised of persons over 21 generally declined. And Table 10 demonstrates that the proportion of arrestees who were employed peaked on Friday night and Saturday, while the proportion of student arrestees gradually increased over the

75 We also computed data on this variable for selected charge categories. The results are as follows:

\begin{tabular}{|c|c|c|c|c|c|c|}
\hline $\begin{array}{l}\text { Distance } \\
\text { from } \\
\text { Home to } \\
\text { Arrest }\end{array}$ & $\begin{array}{c}\text { All } \\
\text { Charges }\end{array}$ & Curfew & $\begin{array}{c}\text { Disor- } \\
\text { derly }\end{array}$ & $\begin{array}{c}\text { Prop- } \\
\text { erty } \\
\text { Misde- } \\
\text { meanors }\end{array}$ & $\begin{array}{c}\text { Prop- } \\
\text { erty } \\
\text { Felonies }\end{array}$ & $\begin{array}{c}\text { Multiple } \\
\text { Charges }\end{array}$ \\
\hline $0-5$ blocks & $50 \%$ & $57 \%$ & $45 \%$ & $48 \%$ & $45 \%$ & $55 \%$ \\
\hline $6-20$ blocks & 27 & 23 & 30 & 23 & 34 & 21 \\
\hline \multicolumn{7}{|l|}{ Over 20} \\
\hline blocks & 23 & 20 & 25 & 30 & 22 & 25 \\
\hline & $100 \%$ & $100 \%$ & $100 \%$ & $100 \%$ & $100 \%$ & $100 \%$ \\
\hline Number $=$ & 1960 & 546 & 414 & 128 & 499 & 189 \\
\hline
\end{tabular}

As might be expected, a greater proportion of curfew arrests occurred within $\mathbf{5}$ blocks of home than did arrests for other charges. Less expected is the relatively high percentage of property felony arrests within 20 blocks of the arrestees' homes. 
TABLE 8

Prior ARrest Records by Time of ARrest for Various Gharges

\begin{tabular}{|c|c|c|c|c|c|}
\hline \multirow[b]{2}{*}{ Charge } & \multicolumn{5}{|c|}{$\begin{array}{c}\text { Per Cent of Those Arrested Who Had Prior } \\
\text { Arrest Records }\end{array}$} \\
\hline & $\begin{array}{c}7 \mathrm{pm} \\
\text { Thursday- } \\
6 \mathrm{pm} \\
\text { Friday }\end{array}$ & $\begin{array}{c}6 \mathrm{pm} \\
\text { Friday- } \\
\text { Midnight } \\
\text { Saturday }\end{array}$ & Sunday & $\begin{array}{l}\text { After } \\
\text { Sunday }\end{array}$ & Total \\
\hline Curfew (555) & - & $25 \%$ & $3 \%$ & $17 \%$ & $15 \%$ \\
\hline $\begin{array}{l}\text { Disorderly conduct } \\
\quad(415)\end{array}$ & $7 \%$ & 48 & 16 & 23 & 33 \\
\hline $\begin{array}{l}\text { Property misdemeanors } \\
\text { (125) }\end{array}$ & 27 & 46 & - & 50 & 40 \\
\hline Property felonies (517) & 38 & 48 & 30 & 25 & 42 \\
\hline Multiple charges (193) & 47 & 51 & 25 & 24 & 38 \\
\hline $\begin{array}{l}\text { Total-all charge } \\
\text { categories (1975) }\end{array}$ & 23 & 46 & 15 & 20 & 31 \\
\hline
\end{tabular}

riot period. ${ }^{76}$ The pattern of arrests over time is undoubtedly attributable in part to the curfew proclamation which went into effect on Saturday.

But the large number of persons with prior criminal records arrested during the peak riot period cannot simply be attributed to their age

TABLE 9

AGe by TIME OF ARREST

\begin{tabular}{lcccc}
\hline Age (in years) & $\begin{array}{c}7 \text { pm Thursday- } \\
6 \text { pm Friday }\end{array}$ & $\begin{array}{c}6 \text { pm Friday- } \\
\text { Midnight Sat. }\end{array}$ & Sunday & $\begin{array}{c}\text { After } \\
\text { Sunday }\end{array}$ \\
\hline Under 21 & $30 \%$ & $37 \%$ & $56 \%$ & $71 \%$ \\
$21-25$ & 27 & 24 & 18 & 11 \\
$26-35$ & 24 & 28 & 15 & 10 \\
Over 35 & 19 & 11 & 11 & 7 \\
\cline { 2 - 5 } & $100 \%$ & $100 \%$ & 377 & $100 \%$ \\
Number $=$ & 135 & 877 & & 585 \\
\hline
\end{tabular}

and employment status. Although only $20 \%$ of the student arrestees had prior criminal records in comparison to $35 \%$ of the employed arrestees, $32 \%$ of the unemployed arrestees also had a prior arrest

76 Even when we controlled for age we found that the percentage of arrestees who were employed was generally greater during the peak riot period than during earlier and later phases. This may, in part, reflect the fact that the riot peak occurred over a weekend when employed persons were more likely not to be working. But the gradual increase in proportion of student arrests over the riot period primarily reflects the increased proportion of arrestees who were under 21 during the later stages of the riot. 
history. ${ }^{77}$ And, as Table 11 demonstrates, the percentage of arrestees with prior arrests is substantially higher during the peak riot period in each age category than during earlier or later phases of the riot.

TABLE 10

EMPLOYMENT Status BY TIME OF ARREST

\begin{tabular}{lcccc}
\hline $\begin{array}{l}\text { Employment } \\
\text { status }\end{array}$ & $\begin{array}{c}\mathbf{7} \text { pm Thursday } \\
6 \mathrm{pm} \text { Friday }\end{array}$ & $\begin{array}{c}\mathbf{6} \text { pm Friday- } \\
\text { Midnight Sat. }\end{array}$ & Sunday & $\begin{array}{c}\text { After } \\
\text { Sunday }\end{array}$ \\
\hline Employed & $51 \%$ & $65 \%$ & $51 \%$ & $\mathbf{5 2 \%}$ \\
Unemployed & 37 & 25 & $\mathbf{3 5}$ & 29 \\
Student & 7 & 7 & 11 & 18 \\
& $95 \% *$ & $\mathbf{9 7 \%}$ & $\mathbf{9 7 \%}$ & $\mathbf{9 9 \%}$ \\
Number $=$ & 123 & 842 & $\mathbf{3 5 5}$ & $\mathbf{5 7 0}$
\end{tabular}

"Totals do not equal $100 \%$ because those whose employment status was "other" are omitted.

TABLE 11

Percentage of arrestees with Pror Arrest Records by Age and Time of Arrest

\begin{tabular}{lcccc}
\hline Age (in years) & $\begin{array}{c}7 \mathrm{pm} \text { Thursday- } \\
\mathbf{6} \mathrm{pm} \text { Friday }\end{array}$ & $\begin{array}{c}6 \mathrm{pm} \text { Friday- } \\
\text { Midnight Sat. }\end{array}$ & Sunday & $\begin{array}{c}\text { After } \\
\text { Sunday }\end{array}$ \\
\hline Under 21 & $\mathbf{3 3 \%}$ & $38 \%$ & $\mathbf{9 \%}$ & $20 \%$ \\
$21-25$ & 24 & 51 & 21 & 24 \\
$26-35$ & 16 & 53 & 28 & 23 \\
Over 35 & 15 & 47 & 12 & 14 \\
\hline
\end{tabular}

These data show that the police were apprehending different groups of the population at different times during the riot. As the previous section indicated, however, there was no planned police arrest policy; to the contrary, arrests tended to be random. It can be hypothesized, therefore, that the characteristics of the participants in those activities which led to arrest-whether in a crowd on the street, in or near a store which was being or had been looted, or simply near a police officer in the riot areas-changed over time. Indeed, the Austin Committee suggested that this was the case:

Especially during the first hours of the disorders on April 5 the followers of ["a relatively small number of so-called 'natural leaders' '] were predominantly young people. Later on April 5 and on April 6 many older residents of the riot areas joined in the looting. ${ }^{78}$

Nothing in our arrest data disproves this finding.

77 Only $14 \%$ of those arrestees for whom no employment status information was available had prior criminal records, which suggests that many of those persons may have been students. If this inference is correct our data on employment status may understate the proportion of student arrestees.

78 AUSTIN COMIMTTEE REPORT 3. 
Our primary concern, however, is not with hypotheses about the characteristics of riot participants based on arrest data. Rather, it is with what happened to those who became involved in the criminal justice process. It is unclear how many of those arrested actually participated in the riot, and whether those arrested were typical of the riot participants. But the characteristics of the riot arrest population are obviously important in assessing the character of the criminal process. We will consequently be dealing in later sections with many of these characteristics, as they affected bail, time spent in pretrial detention, formal disposition, and sentencing.

The fact of arrest during the riot resulted in hardship to arresteesoften including incarceration for prolonged periods before trial in inadequate detention facilities. Some of those thus punished were obviously guilty of criminal acts; but others were not. The bail policies implemented during the April disorders constituted the primary sanction of the criminal process for many arrestees. In the next section we shall explore those policies and their consequences in some detail. 


\section{Post-Arrest Detention and Bail}

Most adults arrested during the April disorders were booked by police officers at district stations, and then transported to the temporary detention facilities at 11 th and State Streets, central headquarters of the Chicago Police Department and location of the courtrooms of the Cook County Circuit Court, First District, Municipal Division. Over 200 adult arrestees, however, were transported directly from the site of arrest to 11th and State to be booked by police.

The temporary detention facilities at 11 th and State rapidly became overcrowded as prisoners were brought in from police district stations and awaited preliminary examinations and bailsetting. Consequently, as the First Assistant Public Defender of Cook County acknowledged, in many instances it was necessary "to speed up [the preliminary examination] so that they could then be moved from 11th and State out of that building to make room for the next prisoners."79

The overcrowding at 11 th and State, and hurried bond hearings, could have been avoided. The Circuit Court of Cook County made inadequate use of existing judicial personnel and courtroom space. Although, effective April 5, Chief Judge Boyle designated 14 courtrooms at 26 th and California for emergency bond hearings, few were ever used. ${ }^{80}$ On the evening of April 5, only four courtrooms were open for bond hearings at 11th and State, one of them for juveniles. ${ }^{81}$ After the Mayor's Emergency Proclamation instituting the riot curfew was announced at 11 a.m., April 6, two additional bond courts were opened at 26th and California in the Criminal Court Building. ${ }^{82}$ But less than 50 defendants were transported from 11th and State to 26 th and California for bond hearings on Saturday evening and Sunday morning. ${ }^{83}$ Thus, throughout the disturbances adult bond hearings were confined overwhelmingly to three courts sitting in approximately eight hour shifts at 11 th and State.

On April 5, Chief Judge Boyle assigned all judges, associate judges,

\footnotetext{
79 Open Meeting Before the Illinois State Advisory Committee to the United States Commission on Civil Rights 218, 223 (June 12, 1968) (Testimony of Thomas Cawley) [hereinafter cited as Cawley Testimony].

80 Special Order of the Circuit Court of Cook County No. 68-37 (1968); see also AustrN COMMITTEE REPORT 87.

81 Austin Commitee Report 85.

82 Id. at 87 .

83 The Administrative Assistant to Judge Boyle noted that few cases were heard at 26th and California on April 6. Austin Committec files.
} 
and magistrates of the Circuit Court to the Juvenile Division as a precautionary measure. ${ }^{84}$ But only magistrates were in fact assigned to bond courts. According to Boyle's Administrative Assistant, magistrates rather than judges were assigned because they had experience in setting bond and conducting preliminary examinations, were generally younger, and had the physical stamina to handle mass arrest cases. ${ }^{85}$ Twenty magistrates of the Cook County Circuit Court conducted over $90 \%$ of the initial bond hearings for approximately 2,200 adult defendants.

The Illinois Code of Criminal Procedure requires that a person arrested without a warrant be taken "without unnecessary delay" before the "nearest and most accessible" judge where he shall be informed of the charge against him and admitted to bail in accordance with law. ${ }^{86}$ Persons charged with non-capital offenses must be admitted to reasonable bail. 87 The Code of Criminal Procedure provides that the amount of bail shall be:

(1) Sufficient to assure compliance with the conditions set forth in the bail bond;

(2) Not oppressive;

(3) Commensurate with the nature of the offense charged;

(4) Considerate of the past criminal acts and conduct of the defendant;

(5) Considerate of the financial ability of the accused..$^{88}$

Bail for a misdemeanor punishable by fine only cannot exceed twice the amount of the maximum penalty. ${ }^{89}$ Thus, for state disorderly conduct-with which curfew violators, as well as those arrested for disorderly conduct, were charged-maximum bail under this provision is $\$ 1,000.90$

Illinois has a $10 \%$ cash deposit provision. A defendant may obtain his release by executing a bail bond and depositing $10 \%$ of the amount

\footnotetext{
84 Special Order of the Circuit Court of Cook County No. 68-32 (1968).

85 Austin Committee files. It is also possible that magistrates, rather than judges, were chosen for court duty during the bond hearings because magistrates in Chicago are less politically independent than judges. Unlike judges, for example, magistrates are reappointed annually. See text and notes at notes 22-30 supra.

86 ILt. REv. STAt. ch. 38, \& 109-1 (1967).

87 ILl. Const. art. II, § 7; ILL. REV. Stat. ch. 38, § 110-4 (1967); People ex rel. Smith v. Blaylock, 357 III. 23, 191 N.E. 206 (1934).

88 ILl. REv. Stat. ch. 38, § 110-5 (1967).

89 ILl. REv. STAT. ch. 38, § 110(b) (I967).

90 "A person commits disorderly conduct when he knowingly does any act in such unreasonable manner as to alarm or disturb another and to provoke a breach of the peace." ILL. REV. STAT. ch. 38, $\S 26-1(a)(1)$ (1967). "A person convicted of violation of subsection 26-1(a)(1) . . shall be fined not to exceed \$500." ILL. REv. STAT. ch. 38, \$ 26-1(b) (1967).
} 
of his bail with the clerk of the court. ${ }^{91}$ Alternatively, he may secure his bond by offering stocks, bonds, or real estate in the full amount.92 Any sheriff or other peace officer may accept bail set by a judicial officer for a particular offender or offense. ${ }^{93}$

The Code of Criminal Procedure encourages the use of release on recognizance, in lieu of the setting of a cash bond:

When from all the circumstances the court is of the opinion that the accused will appear as required ...., the accused may be released on his own recognizance. ${ }^{94}$

This provision is to be "liberally construed to effectuate the purpose of relying upon criminal sanctions instead of financial loss to assure the appearance of the accused."95

In addition, the Supreme Court of Illinois is authorized by statute to prescribe a uniform schedule of amounts of bail for specified misdemeanor and other cases by rule or order of the court. The $10 \%$ cash deposit provision need not apply to bail amounts established in accordance with uniform schedules for misdemeanors punishable by a fine only. ${ }^{96}$

Pursuant to that authorization the Supreme Court has adopted bail schedules applicable to offenses with which many riot arrestees were charged. Under Rule 528, bail for misdemeanors punishable by fine only "shall be $\$ 50$ cash," except for disorderly conduct, for which bail "shall be $\$ 25$ cash." ${ }^{27}$ The $10 \%$ provision does not apply to these amounts. ${ }^{98}$ Bail for misdemeanors punishable by fine or imprisonment in a penal institution other than the penitentiary, or both, is set at $\$ 1,000$, to which the $10 \%$ provision is applicable. ${ }^{99}$ Any police officer or designated deputy sheriff or circuit court clerk is authorized to accept cash bail under the preset schedules. ${ }^{100}$

The preset bail schedules do not apply to arrests on warrant, or where an offender is brought before a judge. ${ }^{101}$ The schedules were intended to "avoid undue delay in freeing certain offenders when, because of the hour or the circumstances, it is not practicable to bring an

91 ILL. REv. Stat. ch. 38, § 110-7(a) (1967).

02 Id. \& $110-8$.

93 Id. \& $110-9$.

94 Id. \& 110-2.

$95 \mathrm{Id}$.

96 Id. \& 110-15.

97 Id. ch. 110A, \& 528(b) (1967) (Supreme Court Rule 528(b)).

98 Id. § 530 (1967) (Supreme Court Rule 530).

99 Id. §§ 528(c), 530 (1967) (Supreme Court Rules 528(c), 530).

100 ILr. REv. StaT. ch. 16, \& 81 (1967).

101 Ill. ANn. Stat. ch. 110A, note following § 525 (Smith-Hurd 1968). 
offender before a judge."102 Whether or not it is "practicable," under any given circumstances, to bring an offender before a judge is, according to the draftsmen's comments, "a matter of judgment for the arresting officer."103 The defendant always has the right, however, to insist upon being brought before a judge for a bail hearing. ${ }^{104}$

\section{A. Bail Policies During the April Civil Disorder}

The preset bail schedules were not used at any time during the April disorders. Indeed, 35\% of those charged with disorderly conduct (including those arrested for curfew violation) had bail set above \$250. Over half those charged with misdemeanors for which preset bail of $\$ 1,000$ is established by the schedules (resisting arrest, misdemeanors against a person, and misdemeanors against property) had bail set at a higher amount.

The statutory authorization of release on the defendant's own recognizance was initially applied in only one-quarter of the riot arrest cases, although over half of the riot arrestees were charged with a single misdemeanor. And in a few disorderly conduct cases, bail was set above the statutory limit of $\$ 1,000$.

Bail policies during the April riot in Chicago, however, were more lenient than they had been during earlier mass arrest incidents in the city and than they were in cities where riots occurred in the summer of 1967. Bail amounts set for felony arrestees were not higher on the average than they normally are. ${ }^{105}$ In fact, our data indicate that the median bail amount for property felonies (primarily burglary charges) was $\$ 3,830$, compared with a normal average bail of $\$ 4,300$ for burglary. ${ }^{106}$ Median bail for riot property misdemeanors, most of which

102 Id.

103 Id. (Committee comments).

104 ILL. REv. STAT. ch. 16, \& 83 (1967).

105 Comparison with normal bond amounts is hazardous because riot arrestees undoubtedly include a much higher percentage of persons without prior criminal records than normal arrestees.

In 1962, an American Bar Foundation survey found that $78 \%$ of initial bonds in a sample of 249 felony cases were set at $\$ 5,000$ or more, and that $64 \%$ of these bonds remained at $\$ 5,000$ after reduction hearings. Kamin, Bail Administration in Illinois, 53 IrL. B.J. 674,686 (1965). A 1954 survey of 118 felony cases revealed that $75 \%$ of the initial bonds and $52 \%$ of the final bonds were $\$ 5,000$ or more. Kamin, supra at 686 . The Chicago Citizens' Committee for Employment survey of 239 defendants awaiting trial in Cook County Jail in 1964 revealed that $69 \%$ had initial bonds set at $\$ 1,000$ or more. C. O'Reilly \& J. Flanagan, Men in Detention: A Study of Criteria for the Release on RecognizANCE OF PERSONS IN DETENTION 4 (1967). A 1965 survey of 54 persons in jail showed that $74 \%$ had bonds set at $\$ 1,000$ or more. Id. at 7 . It should be noted that the surveys discussed above do not include any persons with recognizance bonds.

106 The Roger Baldwin Foundation of the American Givil Liberties Union, Preliminary Report and Evaluation on the Bail Procedures in Chicago's Looting Cases-Winter, 1967 
were petty theft charges, was $\$ 2,430$, compared with a normal average of $\$ 1,500$ for petty theft. ${ }^{107}$ Higher bail than normal was used for relatively minor misdemeanors. Median bail for arrestees charged with disorderly conduct was $\$ 770$, more than three times the normal amount.108

Data are available on bail policies during seven mass arrest incidents in Chicago in the two years prior to the April 1968 riots. For arrestees from the earliest incidents during the summer of 1966 in the West Side ghetto and the Division Street Puerto Rican community, bail was generally set at $\$ 250$ or $\$ 400$ on misdemeanor charges, and $\$ 5,000$ or $\$ 7,500$ on burglary charges. ${ }^{109}$ Most defendants secured release on bond. 110

By contrast, high bail was utilized in January 1967, when approximately 250 persons, mostly residents of the West Side, were arrested for looting during a crippling snowstorm. According to the American Civil Liberties Union, $10 \%$ bail deposit requirements averaged $\$ 1,400$ in these cases; ${ }^{111}$ the Chicago Daily News reported that bond was $\$ 20,000$ in three-fifths of the cases. ${ }^{112}$ These amounts were substantially higher than those normally set by the Gircuit Municipal Court. Most of those arrested were unable to make bail; many were held in jail for more than three weeks.113 After indictments were obtained, the Criminal Division redetermined bail. Bond was reduced to amounts which most defendants were able to make. One ACLU attorney concluded that, since the same bond rules were applied by the Criminal Division and the Municipal Division, "the inference is clear that the imposition of bail in the first instance was erroneous and excessive."114

In the summer of 1967, a high bail policy was again utilized during four separate incidents on the South Side. During these disturbances, 166 persons were arrested. Their average bail was over $\$ 9,600 ; 38 \%$ were held on $\$ 5,000$ bail, requiring a $\$ 500$ deposit for release. Many were kept in jail for substantial periods before trial, although most of the cases were tried within 10 to 14 days after arrest.

Illinois Special Legal Project 7 (August 1967) [hereinafter cited as ACLU Snowstorm Arrest Study].

107 Id.

108 John Stamos, State's Attorney during the disorders, noted that normal bail for disorderly conduct was $\$ 250$. Austin Committee files.

109 See note 68 supra.

110 Open Meetings Before the Illinois State Advisory Committee to the United States Commission on Civil Rights 173 (June 12, 1968) (testimony of Jay Miller).

111 ACLU Snowstorm Arrest Study 2.

112 Chicago Daily News, February 9, 1967, at 2.

113 ACLU Snowstorm Arrest Study 3.

114 Id. at 4. 
These defendants, it should be noted, were not charged with felonies; for the most part, they were charged with multiple misdemeanors. Nonetheless, the proportion of defendants unable to make bail was as high as the normal rate among felony defendants. Seventy-three per cent of those arrested during the summer incidents never made bond; ${ }^{115}$ in 1962, $75 \%$ of a sample of 231 felony defendants in Cook County were unable to make bond. ${ }^{116}$ In $1964,60 \%$ of a sample of felony defendants did not make bond before trial.117

The Kerner Commission had criticized the use of high bonds in those cities where riots occurred in 1967.118 At the meeting of the National District Attorney's Association in Chicago in February 1968, prosecutors from these cities recommended that bail be set at normal levels during a riot. ${ }^{119}$ The State's Attorney's office in Cook County apparently accepted this advice. After the April riot, the State's Attorney testified that he established limits for bond amount recommendation of $\$ 10,000$ for arson, $\$ 5,000$ for burglary, $\$ 2,500$ for grand theft and serious misdemeanors, and $\$ 1,000$ for state disorderly conduct. ${ }^{120}$

Recommendation of lower bonds than those used in previous mass arrest incidents also reflected local conditions. The Chicago office of the ACLU had severely criticized the earlier high bail policy. In addition, jail facilities were limited; ${ }^{121}$ massive numbers of arrestees could not be detained for long periods, while detention of arrestees for several days during a riot could be obtained without setting bonds so high that they would appear obviously excessive. Despite the statement of one magistrate that $\$ 100$ cash bail today is as easy to put as $\$ 25$ some years ago, ${ }^{122}$ a significant number of riot arrestees had difficulty posting $\$ 100$ cash. In the April riot, unlike earlier mass arrest incidents, prosecutions were for violation of state laws rather than municipal ordinances. ${ }^{123}$ The City of Chicago Corporation Counsel, who nevertheless urged the use of high bail during the April disorders, ${ }^{124}$ had no formal control over the prosecution of riot arrestees. Finally, on March 26 the State's Attorney's office notified police personnel

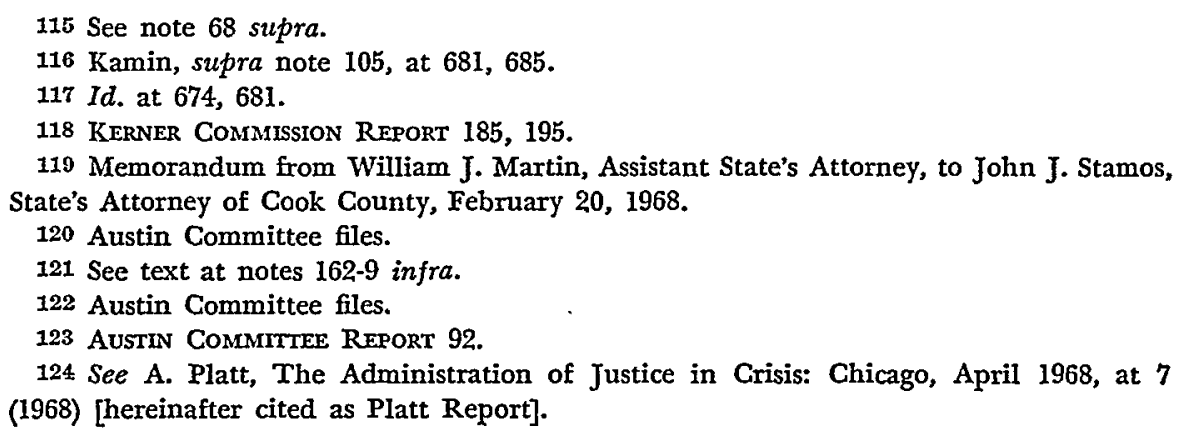


not to use multiple charging which in earlier incidents had been used to justify high bonds. ${ }^{125}$

The effect of the bond policy used during the riot was the temporary detention of many riot arrestees. Bail amounts were set high enough to detain $42 \%$ of those arrested for three days or longer in overcrowded detention facilities. On April 14, almost a week after the riot ended, one-fifth of those arrested remained in custody in Cook County Jail or the City of Chicago House of Correction. ${ }^{126}$ By June 12,60 defendants still were in custody in the County Jail;127 by July 3, 40 remained..$^{128}$

The use of bond amounts for detention is suggested by the remarks of the authorities themselves. An Administrative Assistant in the Cook County Circuit Court stated in a June interview that being held in jail for a week during an emergency "is not such a great tragedy."129 One magistrate in an interview frankly admitted that the "spirit" behind the setting of bonds was one of preventive detention especially during early hours of the riot: "by that I mean to say that the idea was clearly to get as many people off the street as possible." ${ }^{\text {"30 }} \mathrm{An}$ other admitted to being consciously more harsh in setting bonds during the disorders than he would have been in normal circumstances, believing that policy helped "squelch the riots."131 A third magistrate expressly resolved any doubts in favor of higher bond, since people would otherwise go back into the streets. ${ }^{132}$ At least one magistrate, purportedly concerned with the defendant's safety as well as public order, also was expressly less "liberal" than usual in releasing juveniles, especially when no responsible adult relative was present. ${ }^{133}$

One magistrate remarked that high bonds are "exemplary" to people in the neighborhood, and another noted that low bonds or ROR would have "amounted to a mere slap on the wrist." 134 A magistrate who felt that charging minors with state disorderly conduct for violating the Mayor's curfew proclamation was unauthorized, still admittedly detained curfew violators overnight and set $\$ 1,000$ bonds on 41 of

125 Interview with William J. Martin, April 26, 1969.

128 AUSTIN COMMITTEE REPORT 20.

127 Open Meeting Before the Illinois State Advisory Committee to the United States Commission on Civil Rights 207 (June 12, 1968) (testimony of Winston Moore) [hereinafter cited as Moore Testimony].

128 AUSTIN COMMITIEE REPORT note at 20.

129 Austin Committee files.

$130 \mathrm{Id}$.

$131 \mathrm{Id}$.

132 Id.

133 Id.

$134 I d$. 
the 182 curfew defendants he processed. The following is taken from the transcript of one of the bond hearings, for a group or four persons arrested on curfew charges on the evenings of April 7, at which he presided:

The Court: Now, gentleman, I want you to understand I am not conducting a hearing as to the guilt or innocence of the charge which is disorderly conduct based on violation of curfew. This proceeding is solely for the purpose of setting bond so that you may avail yourself of the bond if you can make it. Because of the situation which we have, I am setting a bond of $\$ 1,000$ which means that if you pay $\$ 100$, you can be released on bond, but you will have a hearing tomorrow morning in branch 57.

This violation is based on an order, executive order, which was issued two days ago. There is no reason why you fellows should not have complied with it. It pains me to set a bond of $\$ 1,000$ for you guys because it means that you will have to be in jail until your hearing, but I don't have any choice because of the terrible situation that prevails in our city.

On the afternoon of the 6th, after the special riot curfew had been proclaimed but before it went into effect, Chief Judge Boyle suggested that magistrates release as many curfew violators as possible on their own recognizance. ${ }^{135}$ Seventy-one per cent of the curfew violators were initially released on their own recognizance. However, even those released on recognizance bonds were detained in jail overnight. According to judicial authorities, release at night was impossible because such persons would have been picked up again for curfew violation as soon as they were released.136

Only $8 \%$ of non-curfew arrestees were initially released on ROR. The unwillingness to release these defendants on ROR bonds extended predisposition custody. Ninety-five per cent of those given ROR bonds were released the same day they were arrested or the following day, but over $20 \%$ of those required to put up only $\$ 25$ cash were not released until after they had spent at least two days in jail. Over $85 \%$ of those with bond set over $\$ 250$ spent three or more days in jail before disposition of their case. Table 12 shows that length of predisposition custody varied directly with amount of bond set.

135 AUSTIN COMmitten Report 87. $136 I d$. 
TABLE 12

Length of Predisposition Custody by Amount of Ball Initially Seta

\begin{tabular}{|c|c|c|c|c|c|c|c|c|}
\hline $\begin{array}{l}\text { Predispo- } \\
\text { sition } \\
\text { Custody } \\
\text { (in days) }^{b}\end{array}$ & $\begin{array}{c}\text { Released } \\
\text { Without } \\
\text { Bail }\end{array}$ & $\$ 1-25$ & $\$ 26-50$ & $\$ 51-100$ & $\$ 101-250$ & $\$ 251-500$ & $\begin{array}{l}\text { Over } \\
\$ 500\end{array}$ & Totalo \\
\hline 0.2 & $\begin{array}{l}\% \\
96\end{array}$ & $\begin{array}{l}\% \\
79\end{array}$ & $\begin{array}{l}\% \\
67\end{array}$ & $\begin{array}{l}\% \\
61\end{array}$ & $\begin{array}{l}\% \\
41\end{array}$ & $\begin{array}{l}\% \\
16\end{array}$ & $\begin{array}{r}\% \\
9\end{array}$ & $\begin{array}{c}\% \\
58\end{array}$ \\
\hline $3-10$ & d & 8 & 17 & 21 & 21 & 25 & 26 & 15 \\
\hline $11-30$ & 1 & 6 & 7 & 9 & 18 & 29 & 26 & 13 \\
\hline Over 30 & 2 & 6 & 9 & 9 & 21 & 30 & 39 & 14 \\
\hline & $\overrightarrow{100}$ & $\overline{100}$ & 100 & 100 & 100 & 100 & 100 & 100 \\
\hline $\begin{array}{l}\text { Number of } \\
\text { Cases }\end{array}$ & (494) & (170) & (123) & (406) & (256) & (452) & (54) & (2075) \\
\hline
\end{tabular}

a The actual amount of bail is ten times the indicated cash deposit amount.

$\checkmark$ The length of predisposition custody measures the number of days elapsed between arrest and release. A person arrested at 10 p.m. and released at 2 a.m. is, therefore, credited with one day of custody.

o Includes 120 cases where bond amount information was unavailable.

d Less than $1 / 2$ of $1 \%$.

Even when a defendant had sufficient cash in his possession at the time of arrest to post bail he was denied the opportunity to post it at 11 th and State, where most bond hearings were held. ${ }^{137}$ Instead, he remained in custody until he was transported to the County Jail, where, often many hours later, he was allowed to post bail. ${ }^{138}$ According to judicial personnel, this policy was followed, despite statutory authorization for the clerk of the bond court to receive cash bail, for security reasons. Authorities were convinced that security protection would falter if defendants were released near central police headquarters. ${ }^{139}$

Bail payment procedures were confused. According to the Austin Committee, there was "extensive delay (in some cases amounting to a day or more)"140 between the time when relatives or friends appeared to post bond and the prisoner's release. These delays, it should be noted, do not show up in our data on predisposition custody, which measure only the time from arrest to the posting of bail.

The requirement that many defendants, including a significant number of those charged only with minor offenses, post cash bail caused hardship even for those who did succeed in raising the cash deposit amount. Incarceration as the result of a riot arrest affected the employment of many riot arrestees, if the few we questioned on the subject

\footnotetext{
137 Id.; Platt Report 27.

138 Id.

139 Platt Report 27, 28.

140 AUSTIN Commitiee Report 91.
} 
are a representative sample. ${ }^{141}$ And incarceration during the riot was a harsh form of punishment, as will be seen later in this section.

\section{B. Data on Initial Bail Determination}

Bond amounts for riot arrestees varied with charge, with time of arrest, and with the magistrate who presided at the bail hearing. Of these factors, the seriousness 'of the charge is by far the most important. As Table 13 shows, bond amounts varied widely by charge; those with more serious charges against them were far less often released on their own recognizance and far more often required to post substantial cash bail amounts. Seventy-one per cent of those charged with curfew violation and $20 \%$ of those charged with disorderly conduct were released on their own recognizance, but only $2 \%$ of those arrested on property misdemeanors or felonies and only $4 \%$ of those charged with multiple offenses were so released. Only $4 \%$ of those charged with disorderly conduct had bonds set over $\$ 1,000$, but $65 \%$ of those charged with property misdemeanors, $68 \%$ charged with multiple offenses, and $86 \%$ of those charged with property felonies did.

Of the 504 recognizance bonds, three-fourths were for curfew charges and another $16 \%$ were for disorderly conduct. A majority of the cases in which bond amounts between $\$ 250$ and $\$ 1,000$ were set involved curfew or disorderly conduct charges. Three-fourths of all bonds of $\$ 1,000$ or less were given to curfew and disorderly defendants. On the other hand, with the exception of property misdemeanors, bonds over $\$ 1,000$ were given almost exclusively to those charged with felonies.

As a result, length of detention prior to the disposition of an arrestee's case differed considerably by charge. As Table 14 shows, only $6 \%$ of the curfew arrestees spent four or more days in jail before the disposition of their cases, while $52 \%$ of those arrested for property misdemeanor, and $64 \%$ of those arrested for property felonies spent at least four days in jail before disposition of their cases in the Municipal Division. ${ }^{142}$

Bond amounts were also apparently affected by the extent of riot activity on the streets. ${ }^{143}$ While the patterns are influenced by the policies of particular magistrates who set bail at different periods during the riot, Table 15 suggests that among curfew arrestees bonds were more apt to be used after the peak riot period. Ninety-one per cent of

141 See text at note 450 infra.

142 The data collected may not indicate the full extent of predisposition custody for defendants charged with a felony, since it is likely that those defendants spent considerably more time in jail between the disposition of their cases in the Municipal Division and the final determination of guilt or innocence in the Criminal Division.

143 Austin Comimtree Report 92. 


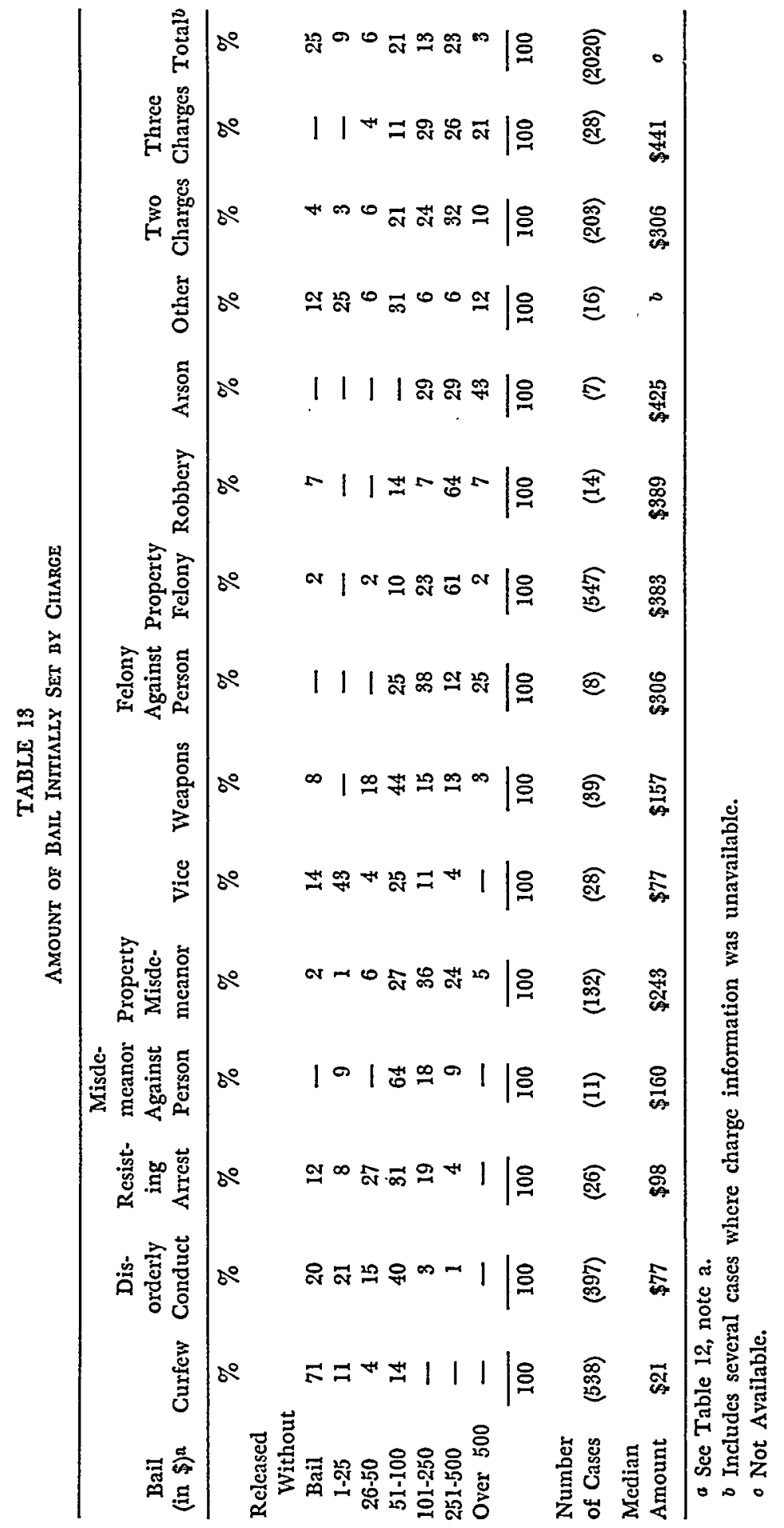


TABLE 14

Length of Predisposition Custody by Charge

\begin{tabular}{|c|c|c|c|c|c|c|}
\hline $\begin{array}{l}\text { Predis- } \\
\text { position } \\
\text { Custody } \\
\text { (in days) }\end{array}$ & Curfew & $\begin{array}{c}\text { Disorderly } \\
\text { Conduct }\end{array}$ & $\begin{array}{c}\text { Property } \\
\text { Misdemeanor }\end{array}$ & $\begin{array}{c}\text { Property } \\
\text { Felony }\end{array}$ & $\begin{array}{c}\text { Multiple } \\
\text { Charges }\end{array}$ & Other \\
\hline & $\%$ & $\%$ & $\%$ & $\%$ & $\%$ & $\%$ \\
\hline $0-3$ & 94 & 76 & 48 & 36 & 39 & 68 \\
\hline $4-10$ & 1 & 12 & 20 & 17 & 19 & 7 \\
\hline $11-30$ & 2 & 7 & 12 & 17 & 21 & 10 \\
\hline Over 30 & 4 & 4 & 19 & 30 & 21 & 15 \\
\hline Total & 100 & $\overline{100}$ & $\overline{100}$ & 100 & $\overline{100}$ & $\overline{100}$ \\
\hline $\begin{array}{c}\text { Number of } \\
\text { Cases }\end{array}$ & $(560)$ & (429) & (130) & $(457)$ & (210) & (136) \\
\hline
\end{tabular}

those arrested for curfew violation on the night of April 6, the first night the emergency curfew went into effect, were required to post cash bond, despite Chief Judge Boyle's suggestion that curfew defendants be released on their own recognizance. On later nights, the proportion dropped sharply; by April 9, only 3\% of the curfew arrestees were not released on their own recognizance. While $23 \%$ of those defendants arrested on curfew charges the first evening the curfew was in effect were detained three or more calendar days before release, the percentage dropped radically on succeeding nights. Variation in bond amounts by time of arrest are less consistent among defendants charged with other offenses. Disorderly conduct defendants arrested on Friday night, however, were more apt to be required to post cash deposits of over $\$ 50$ than disorderly conduct defendants arrested at other periods. Ninety-five per cent of those disorderly conduct defendants arrested on or after Sunday evening, by which time the riot activity had virtually ended, had cash deposit amounts of $\$ 50$ or less.

Our data indicate no significant association between length of predisposition custody and time of arrest among non-curfew arrests. Persons arrested on property felony charges on or after Monday, for example, were more often in custody three or more days than those arrested on Saturday night or Sunday. In large part, such unexpected results probably reflect the activities of bail relief agencies. On April 9 and 10, in particular, the Community Legal Defense Organization made available $\$ 7,000$ in cash for those who remained in detention. ${ }^{144}$

144 The Community Legal Defense Organization was established during the weekend after Dr. King's assassination to raise and distribute bail funds for those arrested. The organization, administered by a coalition of black and white lawyers, students, and com- 
TABLE 15

Bail Status and Lencth of Predisposition Custody of CuRfew ARrestees by Time of ARrest

\begin{tabular}{lcc}
\hline & $\begin{array}{c}\text { Percent Released } \\
\text { Without Bail }\end{array}$ & $\begin{array}{c}\text { Percent Detained } \\
\text { 3 days or more }\end{array}$ \\
\hline $\begin{array}{l}6 \text { pm Saturday- } \\
6 \text { am Sunday } \\
6 \text { pm Sunday- } \\
6 \text { am Monday } \\
6 \text { pm Monday- } \\
6 \text { am Tuesday } \\
\text { After 6 pm Tuesday }\end{array}$ & 83 & 23 \\
\hline
\end{tabular}

Although the money was disbursed according to a set of hardship priorities, with preference given to arrestees who were the sole support of their children, welfare mothers, and the elderly, ${ }^{145}$ a large number of those who benefited from the fund were minor offenders and persons who had already spent significant lengths of time in jail. Given a limited amount of money and the desire to obtain the release of as many persons as possible, there was a natural tendency to post bail first for those with smaller bond amounts.

Several defendants, and the Warden of Cook County Jail, have complained that those arrested late in the riot were "forgotten men."146 Indeed, 51 of the 59 property felony arrestees arrested after 6 p.m. on Sunday who served more than three days of predisposition custody were in jail for over 10 days, and 32 had not made bond by the middle of June, 10 weeks after the riot.

There is little evidence to suggest that the bail policies implemented by the bond hearing magistrates were the direct result of orders from superior judicial officers. ${ }^{147}$ To the contrary, bail policies were, for the most part, the result of recommendations of the State's Attorney and the determinations of individual magistrates. ${ }^{148}$ Partly because of the ineffectiveness of defense counsel (which is the subject of Section VII, infra), the State's Attorney's recommendations were often adopted by the bond courts. And even in instances in which the State's Attorney made no bond recommendation, the uniformity of bond amounts for particular charges was established early.

An analysis of a sample of bond hearing transcripts reveals the sig-

munity leaders, acted as a clearing house for bail information and as a headquarters for bail money contributions. Platt Report 25.

145 Platt Report 25.

146 Moore Testmony 207.

147 Austin Committee files.

148 AUSTIN COMMITTEe REport 92. 
nificant role of the State's Attorney in bond determination. As Table 16 shows, the State's Attorney alone recommended a bond amount in $54 \%$ of the cases. In over three-fifths of these cases, his recommendation was accepted by the presiding magistrate. And in most of the other cases, the magistrate set bond only one category below the State's Attorney's recommendation. ${ }^{149}$ The Public Defender, on the other hand, recommended bond in only $16 \%$ of the cases. This recommendation was accepted in only one-third of these cases; in one-sixth, the amount set was a compromise between his recommendation and the State's Attorney's.

TABLE 16

BAIL RECOMMENDATIONS

\begin{tabular}{|c|c|c|c|c|}
\hline \multirow[b]{2}{*}{$\begin{array}{l}\text { Bail Set at Amount } \\
\text { Recommended by }\end{array}$} & \multicolumn{4}{|c|}{ Recommendation Made by } \\
\hline & $\begin{array}{c}\text { State's } \\
\text { Attorney } \\
\text { Alone }\end{array}$ & $\begin{array}{l}\text { State's Attorney } \\
\text { and } \\
\text { Public Defender }\end{array}$ & Neither & Total \\
\hline State's Attorney & 70 & 15 & - & 85 \\
\hline Public Defender & - & 11 & 一 & 11 \\
\hline Neither & 38 & 5 & 60 & 103 \\
\hline Total & $\begin{array}{c}108 \\
(54 \%)\end{array}$ & $\begin{array}{c}31 \\
(16 \%)\end{array}$ & $\begin{array}{c}60 \\
(30 \%)\end{array}$ & $\begin{array}{c}199 \\
(100 \%)\end{array}$ \\
\hline
\end{tabular}

That the recommendations of counsel-and particularly of the State's Attorney-were adopted in 96 of the 199 cases should not obscure the importance of the individual magistrate's discretion in setting bail. In more than half the cases the magistrates set bail at amounts which had not been recommended by either the State's Attorney or the Public Defender. Table 17 presents data on the amount of bail set by each magistrate for charge categories. The data show wide variations in bond setting practices among the magistrates. Several factors contribute to the variations including the time when a magistrate presided over bail hearings. As indicated earlier, bonds for misdemeanors tended to be set higher early in the riot, as magistrates applied a temporary detention policy. But this factor does not account for all the disparities among magistrates. Even among those sitting at the same time, there were different bond policies. The bond amounts set by some magistrates tend to be clustered around a single category, while those established by other magistrates are distributed over a

149 Thus, in two cases, the State's Attorney recommended $\$ 10,000$ but the magistrate set bond at $\$ 5,000$; in 17 cases, he recommended $\$ 5,000$, but bond was set at $\$ 2,500$; in 3 cases, bond was set at $\$ 500$, despite his recommendation of $\$ 1,000$; and in 4 cases, $\$ 500$ recommendations resulted in $\$ 250$ bonds. 
broader range. Analysis of our sample of 202 bond hearing transcripts suggests that the range of a magistrate's bond determinations reflects the role of the Public Defender in his courtroom. Magistrates like Higgins and Lee, whose bond determinations are clustered for each charge, played a prominent role in examining the defendants in the bond hearings they conducted. (Our sample of bond transcripts included 23 bond cases heard by Higgins and 7 heard by Lee.) On the other hand, the Public Defender did most of the questioning in the hearings conducted by Jankowski and Janega, whose bond determinations tended to range over a number of categories. In hearings conducted by Gorenstein, La Verde, Bailey, and Gill-whose bond determinations for each charge were neither as uniform as Higgins' and Lee's nor ranged as widely as Jankowski's and Janega's-sometimes the Public Defender and sometimes the magistrate did most of the questioning.

The importance of the charge on which the defendant was arrested also varied. Magistrates Lee, Gill, and Gorenstein, for example, set relatively high bonds for defendants in each of the five charge categories. Magistrates Kogut and Janega, on the other hand, were more likely to admit misdemeanor arrestees to relatively low bonds and those charged with felonies and multiple offenses to relatively high bonds. All five of these magistrates sat primarily during the early riot period.

The data examined thus far suggest that individual circumstances were seldom taken into account in setting bond. Active participation of defense counsel in the bond hearing, including the recommendation of an appropriate bond amount, may have had some effect in lowering bond determinations. But defense counsel rarely participated effectively in bond court proceedings. The ineffectiveness of defense counsel, the pressure toward using bail for preventive detention, the failure to utilize preset bail schedules or to operate a sufficient number of bond courts to prevent long delays and crowded dockets, the lack of relevant information about defendants in many cases, and, in general, the demand for judicial economy all contributed to the court's tendency to make non-individualized bail determinations in the vast majority of cases. ${ }^{150}$

150 One major source of delay in bail processing which may have resulted in non-individualized bail hearings was police fingerprinting, photographing, and processing procedures. After April the State's Attorney's office discussed with police department personnel the possibility of avoiding fingerprinting and photographing of minor offenders. Interview with William J. Martin, April 26, 1969. In July $1968 \mathrm{Mr}$. Martin tested a procedure of processing arrestees at the Criminal Court building rather than at district and central police headquarters. But processing time still resulted in long delays. Chicago American, July 24, 1968, at 3; interview with William J. Martin, April 26, 1969. 
TABLE 17

Amount of Bail InItially SeT* by Magistrate for Various Charges

\begin{tabular}{lcccccc}
\hline & \multicolumn{7}{c}{ Curfew } \\
\cline { 2 - 7 } Meleased & $\begin{array}{c}\text { Rewistrate } \\
\text { Without } \\
\text { Bail }\end{array}$ & $\$ 1-25$ & $\$ 26-50$ & $\$ 51-100$ & Over $\$ 100$ & $\begin{array}{c}\text { Number } \\
\text { of Cases } \\
(=100 \%)\end{array}$ \\
\hline Kargman & $\%$ & $\%$ & $\%$ & $\%$ & $\%$ & \\
La Plante & 77 & 1 & - & 23 & - & 182 \\
Edelstein & 99 & - & 1 & - & - & 84 \\
Casey & 99 & - & 1 & - & - & 67 \\
Mooney & 60 & 2 & - & 38 & - & 45 \\
Jankowski & 100 & - & - & - & - & 36 \\
Janega & - & 77 & 13 & 7 & - & 30 \\
Others & 21 & 58 & 21 & - & - & 59 \\
\hline
\end{tabular}

\begin{tabular}{|c|c|c|c|c|c|c|c|c|}
\hline \multirow[b]{2}{*}{ Magistrate } & \multicolumn{8}{|c|}{ Disorderly Conduct } \\
\hline & $\begin{array}{c}\text { Released } \\
\text { Without } \\
\text { Bail }\end{array}$ & $\$ 1-25$ & $\$ 26-50$ & $\$ 51-100$ & $\$ 101-250$ & $\$ 251-500$ & Over $\$ 500 \stackrel{\mathrm{O}}{=}$ & $\begin{array}{l}\text { Number } \\
\text { of Cases } \\
(=100 \%)\end{array}$ \\
\hline & $\%$ & $\%$ & $\%$ & $\%$ & $\%$ & $\%$ & $\%$ & \\
\hline Gill & 5 & 5 & 14 & 76 & - & - & - & 42 \\
\hline Lee & 10 & 3 & 一 & 82 & 5 & - & - & 39 \\
\hline Janega & 12 & 15 & 33 & 21 & 3 & 6 & 9 & 33 \\
\hline Là Plante & 81 & 15 & - & 4 & - & - & 一 & 26 \\
\hline Jankowski & 4 & 21 & 17 & 54 & 4 & - & - & 24 \\
\hline Kogut & 9 & 36 & 27 & 27 & - & - & - & 22 \\
\hline Shamberg & 一 & 14 & 24 & 62 & - & - & - & 21 \\
\hline Gorenstein & 5 & 19 & 5 & 71 & - & - & - & 21 \\
\hline Others & 21 & 26 & 19 & 25 & 5 & 3 & 2 & 129 \\
\hline
\end{tabular}

\begin{tabular}{lcccccccc}
\hline & \multicolumn{7}{c}{ Property Misdemeanor } \\
\cline { 2 - 9 } Magistrate & $\begin{array}{c}\text { Released } \\
\text { Without } \\
\text { Bail }\end{array}$ & $\$ 1-25$ & $\$ 26-50$ & $\$ 51-100$ & $\$ 101-250$ & $\$ 251-500$ & Over $\$ 500$ & $\begin{array}{c}\text { Number } \\
\text { of Cases }\end{array}$ \\
& $=100 \%)$
\end{tabular}


TABLE 17 (Continued)

\begin{tabular}{lcccccccc}
\hline & \multicolumn{8}{c}{ Property Felonies } \\
\cline { 2 - 9 } Meleased \\
Without \\
Wagistrate & Bail & $\$ 1-25$ & $\$ 26-50$ & $\$ 51-100$ & $\$ 101-250$ & $\$ 251-500$ & Over $\$ 500$ & $\begin{array}{c}\text { Number } \\
\text { of Cases } \\
(=100 \%)\end{array}$ \\
\hline & $\%$ & $\%$ & $\%$ & $\%$ & $\%$ & $\%$ & $\%$ & \\
Janega & 1 & - & 3 & 3 & 6 & 81 & 6 & 80 \\
Gill & 3 & 2 & - & 21 & 11 & 63 & - & 62 \\
Gorenstein & 2 & 2 & 2 & 7 & 14 & 72 & 2 & 58 \\
Higgins & - & - & - & 5 & 18 & 77 & - & 39 \\
Kogut & 3 & - & 8 & 18 & 50 & 21 & - & 38 \\
Jankowski & - & - & - & - & 3 & 97 & - & 33 \\
Bailey & 3 & - & - & 34 & 19 & 41 & 3 & 32 \\
Palmer & - & 40 & - & 7 & 29 & 61 & - & 28 \\
Garrity & - & - & - & - & 8 & 69 & 23 & 26 \\
Duggan & - & - & 5 & - & 64 & 32 & - & 22 \\
Others & 4 & - & 2 & 7 & 26 & 58 & 2 & 122 \\
\hline
\end{tabular}

Multiple Charges

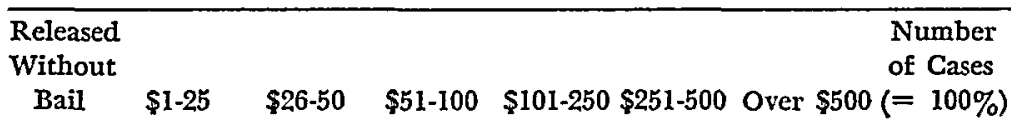

Magistrate Bail $\quad \$ 1-25 \quad \$ 26-50 \quad \$ 51-100 \quad \$ 101-250 \$ 251-500$ Over $\$ 500$ (= $100 \%)$

\begin{tabular}{lrrrrrrrr}
\hline & $\%$ & $\%$ & $\%$ & $\%$ & $\%$ & $\%$ & $\%$ & \\
Garrity & 5 & - & 9 & 23 & 41 & 23 & - & 22 \\
Janega & - & - & 5 & 5 & 25 & 40 & 25 & 20 \\
Gorenstein & - & - & - & 28 & 11 & 50 & 11 & 18 \\
La Plante & 18 & - & 12 & 12 & 35 & 24 & - & 17 \\
Kogut & - & - & - & 6 & 38 & 56 & - & 16 \\
Higgins & - & - & 7 & 21 & 43 & 29 & - & 14 \\
Jankowski & - & - & - & 8 & 42 & 42 & 8 & 12 \\
Limperis & - & - & - & 27 & 18 & 36 & 18 & 11 \\
Others & 16 & 3 & 8 & 19 & 18 & 29 & 18 & 90 \\
\hline
\end{tabular}

* See Table 12, note a.

Illinois statutes do not prescribe specific inquiries which must be made of the defendant in determining bail. Section 110-2, authorizing recognizance bonds, refers to an inquiry into "all the circumstances"; 151 section 110-5 provides that the amount of cash bail shall be "not oppressive," and "considerate of the financial ability" and "the past criminal acts and conduct of the defendant."152 Despite these provisions, the bond hearings seldom included inquiry into the defendant's personal circumstances to determine the likelihood of his subsequent appearance in court. Although magistrates and judicial officers have asserted that relevant information was generally solicited, an analysis

101 III. REv. STAT. ch. 38, § 110-2 (1967).

152 ILL. REV. STAT. ch. 38, § 110-5 (1967). 
of 202 adult bond hearing transcripts does not support their claim. In only $52 \%$ of those cases were questions put to the defendant to elicit information regarding his employment status. In only $26 \%$ were inquiries made regarding the length of defendant's residence in Chicago. Fifty-three per cent of the defendants were asked questions regarding their marital or family status, but only, $26 \%$ were asked concerning their financial ability. And in only $32 \%$ of the cases was inquiry made of the defendant concerning his prior criminal record.

Virtually none of this information was available to the magistrate from other sources, including police records. Prior criminal history sheets, normally referred to for purposes of bond setting, were unavailable. ${ }^{153}$ Public Defenders, especially early in the riot, were not permitted to interview defendants in the bullpen prior to the hearing in order to obtain information. ${ }^{15 *}$ Volunteer lawyers were rarely successful in obtaining relevant information concerning the defendants which could be introduced at the hearing, ${ }^{155}$ and no standardized means of verifying privately obtained information was instituted. ${ }^{156}$ In addition, overcrowded temporary detention facilities annexed to the bond courts resulted in many defendants being processed through bond hearings in groups of up to four arrestees. ${ }^{157}$

The summary character of most bond hearings is best reflected in the transcripts. The following excerpts are representative:

The Defendant:

The Court:
I'd like to have a break because I got burned out Saturday because I have no clothes and nothing but what I gots on and my kids the same thing and nowhere to stay. All I got is one lousy five dollars. Well, look, these are difficult times for a lot of people, and a lot of people are getting themselves into trouble. All $I$ know is the charge that has been filed against you and

\footnotetext{
153 AUstin Commitre REPoRT 90. One magistrate said that it would have meant "too much delay" to consider any prior criminal history sheets in the bailsetting process, and that consequently he released no defendants on their own recognizance. Austin Committee files.

154 Platt Report 7-8.

155 One magistrate noted that he did not allow lawyers to talk to clients until their cases were called, because it would have been "too slow" to permit such consultation. Austin Committee files.

156 Austin Committee files.

157 AUSTIN COMMITTEe REPORT 89. One magistrate noted that the large volume of cases in the bond courts made it "almost impossible" to hold complete bond hearings, and that the idea was to process cases "as fast as possible," so people who had money could get out of jail quickly. Austin Committee files.
} 
based on the charge I can't make that less than $\$ 5,000$. I wish I could . . . .

The Clerk:

[Announcing the case]

The State's Attorney: State curfew, your honor.

The Court:

What were you doing on the corner?

Defendant:

Going home.

The Court:

From where?

Defendant:

From a friend's house.

The Court:

Thousand dollar bond, April 18th.

The Glerk:

[Announcing the case]

The Court:

What were you doing on 63rd and Ellis?

Defendant:

I was there with a friend of mine at the

The Court: Company.

These are riotous conditions going on, get off the street. 11:00 o'clock at night.

Defendant: It wasn't 11:00 o'clock.

The Court:

Bond, thousand dollars, branch 47, April 18th.

The Clerk:

[Calling the defendant]

The State's Attorney: [He] is charged with resisting arrest and obstructing a police officer, who was attempting to effect an arrest. We suggest the 16th of April and a $\$ 1,000$ bond.

The Court:

So ordered, 4/16/68, $\$ 1,000$ bond, Branch 47 ....

The State's Attorney: In the matter of the bond, since the defendant is not pleading guilty, the State recommends a bond of $\$ 5,000$. Court date of April 18th.

Private Attorney: $\quad$ I would like to ask the Court to reconsider his bond on three grounds. [Presenting employment, residence, and family information].

The State's Attorney: . . The State remains steadfast that the bond be retained at $\$ 5,000$ until the time of trial.

The Court: ... The change [burglary] is an extremely serious charge. In the absence of unimpeach- 
Private Attorney: Your Honor, may I point out that the purable evidence of the facts stated the Court is not inclined to lower the bond. pose of bond is to insure presence. They have families and are employed in the City and are residents in the community. That should be an important factor in consideration of setting bond.

The Court: $\quad$ The Court denies the request of counsel for the defendants.

The Clerk:

[Calling defendant]

The Court:

[Reading the charge] How do you plead?

Defendant:

Not guilty.

The Court:

State's Attorney.

The State's Attorney:

The Court:

Is it a theft charge, your Honor?

Theft charge.

The State's Attorney: The Court is asking the State for a bond?

The Court:

The State's Attorney: The Court is asking the State for a recommendation.

The Court:

The State's Attorney:

The Court:

We recommend a bond of $\$ 1,000$, on a charge of theft.

This is burglary.

$\$ 5,000$, your Honor.

The Court accepts the State's recommendation and sets bond at $\$ 5,000$. Plea of not guilty. Order of Court.

Private Attorney: Your Honor, the defendant states he has no record. He has been working for Wash for the past eight months.

The Court: You say the defendant has no record. Where do you get your information, just from his statement?

Public Defender: $\quad$ Yes, sir, that is all.

The Court:

The Clerk:

The Court:

The bond will remain at $\$ 5,000$.

[Calling defendant]

$[\mathrm{Y}]$ ou have been charged by that on or about the 6th of April, 1968, at 2310 West Roosevelt, you committed the offense of disorderly conduct in violation of Chap- 
ter 28, Section 26-1(a)(1). Let the record show that a plea of not guilty has been entered in arraignment. Bond will be set at $\$ 1,000$.

It is important to emphasize that relevant individual inquiry for the purposes of setting bond was made in many cases. But even in these cases there is no indication that the information was taken into account. The magistrate often set bonds at the amount recommended by the State's Attorney in these cases, as excerpts from bond hearing transcripts show:

The Court:

The State's Attorney: I recommend $\$ 5,000$ bond on the charges of

Public Defender:

The Court:

Defendant:

The Court:

Defendant:

The Court:

Defendant:

The Court:

Defendant:

The Court:

Defendant:

The Court:

Defendant:

The Court:

Defendant:

The Court:

Defendant:

The Court:

Defendant:

The Court:

The Glerk:

The Court:

Defendant:

[Calling defendant]

burglary and disorderly, your Honor.

I request a lower bond. This man does work, and I don't know what his record is. How long have you lived in Chicago?

I have been here about, I'd say nine years or more.

Married?

Yes.

Do you have any kids?

About five.

The kids and wife live with you?

Yes.

Does your wife work?

She don't work.

Have you been employed?

Employed?

Are you working?

Oh yes. I am working.

Where are you working?

Work for — Auto Wash, where they wash cars.

How long have you worked there?

Four or five years or more.

Five thousand dollar bond.

[Calling defendant]

How long have you lived in Chicago?

Eleven years. 
The Court:

Defendant:

The Court:

Defendant:

The Court:

Defendant:

The Court:

Defendant:

The Court:

The State's Attorney:

The Court:

The Clerk:

The State's Attorney:

Public Defender:

Defendant:

Public Defender:

Defendant:

Public Defender:

Defendant:

Public Defender:

Defendant:

Public Defender:

The Glerk:

The State's Attorney:

Defendant:

Public Defender:
Are you married?

Yes.

Any children?

Four.

What time of the day was this?

I guess it was about two in the morning.

Do you work for yourself?

Yes-not exactly, but I am with another guy.

We do decorating.

What is the recommendation.

My information indicates a 3:30 a.m. time, and the charge is burglary. Recommend $\$ 5,000$ bond.

Five thousand dollar bond.

[Calling defendant]

Your Honor, Mr. _ is also charged with burglary ...

Tell the Judge. You have a job?

Yes.

How long have you been working?

Two years.

Are you married?

Yes, I am.

Do you have any children?

Yes, one. Your Honor, as far as I am concerned, I got a good job. I just got my job. I am making good money. My wife, she is sick. She got cramps from taking these birthcontrol pills, and she can't work. I don't want to be put in jail because I haven't got any money-I don't want to lose my home and job or nothing.

We request $\$ 1,000$ bond.

What time was the arrest?

Twenty-five after twelve this morning, inside the premises, where obviously he did not belong.

No, I wasn't. Sir, I want-

Is he going to show up for trial? Let's show the fact that he is trying to keep the job. 
Defendant:

The Gourt:

Defendant:

The State's Attorney:

The Court:

The Glerk:

Public Defender:

Defendant:

Public Defender:

Defendant:

Public Defender:

Defendant:

The Court:

Defendant:

The State's Attorney:

The Court:

Public Defender:

Defendant:

Public Defender:

Defendant:

Public Defender:

Defendant:

Public Defender:

Defendant:

Public Defender:

Defendant:

Public Defender:

Defendant:

Public Defender:

Defendant:

The State's Attorney:

Public Defender:

Defendant:

Public Defender:
I don't want to lose my job and my home. I will lose everything if I don't go to work.

Is your wife working?

No, she can't work. She is under the doctor.

I suggest if he is so concerned about his wife and home, he would have been there. Five thousand dollars bond.

[Calling defendant, arrested for burglary]

The defendant states he is working.

I was just getting off from work.

How long have you been working there?

For the last three years, sir. . . .

Do you have a family?

Sure, a wife and three kids. I have two jobs.

What were you doing in this building?

I was not in the building, Judge ...

The State recommends bond for $\$ 5,000$, court date of April 18th.

Bond, $\$ 5,000$.

How old are you, Donald?

Eighteen.

Where do you live?

[Answering]

Who do you live with?

My mother and father.

How long have you lived at that address?

Eight years.

Do you work or do you go to school?

I go to school.

What school?

High School.

What year are you in?

I am a senior.

We recommend a $\$ 1,500$ bond, Judge.

How much money can you raise for bond? I don't know, $\$ 75$ or $\$ 100$.

Your Honor, we wrould ask the bond be set at $\$ 500$. 
The Court:

The Glerk:

Public Defender:

Defendant:

Public Defender:

Defendant:

Public Defender:

Defendant:

Public Defender:

Defendant:

Public Defender:

Defendant:

Public Defender:

Defendant:

The Court:

Public Defender:

The Court:

The State's Attorney: [Recommends $\$ 5,000$ bond on a burglary

The Court:

Public Defender:

Defendant:

Public Defender:

Defendant: defendant]

The bond will be set at $\$ 1,500$ for appearance in Branch 47 on April 18th, $\$ 150$ cash we will release you. ...

[Calling defendant, arrested for violation of curfew]

Are you married or single?

I am married.

And how many children do you have?

I have three children.

Where do you work?

I work for the Post Office and also a barber part-time. . . .

And where do you live?

[Answering]

How long have you lived at that address?

I lived there about ten years.

And how long have you worked for the Post Office?

Five years.

Your bond will be $\$ 500$ for an appearance. Your Honor, could you make that an individual bond? This is simply another curfew situation. No other aggravation.

He lives at - He was arrested at — where we had an awful lot of trouble. That's all. ...

What is the story here?

Judge, he's been employed at the Company for a year and a half, he has been a resident of Chicago for ten years. -..

I have to go to work tomorrow, I have kids to support.

How many children do you have to support, Dave?

Two. 
The Court:

Defendant:

The Court:

Defendant:

The State's Attorney:

The Court:

Defendant:

The Court:
Twenty-five hundred dollar bond. . . .

Your Honor, can you drop the bond, I can't raise that much today.

What bond could you make?

I can raise a hundred dollars.

I resist that.

I dropped it to twenty-five hundred dollars.

I can't raise that.

I can't help you, sir, if you can't raise it. I set the bond, I didn't get you in trouble, you understand that. That will be the order.

The sample of bond hearing transcripts, taken as a whole, shows no significant relationship between bond amount and information on marital and employment status, number of children, length of residence in Chicago, and number of prior arrests, where this information was elicited. ${ }^{158}$ Data from the entire sample of 2,189 riot cases generally support this conclusion. Controlling for charge we compared bond amounts among those with and without prior arrest or conviction records, and among the employed, unemployed, and students-factors presumably relevant to bail determinations. As Tables 18 and 19 indicate, there is no substantial variation in the distribution of bond amounts by these variables.

\section{G. Detention Facilities}

We have already noted that preset bail schedules, which would have enabled many defendants to post cash bail without appearing in court, were not used during the riot. ${ }^{159}$ During the first days of the riot, no procedure was instituted to enable defendants to post bail immediately after their bail hearings. ${ }^{160}$ Even curfew defendants released on their own recognizance were detained overnight at the City House of Correction, the County Jail, or temporary detention facilities. ${ }^{161}$ Almost all defendants spent some time in jail; those unable to make bail were often detained for long periods.

Although the State's Attorney's Riot Control Unit had considered the use of other detention facilities in mass arrest situations-including the State Penitentiary at Joliet-only the Gity House of Correction

\footnotetext{
158 These data confirm the Austin Committee's finding: "There is no question that there was little individual variation in the setting of the bonds." Austrin Commrrree REPORT 92.

159 See text at notes 96-104 supra.

160 Platt Report 27.

161 Austin CoMmittee Report 87.
} 


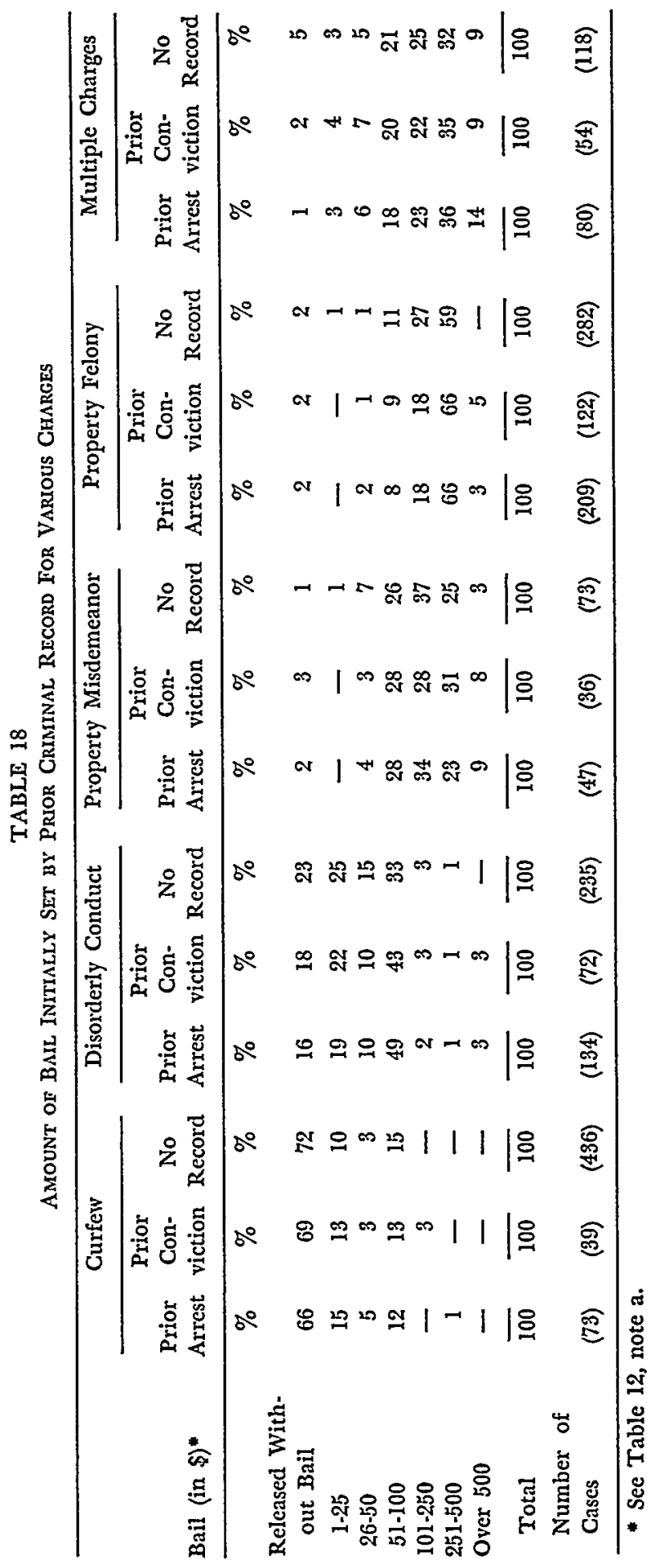




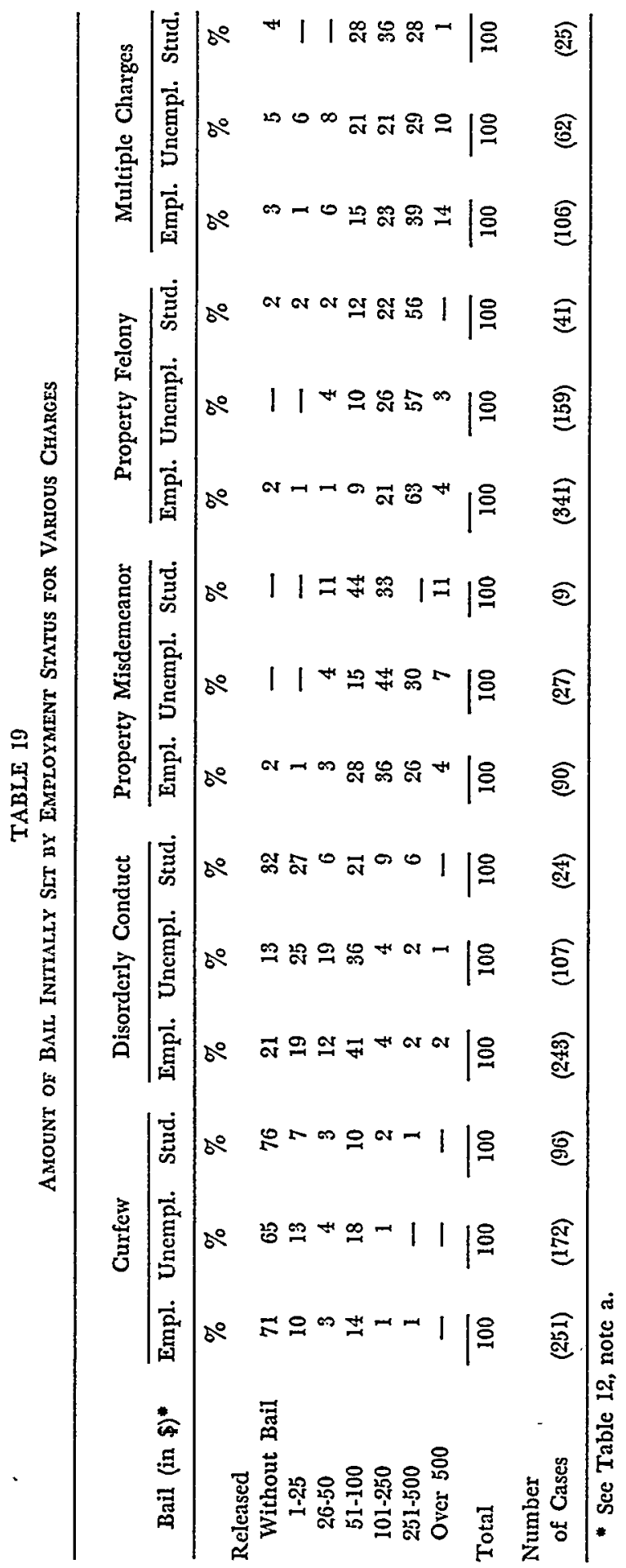


and the County Jail were used during the April riot. ${ }^{162}$ At the height of the riot, a number of convicted misdemeanants who had served over half their sentences were pardoned to make room for riot arrestees in the House of Correction. ${ }^{163}$ Conditions at the House of Correction were somewhat better during the riot than at the County Jail, but were not beyond criticism. ${ }^{164}$

The County Jail, a maximum security institution for detention of both convicted prisoners and those awaiting trial, was designed to hold 1,302 males. ${ }^{165}$ On March 31, its inmate population was $1,881,44 \%$ above its capacity. ${ }^{166}$ During the riot, an additional 800 prisoners were sent to the County Jail, because facilities at the House of Correction were inadequate. ${ }^{167}$ Riot arrestees were segregated from other inmates at the jail, both to avoid placing them with indicted felons and convicted misdemeanants and because many were not processed prior to assignment to a cell. ${ }^{168}$ The jail tiers, which are designed to accommodate 39 men and normally house 70 , held as many as 200 prisoners during the riot. ${ }^{160}$

The jail, under an administration which had been in office for only three weeks, had no emergency plan for the processing of large numbers of prisoners. ${ }^{170}$ Some 400 prisoners arrived during one 18 hour period, as compared with normal daily admissions of 50 to 60.171 The normal jail staff was not augmented during the riot, although some staff members did work overtime to process riot arrestees. ${ }^{172}$ The result was

162 Id.

163 Interview of Superintendent C. William Ruddell, House of Correction, with Isaac Balbus, January 10, 1969: "One further step that $I$ took with the cooperation of the circuit court and the Corporation Counsel ... we made the decision at my request to discharge all prisoners from here who had no more than 10 days left on their sentence, and who had served at least half their sentence. Approximately 270 were discharged."

The release occurred on Monday, April 8. According to $\mathrm{Mr}$. Balbus, there were two main factors involved in the decision. First, the curfew was still in effect, and therefore more arrests were expected. Second, some officials apparently feared renewed disorders on the South and West Sides on Tuesday, the day of Dr. King's funeral.

164 Austin Commitee Report 108.

165 H. Mattick, The Cook County Jail: Report of Cook County's Correctional Plant and Program 9 (1957) (prepared while the author was Assistant Superintendent, Cook County Jail).

166 Sheriff's Report of Prisoners in the Cook County Jail (Report of All Prisoners in the Custody of the Sheriff of Cook County Jail, March 31, 1968, pursuant to InL. REv. STAT. ch. 75, § 8).

167 Moore Testimony 212.

168 Id. at 204-5.

169 Id. at 204.

$170 \mathrm{Id}$. at 203.

171 Austin Commrtree Report 108.

172 Platt Report, app. F; Austin Committee files. 
chaotic; records, and even prisoners, were lost. ${ }^{173}$ Some arrestees were under 17 years of age and, once admitted, were unable to secure release without court order. ${ }^{174}$ According to the testimony of the Warden, "lots of them [prisoners] were lost"; "everything broke down."175

As prisoners entered the jail, there were insufficient temporary detention facilities. The jail bullpen, which normally accommodates 50 men awaiting medical processing, often held over $200 .^{176}$ Only two doctors were available to conduct medical examinations. ${ }^{177}$ Many prisoners were not permitted to shower before final processing. ${ }^{178}$ Cells which normally house two prisoners held as many as five prisoners. ${ }^{179}$ According to the chief guard, there were shortages of mattresses, bedding and blankets. ${ }^{180}$ Many prisoners slept on bare floors in the dayrooms of the tiers. ${ }^{181}$ Toilet facilities were inadequate. ${ }^{182}$ The daily diet of many prisoners consisted of two bologna sandwiches. ${ }^{183}$ And, because the County Jail and the House of Correction could not accommodate the large number of arrestees, many prisoners were held in the Criminal Court lockup "for a long time under extremely crowded conditions with no food."184

Many prisoners were admitted to the jail with improper or incomplete mittimus papers and this impeded processing and identification. ${ }^{185}$ Upon admission, prisoners were given identification cards and photographs were taken.186 However, by the time photographs were developed, a number of prisoners had apparently traded their identification cards for cigarettes. ${ }^{187}$ A limited use of aliases further complicated identification. ${ }^{188}$ The problem was aggravated by what several

173 Moore Testimony 202, 212.

$174 I d$. at $211-2$.

$175 I d$. at $205,215$.

176 AUSTIN COMMITTEE REPORT 106.

177 Id.

$178 \mathrm{Id}$.

$179 \mathrm{Id}$. at 107.

180 Austin Committee files.

181 AUSTIN COMMITTEE REPORT 108.

182 Moore Testimony 207.

183 Austin Committee files; see also Austin Commitre Report 107; Platt Report 28.

184 BrIEF app. D, p. 4 (May 1968).

185 Moore Testimony 215.

186 AUSTIN CoMmitTeE REPORT 107.

187 Austin Committee files.

188 AUSTIN COMMITTEE REPORT 107. Warden Moore has estimated that "maybe about five per cent, maybe more" of arrestees sent to the Cook County Jail used aliases. Moore Testimony 212. Data taken from police arrest sheets of 2,047 arrestees show that the police recorded existence, rather than the use, of an alias in less than $2 \%$ of the cases.

Another report noted "[w]e have no way of knowing how many people did give false names but there were many specific instances when a correct name was found three days 
observers referred to as lackadaisical attitude on the part of jail employees. ${ }^{188}$

Under Illinois law, an arrestee has the right to communicate with an attorney or a member of his family "by making a reasonable number of telephone calls or in any other reasonable manner."190 If he is transferred to a new place of custody, his right to communicate is renewed. ${ }^{191}$ The County Jail, however, is not equipped with telephones for the use of prisoners. ${ }^{192}$ Defendants who were unable to make telephone calls prior to incarceration had to rely on the services of volunteers or helpful jail personnel. ${ }^{193}$ And often prisoners were not assigned to a detention facility until their arrival, which prevented them from notifying an attorney or their families of their location. ${ }^{194}$ Recordkeeping breakdowns made it impossible for relatives to locate prisoners for hours and even days. ${ }^{195}$ Despite long lines of inquiring friends and relatives, the records window at the County Jail was closed at night without explanation. ${ }^{106}$ There was no coordination between the records department and the bond clerks or between the jail and House of Correction lists. ${ }^{197}$

Volunteers, including lawyers, were able to track down some prisoners and relay information to friends and relatives. ${ }^{198}$ They also acted as court clerks, expanding incomplete records to obtain information needed to post bond for a prisoner. ${ }^{199}$ Persons who arrived to post bond sometimes waited as long as two days after payment of bail before prisoners were released. ${ }^{200}$

The Kerner Commission's recommendation that "[d]uring any detention period, defense counsel must be able to interview prisoners individually at the detention centers" went unheeded ${ }^{201}$ during the week after Dr. King's assassination. Public Defenders and volunteer lawyers were often turned away from the jail. ${ }^{202}$

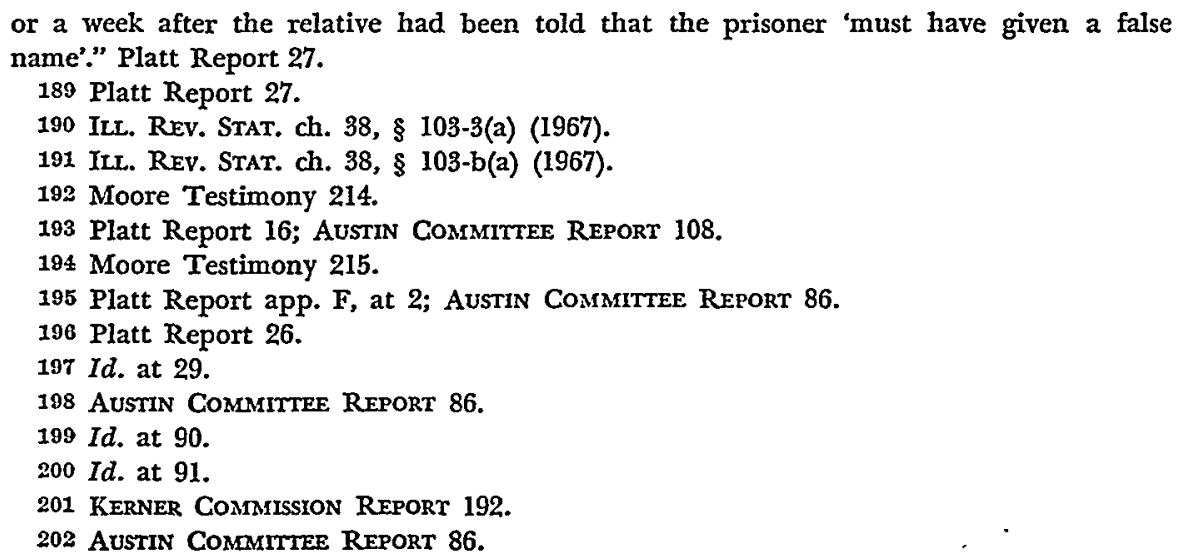


The impact of bail policies on riot arrestees, their relatives, and their friends cannot be fully appreciated without recognition of the hardship of detention under these conditions. Defendants whom we interviewed described their detention in vivid and bitter terms:

We were in the cell, no mattresses, no bed, no anything, five in a cell, no nothing. You know we get to know each other so good that we took turns sleeping. . . . You would have to, you know, take turns sleeping or else you just didn't sleep.

We got one sandwich a day, and if we got smart we didn't get that. ... The guards would come in there, and if you so much as asked a little question, they'd just spray mace on you. That stuff you just can't breathe. ...

After I got in jail I didn't trust anyone even if they came and said they were a lawyer and wanted to help. We just couldn't trust them.

Like living in a slum building. Every where it was dirty, nasty, smelled like piss and looked like piss. It's enough to make you sick.

They should have at least put me in a clean cell or something. I mean I don't think that you should have put all of us in one room like a bunch of animals with everyone laying on top of one another and everyone needin' a bath and stinkin' in there. And see how they was sweatin'. And ya have to get in the bathroom and go to the window before you could get any air, and at least about twelve guys in the little ole bathroom trying to get to the window.... That's the way they treated us, I mean, just like a bunch of animals.

Well, to me they were like a cowpen where you put cows in, where you put this cow and this cow in this pen, and this cow and this cow in this pen. Only in this case there were a whole lot of cows in this pen, and a whole lot of cows in this pen. It was like on a farm, and the way you would treat animals, ... I mean, you treat dogs better.

Like a chain gang. It was overcrowded, you didn't have a place to sleep, you had to sleep in shifts, you had to wash up in shifts, you cleaned yourself in the best way you could. 


\section{Bond Reduction Hearings}

The non-individualized bond amounts set at initial bond hearings and the continued detention of a large proportion of riot arrestees in overcrowded and unsanitary facilities, generated public pressure to institute bond reduction procedures.

On Monday, April 8, about 40 lawyers met under the auspices of the Chicago Bar Association (CBA) and decided that the president of the Association should attempt to get more courts opened to hold bond hearings. ${ }^{203}$ Later the same day, the president and vice president of the CBA met with Judge Boyle, without informing or inviting any representatives of the volunteer or legal aid organizations. ${ }^{204}$ After the meeting they informed other lawyers that bond reduction hearings would begin on Wednesday, April $10 .^{205}$ Chief Judge Boyle argued that no bond reduction hearings should take place on Tuesday because Dr. King's funeral could cause new tension in the black community, which might be exploited by those making bail as a result of bond reduction..$^{206}$

No bond reduction hearings were held on Wednesday, contrary to what the CBA and several volunteer lawyers had been led to believe. ${ }^{207}$ On Wednesday evening, the Cook County Bar Association (CCBA), whose membership consists of black lawyers from the Chicago area, met to discuss the role of black lawyers in defending riot arrestees. ${ }^{208}$ The Association sent a telegram to Chief Judge Boyle informing him that representatives of the Cook County Bar would be at his office the next day. ${ }^{209}$ Over 50 members appeared for the meeting, along with reporters. ${ }^{210}$ After initially refusing to meet with all of the Cook County Bar members present, Judge Boyle met briefly with the group. ${ }^{211}$

Mayor Daley had declared the emergency to be over on Wednesday, and lifted the curfew. ${ }^{212}$ Chief Judge Boyle, who opposed any bond reduction hearings until such a determination had been made by the executive, ${ }^{213}$ apparently gave his assistants permission to hold bond

203 Platt Report 10. Another estimate said there were only 20 lawyers present. See Open Meeting Before the Illinois State Advisory Committee to the United States Commission on Civil Rights 50, June 12, 1968 (Testimony of Lawrence X. Puseteri) [hereinafter cited as Puseteri Testimony].

204 Platt Report 10.

$205 I d$.

206 Id.

207 Id.

$208 \mathrm{Id}$. at 11.

209 Austin CoMmitien Report 93; Platt Report 11.

210 AUSTIN COMMITTEE REPORT 93.

211 Id.; Platt Report 12.

212 Austin Commitee Report 93.

213 Id, at 95 . 
reduction hearings on Thursday. ${ }^{214}$ At about the same time the Cook County Bar group was attempting to meet with Chief Judge Boyle, the vice president of the CBA and a representative of the ACLU were told that bond reduction hearings would begin later in the day. ${ }^{215}$ Only one magistrate was sitting, however, and the flow of cases was irregu$\operatorname{lar}^{216}$ because the court was requiring a written petition for each individual requesting a reduction hearing ${ }^{217}$ and the State's Attorney had announced that one day's notice was necessary to allow the State's Attorney's office time to locate the prisoner and his prior arrest record. ${ }^{218}$ Both these requirements were intended to assure the court and the State that each arrestee's file would be available, so that his arrest record could be taken into account. According to Anthony Platt, "It was extremely difficult for the attorneys to comply with this standard procedure under emergency conditions because the Jail and the House were unable to handle the expanded population and could not or would not supply the lawyers with the names of the prisoners."210 The Austin Committee asserts that the State's Attorney cooperated with volunteer attorneys in the location of prisoners:

The assistant state's attorneys, upon receiving a call from a volunteer lawyer that he intended to obtain a bond reduction hearing for a particular defendant, would call the jail and have the prisoner brought over to the court. The assistant state's attorneys would then search through the unorganized pile of arrest history sheets ... in order to locate that particular man's history and report. ${ }^{220}$

It appears that about a maximum of 100 persons-most likely those represented by private attorneys-obtained bond reduction hearings by the 11 th. ${ }^{221}$ But at least 600 arrestees still remained in jail..$^{222} \mathrm{Few}$ reduction hearings were conducted on the 12 th and 13 th, ${ }^{223}$ primarily

214 Id. at 87,94 .

215 Platt Report 10.

216 Puseteri Testimony 51-52.

217 AUSTIN COMMrTTEe REPORT 87; Puseteri Testimony 59.

218 Interview with William J. Martin, April 26, 1969; IrL. REv. STAT. ch. 38, § 110-6(b) (1967) requires that "reasonable notice" of an application for a bond reduction be given to the State. In the Criminal Division of the Circuit Court of Cook County, notice of motion to reduce bail must be served on the State's Attorney, and filed with the Clerk of the Criminal Court before 2 p.m. of the day preceding the hearing of the motion. Circuit Court of Cook County, Criminal Division, Rule 5, §ई 2, 4(a).

219 Platt Report 11.

220 Austin CoMmitteE Report 98.

221 Id. at 94.

222 Austin Committee files; accord, Address by Judge Boyle to members of the Cook County Bar Association, April 11, 1968.

223 Austin Committee Report 94. 
because few defense counsel had requested bond reduction hearings in specific cases. ${ }^{224}$ The ex-Chairman of the CBA's Committee on Givil Disorders testified that on the 13th the State's Attorney told him he would insist on written notice of proposed bond reduction hearings. ${ }^{225}$ Members of the CBA photostated arrest records and presented them to the State's Attorney: "[W]e made that our written notice."226 In addition, a mandamus action was filed on the 12th by four volunteer attorneys to compel the Chief Judge to provide the necessary facilities for special bond reduction courts over Easter weekend. ${ }^{227}$ Further conferences involving private attorneys and members of the CBA and CCBA were held on the 13th..$^{228}$

On Easter Sunday, the 14th, nine special bond courts were opened in the Criminal Court Building and House of Correction at 26th and California. ${ }^{229}$ About 275 defendants, represented by the Public Defender or volunteer attorneys, had bond reduction hearings on that day. ${ }^{230}$ At least 90 more bond reduction hearings were held on the 15th and 16th. In all, over 500 bond reduction hearings were conducted for riot defendants.

According to the Administrative Assistant to the Chief Judge, plans to open bond reduction courts as soon as the riot had subsided were initiated by the Court and were not stimulated by pressure from the GCBA or other private attorneys. ${ }^{231}$ There is substantial evidence that those still in custody when the riot ended would have been afforded an opportunity to have their bonds reduced. It is unlikely, however, that nine courtrooms would have been opened to facilitate bond reduction hearings without the demands by both black and white attorneys, as well as the State's Attorney. 232

224 After April 1968 the Circuit Court established procedures for review of bonds "[a]s soon as practicable" after the mass arrest incident on the motion of the court. General Order of the Circuit Court of Cook County No. 18 (1968).

225 Puseteri Testimony 59.

$226 I d$. There is some evidence however that the State's Attorney waived requirement of written notice, although exactly when is unclear. See Austin Commitrer RePort 94. Under normal circumstances written notice is usually waived. Boyle, Bail Under the Judicial Article, 17 DE PAul L. Rev. 267, 274 (1968).

227 Austin Commitre Report 94; Memorandum from Phillip H. Ginsberg, Mandel Legal Aid Clinic, to National Legal Aid and Defender Association, at 7, May 9, 1968 [hereinafter cited as Ginsberg Memorandum].

228 Ginsberg Memorandum 8.

229 Puseteri Testimony 60; Platt Report 14.

230 The Chicago Sun-Times, in an article entitled Riot Suspects Win Freedom For Easter, reported that there were 283 bond reduction hearings held on Easter Sunday. Chicago Sun-Times, April 15, 1968, at 5.

231 Austin Committee files.

232 The State's Attorney hoped to alleviate overcrowded detention facility conditions and avoid the necessity of conducting bond reduction hearings during the following week when riot cases were scheduled for trial. Interview with William J. Martin, April 26, 1969. 
Over $70 \%$ of the bond reduction hearings were conducted on or after Easter Sunday, a week after the rioting had subsided. Many of those arrested early in the riot who had been unable to make bail had been in detention for a week before their bond was reviewed. The delay in bail review was contrary to the normal practice, as described by the Chief Judge in early 1968:

As soon as it is determined by court records that the defendant is being held pending trial for failure to post bond, an assistant Public Defender interviews him to determine his suitability for a release upon individual recognizance. ${ }^{233}$

We obtained data on 496 arrestees who had bond reduction hearings. Persons who had bond reduction hearings were more likely to have prior arrest and conviction records than arrestees who did not have bond reduction hearings. That fact probably reflects the greater incidence of prior criminal records among persons charged with serious offenses. As we have previously noted above, defendants charged with relatively serious offenses had higher bail amounts, resulting in greater likelihood of a bond reduction hearing, than arrestees charged with minor offenses. (See Table 18.) Nearly half of the persons who had bond reduction hearings were arrested on felony charges, as compared with approximately one-fifth of those who did not have reduction hearings. Only one-fourth of the former group were charged with curfew violation or disorderly conduct as compared with over half of other arrestees.

Of those defendants who had bond reduction hearings $85 \%$ had their bond reduced. Over one-quarter were released on their own recognizance and another three-eighths had their bond reduced to an amount which required a cash deposit of $\$ 100$ or less to obtain release.

The results of bond reduction hearings are tabulated in Table 20. Two patterns emerge-release of those with initial money bonds requiring a cash deposit of $\$ 100$ or less on their own recognizance and reduction of bonds requiring a deposit of more that $\$ 100$. Eighty per cent of those whose initial bonds were $\$ 1,000$ or less were given ROR's; they accounted for $86 \%$ of the defendants released on their own recognizance after bond reduction hearings. Nearly two-fifths of the defendants with initial bonds higher than $\$ 1,000$ had them reduced to that amount; only $15 \%$ had them reduced to a lower amount. The presence of those reduction patterns suggest that magistrates at bond reduction hearings were in many cases using original bail amounts as 
guidelines to determine the limits of bond reduction. In some cases, the same magistrate presided over the reduction hearing as had set the initial bail; 234 several have admitted that they were reluctant to lower bonds they had personally set.235

\section{TABLE 20}

AMIOUNT OF Final BaIl BY AMOUNT OF INITLAx BaIl FoR Riot ARrestees Having Bond Reduction HeARings

\begin{tabular}{|c|c|c|c|c|c|c|c|c|c|c|c|c|}
\hline \multirow{3}{*}{$\begin{array}{c}\text { Final Bail } \\
\text { Amount } \\
\text { (in } \$ \text { ) } a\end{array}$} & \multicolumn{12}{|c|}{ Initial Bail Amount (in \$) } \\
\hline & \multicolumn{2}{|c|}{$1-25$} & \multicolumn{2}{|c|}{$26-50$} & \multicolumn{2}{|c|}{$50-100$} & \multicolumn{2}{|c|}{$101-250$} & \multicolumn{2}{|c|}{$251-500$} & \multicolumn{2}{|c|}{ Over 500} \\
\hline & $\begin{array}{l}\text { Num- } \\
\text { ber }\end{array}$ & $\%$ & $\begin{array}{c}\text { Num- } \\
\text { ber }\end{array}$ & $\%$ & $\begin{array}{c}\text { Num- } \\
\text { ber }\end{array}$ & $\%$ & $\begin{array}{c}\text { Num- } \\
\text { ber }\end{array}$ & $\%$ & $\begin{array}{l}\text { Num- } \\
\text { ber }\end{array}$ & $\%$ & $\begin{array}{c}\text { Num- } \\
\text { ber }\end{array}$ & $\%$ \\
\hline \multicolumn{13}{|l|}{ Released } \\
\hline Without Bail & (12) & 86 & (7) & 64 & (88) & 81 & (4) & 7 & (12) & 5 & (1) & 3 \\
\hline $1-25$ & $(2)^{b}$ & 14 & (1) & 9 & (7) & 6 & (1) & 2 & - & - & - & - \\
\hline $26-50$ & & & $(3)^{b}$ & 27 & (6) & 6 & (12) & 20 & (22) & 9 & (1) & $\mathbf{3}$ \\
\hline $51-100$ & & & & & $(7)^{b}$ & 6 & (25) & 41 & (108) & 43 & (5) & 15 \\
\hline $101-250$ & & & & & & & $(19)^{b}$ & 31 & (72) & 28 & (7) & 21 \\
\hline $251-500$ & & & & & & & & & $(39)^{b}$ & 15 & (8) & 24 \\
\hline \multirow[t]{2}{*}{ Over 500} & & & & & & & & & & & (12) & 35 \\
\hline & (14) & 100 & (11) & 100 & (108) & 100 & (61) & 100 & (253) & 100 & (34) & 100 \\
\hline
\end{tabular}

a See Table 12 , note a.

$b$ Bonds in these categories may have been reduced within the category.

The results of bond reduction hearings differed considerably by charge. The Austin Committee found that magistrates considered whether a "serious hard core" case was involved in making reduction determinations. ${ }^{236}$ Defendants who did not fall within this group, the Committee suggests, were released on their own recognizance or had bond redetermined at an amount "within their resources."237

Our data suggest that only if "serious, hard core" is taken to mean all riot arrestees except those charged with curfew violation and disorderly conduct is the Austin Committee's finding accurate. Ninetenths of those charged with curfew who had reduction hearings obtained release on their own recognizance as did two-thirds of those charged with disorderly conduct. In all, nearly seven-eighths of those charged with either of these two offenses obtained ROR's or could achieve release by posting $\$ 25$. But well over half of those charged with other offenses, misdemeanor or felony, had bonds reset at $\$ 1,000$ or more. (See Table 21.)

234 AUSTIN COMMITtee Report 95.

235 Austin Committee files.

236 Austin Committe Report 96.

237 Id. 
TABLE 21

Bond Reduction Hearing Results for Vartous Charges

\begin{tabular}{|c|c|c|c|c|c|c|}
\hline $\begin{array}{l}\text { Final Bail } \\
\text { Amount } \\
\text { (in \$)* }\end{array}$ & $\begin{array}{l}\text { Initial Bail } \\
\text { Amount } \\
\text { (in \$) }\end{array}$ & Curfew & $\begin{array}{l}\text { Disor- } \\
\text { derly } \\
\text { Conduct }\end{array}$ & $\begin{array}{l}\text { Property } \\
\text { Misd. }\end{array}$ & $\begin{array}{c}\text { Property } \\
\text { Felony }\end{array}$ & $\begin{array}{c}\text { Multiple } \\
\text { Charges }\end{array}$ \\
\hline \multirow{8}{*}{$\begin{array}{l}\text { Release } \\
\text { Without Bail }\end{array}$} & & $\%$ & $\%$ & $\%$ & $\%$ & $\%$ \\
\hline & & 88 & 67 & 2 & 4 & 11 \\
\hline & $1-25$ & 10 & 2 & - & - & - \\
\hline & $26-50$ & 6 & 2 & - & - & - \\
\hline & $51-100$ & 72 & 55 & - & - & 5 \\
\hline & $101-250$ & 一 & 4 & 2 & - & 2 \\
\hline & $251-500$ & - & 2 & 一 & 3 & 5 \\
\hline & Over 500 & - & 2 & - & 一 & - \\
\hline \multirow[t]{7}{*}{$1-25$} & & 一 & 16 & 2 & - & 2 \\
\hline & $1-25$ & - & 4 & - & - & 一 \\
\hline & 26.50 & - & 2 & 一 & - & 一 \\
\hline & $51-100$ & - & 10 & 2 & - & 2 \\
\hline & $101-250$ & 一 & 一 & - & - & - \\
\hline & $251-500$ & - & - & 一 & - & - \\
\hline & Over 500 & - & - & - & - & - \\
\hline \multirow[t]{6}{*}{$26-50$} & & $I$ & 6 & 32 & 9 & 9 \\
\hline & $26-50$ & 一 & 6 & - & - & - \\
\hline & $51-100$ & 1 & 一 & 7 & $\rightarrow$ & 3 \\
\hline & $101-250$ & - & - & 2 & 3 & 5 \\
\hline & $251-500$ & - & - & 20 & 5 & 2 \\
\hline & Over 500 & - & 一 & 2 & - & - \\
\hline \multirow{5}{*}{$51-100$} & & - & 6 & 32 & 45 & 25 \\
\hline & $51-100$ & - & 4 & 5 & - & - \\
\hline & $101-250$ & - & - & 5 & 8 & 5 \\
\hline & $250-500$ & - & 2 & 20 & 36 & 17 \\
\hline & Over 500 & - & - & 2 & 1 & $\mathbf{3}$ \\
\hline \multirow[t]{4}{*}{$101-250$} & & - & 2 & 27 & 27 & 23 \\
\hline & $101-250$ & - & 2 & 15 & 3 & 5 \\
\hline & $251-500$ & - & - & 12 & 24 & II \\
\hline & Over 500 & - & - & 一 & - & 8 \\
\hline \multirow[t]{3}{*}{$251-500$} & & - & - & - & 13 & 17 \\
\hline & $251-500$ & - & 一 & - & 12 & 9 \\
\hline & Over 500 & - & - & - & 1 & 8 \\
\hline \multirow[t]{2}{*}{ Over 500} & & - & - & 5 & 1 & 8 \\
\hline & Over 500 & - & - & 5 & 1 & 8 \\
\hline \multirow[t]{2}{*}{ Increase } & & 9 & 2 & 1 & 1 & 6 \\
\hline & & 100 & 100 & 100 & 100 & 100 \\
\hline \multirow{2}{*}{$\begin{array}{l}\text { Number of } \\
\text { Cases }\end{array}$} & & & & & & \\
\hline & & (78) & (49) & (41) & (244) & (65) \\
\hline
\end{tabular}

- See Table 12, note a. 
The Austin Committee also suggested that " $[w]$ here the charge was not serious and the arrestee had no serious criminal record," judges at reduction hearings "were inclined to release the arrestee on his own recognizance or to set the bond at whatever amount the arrestee could make." ${ }^{238}$ For curfew and disorderly conduct cases, the fact that the charge was minor seemed to be sufficient to achieve this result; the presence of an arrest or conviction record made little difference. The availability of prior criminal records at bond reduction hearings does seem to have had an impact on magistrates' determinations for defendants charged with other offenses. Those with a prior record were less likely to have bond reduced to ROR, and, except for property misdemeanants, defendants were less likely to have bonds reduced to amounts requiring a cash deposit of $\$ 100$ or less. ${ }^{239}$

The Austin Committee's indication that one relevant criterion for resetting bail was the defendant's ability to pay does not seem to be borne out by the data. Even comparatively small cash deposit requirements sometimes prevented a defendant from obtaining release prior to trial. ${ }^{240}$ Thirty per cent of those who had bond reduction hearings did not make bail, and $13 \%$ of those whose final cash deposit amount after bond reduction hearing was $\$ 100$ or less did not make bail. Less than $6 \%$ of those charged with curfew or disorderly conduct were not released after their bond reduction hearings, but $39 \%$ of those charged with all other offenses did not make bond. Of those who had a money bond set after reduction hearings, two-fifths failed to make bond; $96 \%$ of those defendants were charged with offenses other than curfew and disorderly. These data also seem to cast doubt on the Cook

238 Id. at 94.

239 We also tabulated the results of reduction hearings by employment status; no clear pattern emerges. The employed obtained proportionately more ROR's among defendants charged with disorderly conduct, but the unemployed obtained proportionately more ROR's among property misdemeanor arrestees. On the other hand, unemployed property misdemeanor defendants more often ended up with bonds over $\$ 1,000$. The reduction hearings led to similar results for employed and unemployed property felony defendants, but students fared better than either of these groups, more often achieving bond reduction to $\$ 1,000$ or less.

240 The Austin Committee noted that even $\$ 100$ cash is "a high amount for those who are poverty stricken." AUSTIN COMMMTTEE REPORT 91. It is noteworthy that, of the defendants for whom we have information concerning bond reduction hearings, $33 \%$ had cash bonds of $\$ 100$ or more after those hearings. It is difficult to reconcile this fact with the Austin Committee's apparent approval of the bond reduction hearings in which "\$5,000 bonds were reduced to $\$ 1,000$ or $\$ 1,500 . "$ Id. at 94 . Presumably, the Committee felt that $\$ 100$ cash was an appropriate bond for people who had been in detention for a week on more serious charges, but was not acceptable for defendants arrested for disorderly conduct at the early part of the disorder. 
County State's Attorney's assertion that reduction in bond was usually "to the limit that the defendant could make."241

There may have been several reasons for a defendant's inability to make bond after a reduction hearing. As we suggested earlier in this section, some magistrates at bond reduction hearings may have shown inadequate awareness of the financial plight of many of the defendants before them. ${ }^{242}$ Some were reluctant to reduce bonds they had set. Conversely, some defendants may have overestimated the resources available to get them out of jail. ${ }^{243}$ There are conflicting evaluations of the quality of bond reduction hearings, ${ }^{244}$ but it is clear that more than one-quarter of those defendants who came before the magistrates to have bond reduced did not get out of jail before the disposition of their cases in the Municipal Court system.

Twenty-four per cent of the total number of riot arrestees who were not released on their own recognizance-and $17 \%$ of those whose cases were not disposed of at their bail hearing-were not able to obtain their release on bond prior to the final disposition of their cases. Over half of these defendants were charged with property felonies, and nearly one-fifth with more than one offense. But only $9 \%$ of the curfew arrestees and $11 \%$ of the disorderly conduct arrestees who had money bond set were unable to obtain their release before trial. Thirty-three per cent of the property felony defendants, $31 \%$ of those charged with multiple offenses, and $22 \%$ of the property misdemeanor defendants could not raise enough cash to meet their deposit requirement.

More important, over half those not making a final cash bond never had a bond reduction hearing. ${ }^{245}$ And among those who did

241 In fact, one observer has suggested that magistrates were reducing bond "to an amount that was just over that which the defendant stated he could make." Platt Report 31.

242 See text at note 122 supra.

243 In a telephone conversation on April 1, 1969, Melvin Goldberg, an attorney present at some of the bond reduction hearings, noted that in some instances magistrates set bond at amounts that defendants agreed they could raise. Some of these defendants subsequently failed to obtain pretrial release because friends or relatives could not, or did not, raise the necessary amount of money.

244 Platt Report 31; Austin Committee Report 94-95.

245 Data on the characteristics of those not making bond show that, both for those who had bond reduction hearings and those who did not, those with a previous criminal record and the unemployed were generally less likely to make bond. This probably reflects the fact that those with prior criminal records were more often arrested on serious charges, for which higher bonds were set, and that the unemployed had less resources available for bond. 
make bail a surprisingly small percentage forfeited bail by not appearing at a subsequent court appearance. ${ }^{246}$

\section{E. Conclusion}

In this section, we have analyzed bail determinations during the April disorder. We found that the bail policy used did not include the setting of unusually high money bonds. In fact, felony bonds for riot arrestees were set near normal levels. Misdemeanor bonds were set above normal amounts, but not as high as those used in earlier civil disorders in other cities, or in previous mass arrest situations in Chicago. The result of the bail determinations, however, was the detention of many arrestees for extended periods of time. A significant number had difficulty raising even relatively moderate cash bail; those able to make bail were denied early release because of chaotic bail posting procedures.

It is important to recognize that detention overnight, for a day, or for two days was the almost inevitable result of a massive influx of arrestees into unprepared jail facilities. Detention was prolonged by inefficient clerical processing in the courts, jails, and police stations. But there is also evidence that some magistrates were setting cash bail for the express purpose of detaining riot arrestees, particularly during the first days of the disorder. Unusually high bond amounts were not needed to effectuate preventive detention. A large proportion of normal arrestees are unable to make bail; in the chaotic conditions of a riot, it could be predicted that an even larger proportion would not make cash bail, at whatever level it was set, especially when they were unable to communicate with their families, friends, or attorneys. The use of near normal bail amounts may have reflected an understanding by the State's Attorney and the Circuit Court that the detention of riot arrestees could be effectively achieved without utilizing obviously excessive bail determinations, such as those which had been criticized in Detroit and elsewhere.

Initial bail determinations were non-individualized in most cases, based only on the charge against the arrestee. Uniformity in bailsetting is not restricted to times of civil disorder. As early as 1927, one study of bail in Chicago found:

246 Our data show that $6 \%$ of a sample of 1,191 adult arrestees forfeited money bonds before disposition of their cases in the municipal court system. In many cases, this forfeiture judgment was vacated in accordance with Illinois law. ILI. REv. STAT. ch. 38, § 110 7 (1967). Interestingly, $6 \%$ of a sample of 599 defendants who were given recognizance bonds also forfeited bond.

These figures compare favorably with normal forfeiture rates. Chief Judge Boyle has written that the forfeiture rate for "ten per cent" bonds in Municipal Division One was $10 \%$ in 1965 , and $11 \%$ in 1966. Boyle, supra note 226, at 275. 
[T] here are certain standard amounts of bail for specific offenses. For instance, in the Municipal Court the rule and practice is that for a single violation of any section of the city code, the bail is fixed at $\$ 400$. In the case of "disorderly conduct," for instance, the standard amount is set down by the clerk, more or less automatically, and irrespective of the facts in the case, the character and reputation of the accused, etc. In the Griminal Court, exactly the same policy obtains. For each charge or indictment for burglary, bail is fixed at $\$ 5,000$. In the case of robbery, bail is $\$ 10,000$ for each indictment, and so on. ${ }^{247}$

The Cook County court system has been reorganized since 1927; bond amounts have changed; the $10 \%$ cash deposit provision has superseded the bondsman. But the substitution of fixed bail amounts for individualized determinations, which the early study criticized, is still apparent. As the transcripts of bond hearings suggest, it was accentuated during the riot.

The uniformity of initial bail determinations during the riot, and the resulting detention of many arrestees in deplorable conditions, produced demands from the bar for bond reduction hearings. But these hearings were not held in substantial numbers until the 14th, four days after the emergency was officially declared over, a result, in part at least, of the failure of defense attorneys to request specific bond reduction hearings earlier and the reluctance of the court to institute such proceedings on its own motion.

The result of bond reduction hearings, as our data show, was the release of some defendants on their own recognizance and bond amount reduction, but not necessarily release, for most of the rest. After the riot had ended, the courts no longer seemed interested in continued detention of those arrested during the riot for misdemeanors, especially curfew violation and disorderly conduct. Those detained for more serious offenses, however, were often unable to make their new bonds. In particular, the court seemed reluctant to set bonds at levels which those with prior criminal records could meet.

No strictly comparable data on normal arrestees are available. What data we have suggest that a roughly equal proportion of riot felony arrestees and normal felony defendants did not make bail. But riot arrestees were younger and it may be assumed, poorer than those normally arrested. Accordingly, we may speculate that the prominence of riot cases resulted, to some degree, in special treatment of them, at 
least after the riot was over. The court achieved its initial goal of detaining riot arrestees during the disorder. Once the riot had ended, it appears to have returned to its normal bail practices in both felony and misdemeanor cases. 


\section{The Disposition of Riot Cases}

Some $54 \%$ of the riot arrestees charged with a misdemeanor were ultimately convicted in the Municipal Department. Nearly $70 \%$ of the riot felons whose cases were disposed of in the Criminal Division by February 28, 1969, were also convicted. And one-third of those charged with multiple offenses during the riot were convicted of at least one misdemeanor in the Municipal Department. ${ }^{248}$

The ultimate judicial determination of guilt in these cases, however, resulted in less severe sanctions than those normally imposed by the criminal courts. Seventy per cent of the riot felons convicted by early 1969 were sentenced only to probation. Over $90 \%$ of the convicted misdemeanants were fined, and over half of these were fined less than $\$ 15$. A majority of those fined never had to pay the amount stipulated; they were credited instead with having worked off their fines on the basis of the time they had spent in custody prior to trial. For those defendants-primarily those charged with minor misdemeanors -conviction and sentencing were almost a mere formality. Our data show, for example, that nearly all the convicted disorderly conduct defendants were sentenced to a fine of $\$ 50$ or less and that for a majority pretrial detention time equalled or exceeded the fine amount (computed at the rate of $\$ 5$ per day). Many of these defendants, who were allowed to credit their detention time to their fine, fared no worse than defendants who were not convicted. About half of the curfew and disorderly conduct defendants and over three-fifths of the property misdemeanor defendants who spent three or more days in pretrial detention were ultimately discharged or dismissed. Thus, the punishment imposed by the criminal justice system was borne by many defendants before, not after, trial, and it was borne without regard to whether there was final judgment of guilt.

The courts did ultimately make judgments concerning guilt and sentencing, and their impact cannot be disregarded. In this section we consider those factors which are related to the ultimate disposition of riot cases. Two types of factors may be identified, although they are not mutually exclusive. The first includes the individual characteristics

248 This figure is somewhat misleading since some defendants were charged with multiple felonies, or a combination of felonies and misdemeanors. The Municipal Department, as was indicated in Section $I$, has no jurisdiction to hear felony cases, and the final judgment of that department for such cases is normally "nolle prosequi" or "held to the grand jury." Of those charged with two misdemeanors, $47 \%$ were convicted of at least one. 
of defendants-age, prior criminal record, and employment status. The second includes systemic factors, relating to the operation of the criminal justice system-the charge filed against, a defendant, when he was arrested, his ability to obtain release on bond, the length of his predisposition custody, the date on which his case was disposed of by the court, and the magistrate presiding over the disposition of his case. ${ }^{249}$ We shall examine these factors as they influenced the defendant's plea, the final judgment entered in his case, and his sentence if he was convicted. Our data relate primarily to the disposition of cases in the Municipal Department. At the time we obtained records on individual cases, few of the riot felony cases had been disposed of by the Criminal Division. Although we have limited aggregate data on those which were completed prior to February 28, 1969, we have no detailed data for individual defendants beyond the Municipal Department. The data on the preliminary disposition of these cases in the Municipal Department and available data on disposition in the Criminal Division are presented later in this section. First, however, we consider the disposition of misdemeanor cases, for which our statistical information is more exhaustive.

\section{A. Misdemeanor Cases}

1. Disposition: The Nature of the Charge. For defendants charged with single misdemeanors, the seriousness of the offense significantly influenced the ultimate disposition of the case. (See Table 22.) Threefifths of those charged with curfew violation, and half of those charged with disorderly conduct and resisting arrest were found guilty. By contrast, two-fifths of those few defendants charged with misdemeanors against the person and less than one-third of those charged with property misdemeanors were convicted. Just as those charged with more serious offenses were less apt to be convicted, they were more likely to be dismissed before trial. Three-fifths of the cases against those charged with personal and property misdemeanors were dismissed, but only one-quarter of the curfew, resisting arrest, and disorderly conduct cases were dismissed. Discharges upon a finding of not guilty do not follow such a simple pattern; they were relatively rare for personal and property misdemeanor cases, but not so infrequent for the other offenses.

There are several possible explanations for these figures. A prima facie case is relatively easily established by the prosecution for the less serious offenses; it generally requires only the testimony of the arresting officer, unlike personal and property misdemeanors. In addi-

249 Another systemic factor-the role of defense counsel-is the subject of Section VIf. 
TABLE 22

DispostrION OF GASES

\begin{tabular}{|c|c|c|c|c|c|c|}
\hline \multirow[b]{2}{*}{ Disposition } & \multirow[b]{2}{*}{$\begin{array}{c}\text { Curfew } \\
\%\end{array}$} & \multicolumn{5}{|c|}{ Misdemeanor } \\
\hline & & $\begin{array}{c}\text { Disorderly } \\
\text { Conduct } \\
\%\end{array}$ & $\begin{array}{c}\text { Resisting } \\
\text { Arrest } \\
\%\end{array}$ & $\begin{array}{c}\text { Against } \\
\text { Person } \\
\%\end{array}$ & $\begin{array}{c}\text { Property } \\
\text { Misdemeanor } \\
\%\end{array}$ & $\begin{array}{c}\text { Total } \\
\%\end{array}$ \\
\hline Dismissed & 17 & 36 & 31 & 60 & 62 & 30 \\
\hline Discharged & 23 & 12 & 19 & - & 8 & 17 \\
\hline Convicted & 61 & 51 & 50 & 40 & 30 & 53 \\
\hline No. of cases & $\begin{array}{c}\overline{100} \\
(575)\end{array}$ & $\begin{array}{c}100 \\
(445)\end{array}$ & $\begin{array}{c}\overline{100} \\
(32)\end{array}$ & $\begin{array}{l}100 \\
(10)\end{array}$ & $\begin{array}{c}100 \\
(135)\end{array}$ & $\begin{array}{r}100 \\
(1197)\end{array}$ \\
\hline
\end{tabular}

tion, since in Illinois a state case can be dismissed prior to trial in any of four ways, ${ }^{260}$ data on dismissal as a single category tend to obscure the subtle differences in the disposition of the cases within the three largest misdemeanor charge categories.

In the discussion below we will consider, for the most part, only three misdemeanor charge categories-curfew, disorderly conduct, and property misdemeanor. These three charge groups encompass the entire

TABLE 23

TyPe of DISMISSAL

\begin{tabular}{lccc}
\hline $\begin{array}{c}\text { Type of } \\
\text { Dismissal* }\end{array}$ & $\begin{array}{c}\text { Curfew } \\
\%\end{array}$ & $\begin{array}{c}\text { Disorderly } \\
\text { Conduct } \\
\%\end{array}$ & $\begin{array}{c}\text { Property } \\
\text { Misdemeanor } \\
\%\end{array}$ \\
\hline DWP & 4 & 30 & 19 \\
SOL & 47 & 30 & 50 \\
Nolle prosequi & 20 & 28 & 31 \\
LFD & 29 & 13 & - \\
\cline { 2 - 4 } Number of cases & 100 & 100 & 100 \\
& $(96)$ & $(162)$ & $(84)$ \\
\hline
\end{tabular}

* See note 250 , supra.

spectrum of misdemeanor charges in terms of seriousness; they also constitute $96 \%$ of the single-charge misdemeanor cases in our sample. And because, as we have seen, the charge is the key variable in dis-

250 There are four forms of dismissal in Cook County. L.F.D. or "leave to file denied" indicates that a magistrate, normally at a bail or preliminary hearing, has decided that the charges against the defendant should not be entertained in the courts. S.O.L. or "stricken off with leave to reinstate" represents the prosecution's agreement to drop charges with the right to reinstate such charges within four months. In ordinary practice, an S.O.L. is usually tantamount to a final dismissal. D.W.P. or "dismissed for want of prosecution" usually indicates the absence of an identifiable complainant or arresting officer. Nolle prosequi serves as a general category of dismissal used when no other notation is appropriate. Nolle prosequi of a felony charge in the Criminal Division usually indicates that the charge has been dropped in favor of a guilty plea to a reduced charge. 
position (as it is in sentencing), we will consider the data for each charge category independently.

With the exception of LFD, it is difficult to determine whether the court or the State's Attorney initiated a dismissal. LFD represents a magisterial decision to dismiss the complaint at the initial court appearance. At times it is used in cases where a night in jail is considered sufficient to achieve the purpose of the charge. It is probably accurate to say that other forms of dismissal are in the overwhelming majority of cases initiated by the prosecution. As Table 23 shows, three-tenths of the curfew dismissals and one-eighth of the disorderly conduct dismissals were LFD's. By contrast, none of the property misdemeanor cases was dismissed by use of an LFD order. It is clear that magistrates were screening curfew violators and disorderly conduct defendants out of the criminal justice system at bail hearings, but not property misdemeanor arrestees. Furthermore, it is possible to speculate, on the basis of the data for other dismissal types, that more dismissals of property misdemeanor cases than of the other two charges were initiated by the prosecution. This probably reflects the greater difficulty the State's Attorney had in assembling evidence for a prima facie case where a property misdemeanor charge was involved.

The data on discharges and convictions for these charges also mask important differences among them. Twenty-six per cent of the curfew defendants pleaded guilty compared to $16 \%$ of those charged with disorderly conduct and of those charged with property misdemeanors, suggesting that relatively lenient sentences imposed in curfew cases, as well as the ease of proving a curfew violation, induced many defendants to plead guilty. But Table 24 shows, somewhat surprisingly, that only three-fifths of those actually tried for curfew violations were convicted. The explanation for this is probably the policy of some magistrates to acquit curfew defendants who had been detained during the riot, rather than convict and sentence them to time already served. ${ }^{251}$

Riot curfew and disorderly conduct charges are offenses for which there are no counterparts during normal times. The ordinary disorderly conduct case usually involves drunkenness, vagrancy, or a domestic dispute. It would, therefore, be misleading to compare the disposition of all riot misdemeanors with the disposition of an ordinary sample of misdemeanors. But the other riot misdemeanors-misdemeanors against the person and against property, resisting arrest, and the handful of miscellaneous charges-may usefully be compared

251 Data presented later in this chapter on disposition by magistrate serve to illustrate this point. See Table 42 infra. 
TABLE 24

Disposition of Cases Going to Trial

\begin{tabular}{lccc}
\hline Disposition & $\begin{array}{c}\text { Curfew } \\
\%\end{array}$ & $\begin{array}{c}\text { Disorderly } \\
\text { Conduct } \\
\%\end{array}$ & $\begin{array}{c}\text { Property } \\
\text { Misdemeanor } \\
\%\end{array}$ \\
\hline Convicted & 60 & 74 & 62 \\
Acquitted & 40 & 26 & $\frac{38}{100}$ \\
Number of cases & 100 & 100 & $(29)$ \\
\hline
\end{tabular}

with a normal sample. If we exclude curfew and disorderly conduct cases from the riot misdemeanors, we find that $34 \%$ of the misdemeanor defendants were convicted. This is very similar to the conviction rate for all misdemeanor cases decided in Chicago in 1963, the last year for which comparable data are available. ${ }^{262}$ In that year, $37 \%$ of the misdemeanor defendants were convicted. ${ }^{253}$ As we shall later see, the type of sentence imposed in these two groups of cases was also similar. This suggests that, with the exception of curfew and disorderly conduct cases, riot charges were not disposed of significantly differently from normal misdemeanors; the differences occurred prior to final disposition and involved bond (and consequent detention for many) rather than the ultimate decisions in the case.

The conviction rate for the April riot cases differed substantially from that for defendants arrested during the minor mass disturbances in 1967. Seventy per cent of those arrested in the 1967 incidents were ultimately convicted of at least one offense, ${ }^{254} 17 \%$ more than the percentage of single-charge misdemeanants convicted after the 1968 riot. The 1967 defendants were booked on multiple charges; bail, as noted earlier, ${ }^{255}$ was set unusually high; and the majority of the arrestees spent long periods in custody before trial. As a result, over three-fifths of these defendants pleaded guilty to at least one charge.

2. Disposition: Personal Factors. We turn now to considerations of those personal factors which may have had an impact on the likelihood of conviction. We have not attempted to make a particularly sophisticated analysis of those factors which might have influenced disposition. Our data limit us to consideration of only a few-prior criminal record, age, and employment status. We find that, for all

252 In 1964, after the reorganization of the Cook County Circuit Court, official statistics in misdemeanor and quasi-crime (municipal ordinance) dispositions were combined so that it is no longer possible to get independent data on misdemeanors.

253 Oaks \& Lehman 39, Table 7.

254 See note 68 supra.

255 See text at note 115 supra. 
charge categories except curfew, those with prior arrest records were much more apt to be convicted than those who had not been previously arrested. (See Table 25.)

TABLE 25

Conviction Rates by Prior ARrest Record

\begin{tabular}{|c|c|c|c|c|}
\hline & \multicolumn{2}{|c|}{ Curfew } & \multicolumn{2}{|c|}{ Disorderly Conduct } \\
\hline & Convicted & $\begin{array}{l}\text { Number } \\
\text { of Cases }\end{array}$ & Convicted & $\begin{array}{l}\text { Number } \\
\text { of Cases }\end{array}$ \\
\hline No prior arrest record & $61 \%$ & (493) & $46 \%$ & $\overline{(303)}$ \\
\hline \multirow[t]{4}{*}{ Prior arrests } & $57 \%$ & $(82)$ & \multicolumn{2}{|c|}{$\begin{array}{l}63 \% \text { (142) } \\
\text { Misdemeanors }\end{array}$} \\
\hline & \multirow{2}{*}{\multicolumn{2}{|c|}{ Resisting Arrest }} & \multirow{2}{*}{\multicolumn{2}{|c|}{$\begin{array}{l}\text { Misdemeanors } \\
\text { Against Person }\end{array}$}} \\
\hline & & & & \\
\hline & Convicted & $\begin{array}{l}\text { Number } \\
\text { of Cases }\end{array}$ & Convicted & $\begin{array}{l}\text { Number } \\
\text { of Cases }\end{array}$ \\
\hline No prior arrest record & $38 \%$ & (21) & $33 \%$ & (9) \\
\hline \multirow[t]{3}{*}{ Prior arrests } & $73 \%$ & (11) & $100 \%$ & \\
\hline & \multicolumn{2}{|c|}{ Property Misdemeanor } & \multicolumn{2}{|c|}{$\begin{array}{l}\text { Total } \\
\text { Single-Charge } \\
\text { Misdemeanors }\end{array}$} \\
\hline & Convicted & $\begin{array}{l}\text { Number } \\
\text { of Cases }\end{array}$ & Convicted & $\begin{array}{l}\text { Number } \\
\text { of Cases }\end{array}$ \\
\hline No prior arrest record & $23 \%$ & (86) & $52 \%$ & (912) \\
\hline Prior arrests & $41 \%$ & (49) & $58 \%$ & $(285)$ \\
\hline
\end{tabular}

Figures on the disposition of property misdemeanors and disorderly conduct cases by the age of the defendant are somewhat surprising. They show that conviction rates were lower for older defendants for each of these charges, while dismissal rates were higher. (See Table 26.)

TABLE 26

Disposition By Age OF DEFENDANT

\begin{tabular}{lcccc}
\hline \multicolumn{1}{c}{ Age } & $\begin{array}{c}\text { Convicted } \\
\%\end{array}$ & $\begin{array}{c}\text { Discharged } \\
\%\end{array}$ & $\begin{array}{c}\text { Dismissed } \\
\%\end{array}$ & $\begin{array}{c}\text { Number } \\
\text { of cases } \\
(=100 \%)\end{array}$ \\
\hline Disorderly Conduct: & & & & \\
$17-20$ & 68 & 14 & 18 & $(120)$ \\
$21-25$ & 58 & 11 & 31 & $(116)$ \\
$26-35$ & 44 & 14 & 42 & $(117)$ \\
Over 35 & 32 & 10 & 58 & $(69)$ \\
$\quad$ All age groups & 53 & 13 & 35 & $(422)$ \\
Property Misdemeanors: & & & & \\
17-20 & 34 & 11 & 55 & $(47)$ \\
$21-25$ & 31 & 8 & 61 & $(36)$ \\
$26-35$ & 32 & 10 & 58 & $(31)$ \\
Over 35 & 17 & - & 83 & $(12)$ \\
$\quad$ All age groups & 31 & 9 & 60 & $(126)$ \\
\hline
\end{tabular}


Most of the dismissals were apparently on the prosecutor's motion. It appears that the State's Attorney's office was screening on the basis of arrest record in the older age groups. As Table 27 indicates, dismissal rates for those without prior arrest records increase with age for both charge groups and particularly for disorderly conduct.

TABLE 27

Disposttion by Age ANd Prior ARrest Record

\begin{tabular}{|c|c|c|c|c|}
\hline \multirow[b]{2}{*}{ Age } & \multicolumn{2}{|c|}{ Per Cent Convicted } & \multicolumn{2}{|c|}{ Per Cent Dismissed } \\
\hline & $\begin{array}{c}\text { No Prior } \\
\text { Arrest }\end{array}$ & $\begin{array}{c}\text { Prior } \\
\text { Arrests }\end{array}$ & $\begin{array}{l}\text { No Prior } \\
\text { Arrest }\end{array}$ & $\begin{array}{c}\text { Prior } \\
\text { Arrests }\end{array}$ \\
\hline \multicolumn{5}{|c|}{ Disorderly Conduct: } \\
\hline $17-20$ & 67 & 71 & 18 & 17 \\
\hline $21-25$ & 55 & 65 & 33 & 26 \\
\hline $26-35$ & 39 & 52 & 51 & 28 \\
\hline Over 35 & 19 & 71 & 75 & 6 \\
\hline \multicolumn{5}{|c|}{ Property Misdemeanors: } \\
\hline $17-20$ & 24 & 27 & 61 & 43 \\
\hline $21-25$ & 38 & 25 & 50 & 70 \\
\hline $26-35$ & 21 & 71 & 71 & 14 \\
\hline Over 35 & - & 25 & 100 & 75 \\
\hline
\end{tabular}

There may have been an element of retribution involved in the State's Attorney's decision to push for conviction of young defendants because of the prominent role of youth in the early riot period. But according to Assistant State's Attorney William J. Martin these figures probably reflect a subconscious feeling among prosecutors that an older black defendant without a prior criminal record arrested during a riot is an inappropriate case for full prosecution. ${ }^{256}$

256 Interview with William J. Martin, April 26, 1969. We also cross-tabulated disposition at trial for those defendants whose cases were not dismissed by age. Conviction rates at trial were as follows:

\begin{tabular}{lccccc} 
& \multicolumn{2}{c}{ Disorderly Conduct } & & \multicolumn{2}{c}{ Property } \\
\cline { 2 - 3 } \cline { 5 - 6 } $\begin{array}{l}\text { Age in } \\
\text { Years }\end{array}$ & $\begin{array}{l}\text { Number } \\
\text { of Cases }\end{array}$ & $\begin{array}{c}\text { Per Cent } \\
\text { Convicted }\end{array}$ & & $\begin{array}{c}\text { Number } \\
\text { of Cases }\end{array}$ & $\begin{array}{c}\text { Per Cent } \\
\text { Convicted }\end{array}$ \\
\hline $17-20$ & 73 & 77 & & 12 & 58 \\
$21-25$ & 60 & 78 & & 10 & 70 \\
$26-35$ & 55 & 71 & 6 & 50 \\
Over 35 & 21 & 67 & & 1 & 100 \\
Total & 209 & 75 & 29 & 62 \\
\hline
\end{tabular}

These data suggest that trial disposition was not influenced by age to the same extent as dismissals.

The age pattern for dismissals holds for defendants arrested at each stage of the riot, although it is least significant for those arrested during the peak of riot. Data on disorderly conduct dismissals, by age and time of arrest, reveal that younger defendants were 
Table 28 shows conviction rates for curfew, disorderly conduct, and property misdemeanor cases by employment status. No such clear pattern emerges as for prior record or age.

TABLE 28

Conviction Rate by Employment Status

\begin{tabular}{|c|c|c|c|c|c|c|}
\hline \multirow[b]{2}{*}{$\begin{array}{l}\text { Employment } \\
\text { Status }\end{array}$} & \multicolumn{2}{|c|}{ Curfew } & \multicolumn{2}{|c|}{ Disorderly Conduct } & \multicolumn{2}{|c|}{ Property Misdemeanors } \\
\hline & $\begin{array}{l}\text { Per Cent } \\
\text { Convicted }\end{array}$ & $\begin{array}{c}\text { Number } \\
\text { of } \\
\text { Cases }\end{array}$ & $\begin{array}{l}\text { Per Cent } \\
\text { Convicted }\end{array}$ & $\begin{array}{c}\text { Number } \\
\text { of } \\
\text { Cases }\end{array}$ & $\begin{array}{l}\text { Per Cent } \\
\text { Convicted }\end{array}$ & $\begin{array}{c}\text { Number } \\
\text { of } \\
\text { Cases }\end{array}$ \\
\hline Employed & 63 & $(267)$ & 56 & $(245)$ & 35 & (83) \\
\hline Unemployed & 63 & $(169)$ & 46 & (114) & 32 & (25) \\
\hline Student & 55 & (99) & 56 & $(32)$ & 一 & (7) \\
\hline Other & 67 & (3) & 40 & (10) & 14 & (7) \\
\hline
\end{tabular}

3. Disposition: Systemic Factors. Systemic factors influence disposition in different ways, and no single factor can be expected to correlate consistently with disposition. The factors which we have analyzed statistically are those which we initially hypothesized would indicate differential disposition rates-either because they entered directly into judicial decision-making or because they are related to factors which were influential. We found that there are variations in conviction rates for each of the three charge categories dependent upon date and time of arrest, date of dispositive court appearance,

less likely to have their cases dismissed than older arrestees at whatever riot period they were arrested:

\begin{tabular}{|c|c|c|c|c|}
\hline \multirow[b]{3}{*}{$\begin{array}{c}\text { Time of } \\
\text { Arrest }\end{array}$} & \multicolumn{4}{|c|}{ Age (in years) } \\
\hline & \multicolumn{2}{|c|}{$17-20$} & \multicolumn{2}{|c|}{$21-25$} \\
\hline & $\begin{array}{l}\text { Number } \\
\text { of Cases }\end{array}$ & $\begin{array}{l}\text { Per Cent } \\
\text { Dismissed }\end{array}$ & $\begin{array}{l}\text { Number } \\
\text { of Cases }\end{array}$ & $\begin{array}{l}\text { Per Cent } \\
\text { Dismissed }\end{array}$ \\
\hline \multirow[t]{3}{*}{$\begin{array}{l}6 \mathrm{pm} \text { Thursday-6 pm Friday } \\
6 \mathrm{pm} \text { Fri-Midnight Sat. } \\
\text { Sunday } \\
\text { After Sunday }\end{array}$} & $\begin{array}{l}13 \\
65 \\
14 \\
30\end{array}$ & $\begin{array}{l}23 \\
17 \\
14 \\
17\end{array}$ & $\begin{array}{r}9 \\
56 \\
23 \\
25\end{array}$ & $\begin{array}{l}44 \\
21 \\
34 \\
40\end{array}$ \\
\hline & \multicolumn{4}{|c|}{ Age (in years) } \\
\hline & \multicolumn{2}{|c|}{$26-35$} & \multicolumn{2}{|c|}{ Over 35} \\
\hline $\begin{array}{c}\text { Time of } \\
\text { Arrest }\end{array}$ & $\begin{array}{l}\text { Number } \\
\text { of Cases }\end{array}$ & $\begin{array}{l}\text { Per Cent } \\
\text { Dismissed }\end{array}$ & $\begin{array}{l}\text { Number } \\
\text { of Cases }\end{array}$ & $\begin{array}{l}\text { Per Cent } \\
\text { Dismissed }\end{array}$ \\
\hline $\begin{array}{l}6 \mathrm{pm} \text { Thursday-6 pm Friday } \\
6 \mathrm{pm} \text { Fri.-Midnight Sat. } \\
\text { Sunday } \\
\text { After Sunday }\end{array}$ & $\begin{array}{r}8 \\
66 \\
21 \\
18\end{array}$ & $\begin{array}{l}62 \\
30 \\
38 \\
72\end{array}$ & $\begin{array}{l}11 \\
26 \\
11 \\
18\end{array}$ & $\begin{array}{l}91 \\
30 \\
72 \\
72\end{array}$ \\
\hline
\end{tabular}

The small number of property misdemeanor cases does not allow us to examine dismissal patterns by age and time of arrest for defendants arrested on charges in that category. 
length of pretrial custody, and bond history. But these factors did not all influence disposition in the same manner.

Table 29 shows conviction and dismissal rates by time of arrest for curfew, disorderly conduct, and property misdemeanor defendants. The relationship between time of arrest and disposition is different in each charge category. Curferw defendants arrested late in the riot (Sunday or later) were more likely to be convicted than those arrested earlier; disorderly conduct defendants arrested during peak riot hours ( 6 p.m. Friday-Midnight Saturday) were most likely to be convicted; and property misdemeanor defendants arrested during the early riot period ( 6 p.m. Thursday- 6 p.m. Friday) were more likely to be convicted.

TABLE 29

Disposition BY TIME OF ARREST

\begin{tabular}{lcccr}
\hline \multicolumn{1}{c}{ Time of Arrest } & $\begin{array}{c}\text { Per Cent } \\
\text { Convicted }\end{array}$ & $\begin{array}{c}\text { Per Cent } \\
\text { Discharged }\end{array}$ & $\begin{array}{c}\text { Per Cent } \\
\text { Dismissed }\end{array}$ & $\begin{array}{r}\text { Number } \\
\text { of Cases } \\
(=100 \%)\end{array}$ \\
\hline Curfew: & & & & \\
6 pm Thursday-6 pm Friday & - & - & - & $(0)$ \\
6 pm Friday-Midnight Sat. & 48 & 36 & 76 & $(69)$ \\
Sunday & 68 & 24 & 8 & $(148)$ \\
After Sunday & 61 & 20 & 19 & $(329)$ \\
Disorderly Conduct: & & & & \\
6 pm Thursday-6 pm Friday & 39 & 7 & 54 & $(41)$ \\
6 pm Friday-Midnight Sat. & 61 & 15 & 24 & $(209)$ \\
Sunday & 55 & 7 & 38 & $(69)$ \\
After Sunday & 43 & 11 & 46 & $(90)$ \\
Property Misdemeanors: & & & & \\
6 pm Thursday-6 pm Friday & 50 & 4 & 46 & $(24)$ \\
6 pm Friday-Midnight Sat. & 29 & 11 & 59 & $(76)$ \\
Sunday & 29 & 14 & 57 & $(7)$ \\
After Sunday & 14 & - & 86 & $(14)$ \\
\hline
\end{tabular}

There is then no over-all consistent relationship between time of arrest and disposition as we noted earlier existed between bond amount and time of arrest. It seems probable that the courts responded less to the pattern of events in the streets when they eventually disposed of riot cases than they had during the riot and its immediate aftermath when they set bond.

One possible test of the relationship between changing judicial attitudes toward riot arrestees over time and the disposition of riot cases is conviction rates by date of disposition. Table 30 shows, how- 
ever, that conviction rates for curfew and disorderly conduct defendants increased sharply for cases disposed of after April 28-more than two weeks after the end of the riot. For property misdemeanors, on the other hand, the pattern is reversed. The later the disposition of a property charge, the more likely was a dismissal or acquittal on the merits.

TABLE 30

Conviction Rates by Date of Court Disposition

\begin{tabular}{llccr}
\hline \multicolumn{1}{c}{ Date } & \multicolumn{3}{c}{ Per Cent Convicted } & Number \\
\cline { 2 - 5 } & Total & Guilty Plea & Trial & \\
\hline Curfew: & & & & $(92)$ \\
April 5-27 & 26 & 10 & 17 & $(346)$ \\
April 28-June 1 & 64 & 32 & 32 & $(135)$ \\
After June 1 & 76 & 25 & 51 & \\
Disorderly Conduct: & & & & $(235)$ \\
April 5-27 & 40 & 17 & 23 & $(107)$ \\
April 28-June 1 & 59 & 7 & 51 & $(102)$ \\
After June 1 & 69 & 22 & 47 & \\
Property Misdemeanors: & & & & $(18)$ \\
April 5-27 & 83 & 50 & 33 & $(73)$ \\
April 28-June 1 & 28 & 19 & 9 & \\
\hline
\end{tabular}

In part, these patterns reflect different dismissal patterns for the different charge categories. As noted earlier, some magistrates dismissed curfew charges at bond hearings. This probably accounts for a significant proportion of the dismissals before April 28. Forty-nine per cent of the curfew defendants whose cases were heard before April 27 were dismissed, but only about $10 \%$ of those whose cases were heard after that date were dismissed. Magistrates apparently also dismissed disorderly conduct cases at early stages. Forty-four per cent of disorderly conduct cases disposed of before April 27 were dismissed, while only $28 \%$ of disorderly conduct cases heard after that date were dismissed. Dismissals of property misdemeanor cases, on the other hand, as we have seen, were predominantly on the motion of the prosecutor, which may explain why they were granted later. Seventeen per cent of the property misdemeanor cases disposed of before April 27 were dismissed, while $70 \%$ of those disposed of later were dismissed.

But dismissal rates do not totally explain the disposition data. Table 31 demonstrates that the conviction rate among cases disposed of at trial increased for curfew and disorderly conduct defendants 
and decreased for property misdemeanor defendants the later the case was heard. And the evidence of guilty pleas also fails to explain the relationship between date of dispositive court appearance and conviction rates. (See Table 30.)

While guilty pleas represent a greater proportion of curfew defendants disposed of the longer after the riot the disposition occurred, the data indicate that the conviction rate at trial was also higher for those cases disposed of later. The proportion of guilty pleas for disorderly conduct actually dropped for cases heard in May, but nevertheless the conviction rate increased, as more than four-fifths of those whose cases were tried were convicted. Property misdemeanor guilty pleas declined after April, as did the conviction rate at trial.

TABLE 31

Conviction Rate at Trial by Date of Court Disposition

\begin{tabular}{|c|c|c|c|c|c|c|}
\hline \multirow[b]{2}{*}{ Date } & \multicolumn{2}{|c|}{ Curfew } & \multicolumn{2}{|c|}{ Disorderly Conduct } & \multicolumn{2}{|c|}{ Property Misdemeanor } \\
\hline & $\begin{array}{l}\text { Per Cent } \\
\text { Convicted }\end{array}$ & $\begin{array}{c}\text { Number } \\
\text { of Cases } \\
\text { Tried }\end{array}$ & $\begin{array}{l}\text { Per Cent } \\
\text { Convicted }\end{array}$ & $\begin{array}{c}\text { Number } \\
\text { of Cases } \\
\text { Tried }\end{array}$ & $\begin{array}{l}\text { Per Cent } \\
\text { Convicted }\end{array}$ & $\begin{array}{c}\text { Number } \\
\text { of Cases } \\
\text { Tried }\end{array}$ \\
\hline April 5-27 & 51 & $(47)$ & 73 & (131) & 100 & $(15)$ \\
\hline April 28-June 1 & 71 & (31) & 83 & $(76)$ & 80 & (15) \\
\hline After June 1 & 87 & (118) & 92 & $(76)$ & 60 & (20) \\
\hline
\end{tabular}

The most likely explanation for the relationship between date of dispositive court appearance and conviction is that different magistrates sat at different times. As we shall see, ${ }^{257}$ each magistrate had a distinctive method of disposing of riot cases. But one of the important factors determining the date of a defendant's court appearance is whether or not he secured release on bail or recognizance.

Generally in Cook County the cases of criminal defendants not out on bail are advanced on the docket. During the riot, the presiding judge of the Municipal Division announced that this practice would be carried out for riot arrestees. ${ }^{258}$ Our data indicate that earlier hearings were generally held for misdemeanants who did not make bail. (See Table 32.)

Disposition by bond history is shown in Table 33. For curfew and disorderly conduct it shows a higher conviction rate for those making cash bond than for those not making bond and a still higher conviction rate for those released on their own recognizance. For property misdemeanor cases, on the other hand, conviction rates were lower 
TABLE 32

Date OF Court Disposition bY BOND History

\begin{tabular}{|c|c|c|c|}
\hline Date & $\begin{array}{c}\text { Bond Not Made } \\
\%\end{array}$ & $\begin{array}{c}\text { Cash Bond Made } \\
\%\end{array}$ & $\begin{array}{c}\mathbf{R} \mathbf{~ R} \\
\%\end{array}$ \\
\hline \multicolumn{4}{|l|}{ Curfew: } \\
\hline April 5-27 & 50 & 49 & 3 \\
\hline April 28-June 1 & 38 & 24 & 72 \\
\hline After June I & 13 & 28 & 24 \\
\hline Number of cases & $\begin{array}{r}100 \\
(8)\end{array}$ & $\begin{array}{l}100 \\
(76)\end{array}$ & $\begin{array}{c}100 \\
(442)\end{array}$ \\
\hline \multicolumn{4}{|l|}{ Disorderly Conduct: } \\
\hline April 5-27 & 74 & 56 & 18 \\
\hline April 28-June 1 & 10 & 25 & 35 \\
\hline After June I & 16 & 19 & 47 \\
\hline Number of cases & $\begin{array}{l}100 \\
(31)\end{array}$ & $\begin{array}{l}100 \\
(252)\end{array}$ & $\begin{array}{l}100 \\
(102)\end{array}$ \\
\hline \multicolumn{4}{|c|}{ Property Misdemeanors: } \\
\hline April 5-27 & 41 & 5 & 一 \\
\hline April 28-June 1 & 37 & 27 & 50 \\
\hline \multirow[t]{2}{*}{ After June 1} & 22 & 68 & 50 \\
\hline & 100 & 100 & 100 \\
\hline Number of cases & (27) & (93) & (2) \\
\hline
\end{tabular}

for those released on bond. ${ }^{259}$ Moreover, as Table 33 indicates, the changes in conviction rate over time are primarily the result of charging dismissal, not discharge, rates. Curfew and disorderly conduct defendants released on bail or ROR were more likely than those not released to be tried later and convicted, while property misdemeanor defendants released on bail or ROR were more likely to have their cases dismissed or discharged at a later court appearance than those who were not released. Bond history, then, appears to have indirectly affected conviction rates by influencing the date on which a case was disposed of. But it is also important to consider the direct impact of bond history on the likelihood of conviction. ${ }^{200}$ It would

259 It should be pointed out, however, that less than $2 \%$ of the curfew violators and $7 \%$ of the disorderly conduct arrestees, but $22 \%$ of the property misdemeanants, were unable to make bond. In addition, bond forfeitures may have had some effect on the higher conviction rates for the curfew and disorderly conduct defendants released on bond. In Illinois forfeiture of bond is a felony, but the usual procedure is to vacate the forfeiture and quash the warrant for arrest if a defendant appears in court within 30 days. This practice was followed for most riot misdemeanor cases. Eighty-one per cent and $88 \%$, respectively, of the curfew and disorderly conduct defendants who missed court appearances were convicted. In comparison, only one of the four property misdemeanor defendants who forfeited bond was convicted.

260 See Rankin, The Effect of Pretrial Detention, 39 N.Y.U.L. REv. 641 (1964). 
seem logical that those unable to make bond-and, therefore, detained until the disposition of their cases-would be more likely to plead guilty in exchange for sentence or fine credit for time already served. ${ }^{261}$

TABLE 33

DisPosITION BX BOND HISTORY

\begin{tabular}{lcccc}
\hline \multicolumn{1}{c}{ Bond History } & $\begin{array}{c}\text { Convicted } \\
\%\end{array}$ & $\begin{array}{c}\text { Discharged } \\
\%\end{array}$ & $\begin{array}{c}\text { Dismissed } \\
\%\end{array}$ & $\begin{array}{r}\text { Number } \\
\text { of Cases } \\
(=100 \%)\end{array}$ \\
\hline Curfew: & & & & \\
Bond not made & 50 & 12 & 38 & $(8)$ \\
Cash bond made & 55 & 32 & 13 & $(77)$ \\
ROR & 67 & 23 & 10 & $(443)$ \\
Disorderly Conduct: & & & & \\
$\begin{array}{l}\text { Bond not made } \\
\text { Cash bond made }\end{array}$ & 45 & 10 & 45 & $(31)$ \\
ROR & 57 & 17 & 26 & $(252)$ \\
Property Misdemeanors: & 62 & 10 & 28 & $(102)$ \\
Bond not made & 62 & & & \\
Cash bond made & 22 & 5 & 33 & $(27)$ \\
ROR & - & - & 67 & $(94)$ \\
\hline
\end{tabular}

But Table 34 shows that there is no consistent relationship between bond history and conviction rates for those charged with curfew violations or disorderly conduct when we control for date of disposition. Among property misdemeanor defendants, on the other hand,

TABLE 34

Conviction Rates by Bond History and Date of Court Dispostrion

\begin{tabular}{|c|c|c|c|c|c|c|c|c|c|}
\hline \multirow[b]{3}{*}{$\begin{array}{l}\text { Bond } \\
\text { History }\end{array}$} & \multicolumn{9}{|c|}{ Per Cent Convicted } \\
\hline & \multicolumn{3}{|c|}{ Curfew } & \multicolumn{3}{|c|}{ Disorderly Conduct } & \multicolumn{3}{|c|}{ Property Misdemeanors } \\
\hline & $\begin{array}{l}\text { April 5- } \\
\text { April } 27\end{array}$ & $\begin{array}{c}\text { April 28- } \\
\text { June } 1\end{array}$ & $\begin{array}{c}\text { After } \\
\text { June } 1\end{array}$ & $\begin{array}{l}\text { April 5- } \\
\text { April } 27\end{array}$ & $\begin{array}{l}\text { April 28- } \\
\text { June } 1\end{array}$ & $\begin{array}{c}\text { After } \\
\text { June } 1\end{array}$ & $\begin{array}{l}\text { April 5- } \\
\text { April } 27\end{array}$ & $\begin{array}{l}\text { April 28- } \\
\text { June I }\end{array}$ & $\begin{array}{l}\text { After } \\
\text { June } 1\end{array}$ \\
\hline $\begin{array}{l}\text { Bond not } \\
\text { made }\end{array}$ & 50 & 67 & 46 & 54 & 一 & 40 & 91 & 60 & 一 \\
\hline $\begin{array}{l}\text { Cash bond } \\
\text { made }\end{array}$ & d 39 & 73 & 63 & 54 & 68 & 59 & 60 & 24 & 17 \\
\hline ROR & 46 & 63 & 81 & 22 & 55 & 81 & 一 & - & - \\
\hline
\end{tabular}

there is a consistent relationship. Those defendants who did not make bond were far more likely to be convicted than those who made bond whether their cases were heard before or after April 27. 
No significantly greater proportion of curfew and disorderly conduct defendants who were not released on bond pleaded guilty than of those who were released. Indeed, a smaller percentage of the few curfew defendants not released on bond pleaded guilty than of those who were released. The opposite was true with respect to property misdemeanor defendants: a far greater proportion of those who did not make bond pleaded guilty than of those who were released before trial. (See Table 35.)

TABLE 35

Guilty Plea and Trial Conviction Rate

\begin{tabular}{|c|c|c|c|c|}
\hline \multirow[b]{2}{*}{ Bond History } & \multicolumn{3}{|c|}{ Per Cent Convicted } & \multirow{2}{*}{$\begin{array}{l}\text { Number } \\
\text { of Cases }\end{array}$} \\
\hline & Total & Guilty Plea & At Trial & \\
\hline \multicolumn{5}{|l|}{ Gurfew: } \\
\hline Bond not made & 50 & 13 & 38 & (8) \\
\hline Cash bond made & 55 & 18 & 36 & (77) \\
\hline ROR & 67 & 34 & 33 & (443) \\
\hline \multicolumn{5}{|l|}{ Disorderly Conduct: } \\
\hline Bond not made & 45 & 26 & 19 & (31) \\
\hline Cash bond made & 58 & 17 & 41 & (252) \\
\hline ROR & 62 & 21 & 41 & (102) \\
\hline \multicolumn{5}{|c|}{ Property Misdemeanors: } \\
\hline Bond not made & 59 & 44 & 15 & (27) \\
\hline Cash bond made & 22 & 12 & 11 & (94) \\
\hline ROR & 一 & 一 & - & (2) \\
\hline
\end{tabular}

The time which a defendant spent in jail prior to the disposition of his case might be expected to influence conviction rates more directly than bond history. Predisposition custody time could have either of two opposite effects on disposition. On the one hand, longer predisposition custody time would be expected to induce more guilty pleas for minor misdemeanors, in exchange for crediting the detention time against fines or sentences. On the other hand, longer pretrial detention might lead to increased dismissal and discharge rates because magistrates regard the pretrial custody as punishment enough for minor charges.

Among curfew defendants, the latter tendency appears to have predominated: those detained three days or longer less often pleaded guilty, but were more often convicted at trial. Among those charged with disorderly conduct, both effects seems to have operated: those detained three days or longer more often pleaded guilty but, if they did not, were less likely to be convicted the longer they had been detained. Guilty plea rates increased sharply among property mis- 
demeanor defendants detained three days or longer; conviction rates at trial, on the other hand, showed an ambiguous pattern with increasing pretrial detention time. (See Table 36.)

Our data suggest that pretrial detention was often considered sufficient punishment for those charged with curfew violations and disorderly conduct. In part, this may reflect the large number of young persons and ghetto residents without prior criminal records arrested on these charges. Those defendants who had secured release on ROR or bail, however, were more often convicted than those who did not, suggesting a judicial reluctance to allow minor riot offenders off without some from of punishment.

For many property misdemeanor defendants, on the other hand, even lengthy pretrial detention was not considered sufficient punishment. Those detained longer were more likely to be convicted, whether because they were induced to plead guilty or (except for those detained over 30 days) because a magistrate was less willing to consider time served sufficient punishment without a formal finding of guilt. The very low conviction rate at trial for those detained over 30 days suggests that magistrates were considering pretrial custody of this length as sufficient punishment without a conviction.

TABLE 36

Guilty plea and Trial Conviction Rate by Length of Predisposition Custody

\begin{tabular}{lcccr}
\hline & \multicolumn{3}{c}{ Per Cent Convicted } & Number of \\
\cline { 2 - 4 } & Total & Guilty Plea & Trial & \\
\hline Curfew: & & & & \\
$0-2$ & 62 & 28 & 34 & $(569)$ \\
$3-10$ & 50 & 10 & 40 & $(10)$ \\
$11-30$ & 56 & 11 & 44 & $(9)$ \\
Over 30 & 52 & 9 & 43 & $(23)$ \\
Disorderly Conduct: & & & & \\
$0-2$ & 51 & 13 & 38 & $(312)$ \\
$3-10$ & 55 & 23 & 32 & $(74)$ \\
$11-30$ & 52 & 23 & 29 & $(31)$ \\
Over 30 & 41 & 24 & 18 & $(17)$ \\
Property Misdemeanors: & & & & \\
$0-2$ & 19 & 6 & 13 & $(48)$ \\
$3-10$ & 32 & 20 & 12 & $(41)$ \\
$11-30$ & 56 & 25 & 31 & $(16)$ \\
Over 30 & 31 & 23 & 8 & $(26)$ \\
\hline
\end{tabular}

4. Sentencing. Sentences for convicted riot misdemeanants were predominantly fines of relatively small amounts. Tables 37 and 38 give 
a breakdown of sentence type and fine amounts for those convicted of misdemeanors. ${ }^{262}$ Sentence type, if curfew and disorderly conduct cases are excluded, is very similar to that for normal misdemeanors. In 1963, the last year for which comparable data are available, $24 \%$ of the convicted misdemeanants were fined, $21 \%$ were placed on probation, and $55 \%$ were imprisoned. ${ }^{263}$ The comparable distribution for the serious riot misdemeanors is $26 \%, 15 \%$, and $59 \%$. No data are available to compare severity of sentences.

Three-fourths of the multiply-charged misdemeanants and $57 \%$ of the singly-charged misdemeanants who were fined were credited with

TABLE 37

Sentences by Charge

\begin{tabular}{|c|c|c|c|c|c|c|}
\hline . & $\begin{array}{c}\text { Curfew } \\
\%\end{array}$ & $\begin{array}{c}\text { Disorderly } \\
\text { Conduct } \\
\%\end{array}$ & $\begin{array}{c}\text { Resisting } \\
\text { Arrest } \\
\%\end{array}$ & $\begin{array}{c}\text { Misde- } \\
\text { meanors } \\
\text { against } \\
\text { Persons } \\
\%\end{array}$ & $\begin{array}{c}\text { Property } \\
\text { Misde- } \\
\text { meanors } \\
\%\end{array}$ & $\begin{array}{c}\text { Total } \\
\%\end{array}$ \\
\hline Fine & 97 & 97 & 59 & 25 & 5 & 91 \\
\hline Probation & - & 1 & 一 & 50 & 10 & a \\
\hline $\begin{array}{l}\text { Fine and } \\
\text { probation }\end{array}$ & 一 & - & - & - & 20 & 2 \\
\hline $\begin{array}{l}\text { Prison and } \\
\text { probation }\end{array}$ & 一 & a & 18 & 25 & 43 & 3 \\
\hline Prison & $\mathfrak{a}$ & 2 & 23 & - & 23 & 4 \\
\hline & 100 & 100 & 100 & 100 & 100 & 100 \\
\hline $\begin{array}{l}\text { Number } \\
\text { of Cases }\end{array}$ & (353) & (229) & (17) & (4) & $(40)$ & $(646)^{b}$ \\
\hline
\end{tabular}

a Less than $1 / 2$ of 1 per cent.

b Includes three fines imposed in other misdemeanor cases.

having worked off their fines on the basis of the time they had spent in custody prior to trial. ${ }^{264}$ Of those sentenced to jail, $54 \%$ of the multiply-charged and $74 \%$ of the singly-charged were credited with the time they had spent prior to trial..$^{265}$

262 Of the 43 misdemeanants sentenced to time in jail, $35 \%$ were sentenced to 10 days or less and $47 \%$ to $11-30$ days.

263 OAKs \& LeHMAN 39, Table 7.

204 Illinois law requires that detention time prior to sentencing for those defendants not making bail for a bailable offense be credited toward the fine imposed at the rate of $\$ 5$ per day. IrL. REv. STAT. ch. 38, § 110-14 (1967).

265 Sixty-four per cent of the misdemeanants sentenced to jail, or jail and probation, had been convicted of property misdemeanors and $26 \%$ had been convicted for resisting arrest. Seventy per cent of the property misdemeanants were given sentence credit, but only $30 \%$ of those convicted of resisting arrest. 
TABLE 38

AMOUNTS OF FINE

\begin{tabular}{|c|c|c|c|c|c|c|}
\hline Fine Amount & $\begin{array}{c}\text { Curfew } \\
\%\end{array}$ & $\begin{array}{c}\text { Disorderly } \\
\text { Conduct } \\
\%\end{array}$ & $\begin{array}{c}\text { Resisting } \\
\text { Arrest } \\
\%\end{array}$ & $\begin{array}{c}\text { Misde- } \\
\text { meanors } \\
\text { against } \\
\text { Persons } \\
\%\end{array}$ & $\begin{array}{c}\text { Property } \\
\text { Misde- } \\
\text { meanors } \\
\%\end{array}$ & $\begin{array}{c}\text { Total } \\
\%\end{array}$ \\
\hline$\$ 5-\$ 15$ & 52 & 61 & 45 & 100 & 40 & 55 \\
\hline$\$ 16-\$ 50$ & 47 & 31 & 36 & - & 一 & 40 \\
\hline$\$ 51-\$ 150$ & 1 & 5 & 18 & - & 60 & 4 \\
\hline Over $\$ 150$ & * & 3 & 一 & - & - & 1 \\
\hline $\begin{array}{l}\text { Number of } \\
\text { Cases }\end{array}$ & $\begin{array}{l}\overline{100} \\
(345)\end{array}$ & $\begin{array}{l}\overline{100} \\
(221)\end{array}$ & $\begin{array}{l}\overline{100} \\
\text { (11) }\end{array}$ & $\begin{array}{l}100 \\
\text { (1) }\end{array}$ & $\begin{array}{l}\overline{100} \\
(5)\end{array}$ & $\begin{array}{l}\overline{100} \\
(583)\end{array}$ \\
\hline
\end{tabular}

- Less than $1 / 2$ of 1 per cent.

These figures suggest that for many misdemeanants post-trial sentencing was largely a formality. In Table 39 we compare fine amounts for those convicted of curfew and disorderly conduct and sentence lengths for those convicted of property misdemeanors with length of pretrial detention. The fine amounts for half those fined for curfew violations and three-fifths of those fined for disorderly conduct were the equivalent of detention for a period shorter than or equal to their pretrial detention. The length of prison sentences imposed on threefifths of the property misdemeanants sentenced to prison or prison and probation was shorter than or equal to their pretrial detention.

TABLE 99

Comparison of Length of Pretrial Detention and Sentence*

\begin{tabular}{lccc}
\hline \multicolumn{1}{c}{ Sentence } & $\begin{array}{c}\text { Curfew } \\
\%\end{array}$ & $\begin{array}{c}\text { Disorderly } \\
\text { Conduct } \\
\%\end{array}$ & $\begin{array}{c}\text { Property } \\
\text { Misdemeanors } \\
\%\end{array}$ \\
\hline $\begin{array}{l}\text { Less than or equal } \\
\text { to pretrial detention }\end{array}$ & 49 & 61 & 59 \\
$\begin{array}{c}\text { Greater than } \\
\text { pretrial detention }\end{array}$ & 52 & $\frac{38}{100}$ & $\underline{41}$ \\
Number of cases & 100 & $(220)$ & 100 \\
\hline
\end{tabular}

* Fines are translated into days at the Illinois rate of $\$ 5=1$ day.

Data on the severity of sentences by plea show that those pleading guilty to curfew violations and disorderly conduct were more likely to be fined greater amounts; there is no comparable relationship between the length of sentence imposed on those few persons con- 
victed or property misdemeanors and plea, but the number of cases is small. (See Table 40.)

TABLE 40

AMOUNTS OF Fine by Type OF PleA

\begin{tabular}{|c|c|c|c|c|}
\hline \multirow[b]{2}{*}{$\begin{array}{l}\text { Fine Amount } \\
\text { (in \$) }\end{array}$} & \multicolumn{2}{|c|}{ Curfew } & \multicolumn{2}{|c|}{ Disorderly Conduct } \\
\hline & $\begin{array}{c}\text { Guilty } \\
\text { Plea } \\
\%\end{array}$ & $\begin{array}{c}\text { Convicted After } \\
\text { Not Guilty } \\
\text { Plea } \\
\%\end{array}$ & $\begin{array}{c}\text { Guilty } \\
\text { PIea } \\
\%\end{array}$ & $\begin{array}{c}\text { Convicted After } \\
\text { Not Guilty } \\
\text { Plea } \\
\%\end{array}$ \\
\hline 0.5 & 1 & 3 & - & 3 \\
\hline $6-10$ & 19 & 70 & 38 & 64 \\
\hline $11-15$ & - & 1 & 3 & 1 \\
\hline 16.50 & 79 & 24 & 56 & 22 \\
\hline $51-150$ & 1 & 1 & 3 & 6 \\
\hline Over 150 & 1 & 一 & 一 & 4 \\
\hline & 100 & 100 & 100 & 100 \\
\hline $\begin{array}{l}\text { Number } \\
\text { of Cases }\end{array}$ & (150) & (175) & (64) & (I48) \\
\hline
\end{tabular}

These figures do not necessarily show that those pleading guilty were not in fact treated as leniently as those convicted after a not-guilty plea. As we have seen, sentence severity often reflected pretrial detention time. For example, $35 \%$ of those who pleaded guilty to disorderly conduct spent four or more days in custody before trial while only $20 \%$ of those convicted at trial were detained that long.

Sentencing is within the discretion of the individual magistrate. We would expect that the behavior patterns of the magistrates, more than any other factor, will explain sentence data. We turn to an analysis of disposition and sentencing patterns for different magistrates.

5. Magistrates: Disposition and Sentencing Practices. Four magistrates disposed of more than four-fifths of the curfew violations, disorderly conduct, and property misdemeanor cases stemming from the riot. Table 41 indicates that Judge Wendt heard at least one-quarter of the cases in each of these categories, and Magistrate Lee heard more than one-eighth of each category. ${ }^{268}$

266 We checked the incidence of prior arrest records among the defendants heard by each magistrate, to see whether there were personal factors which accounted for the different disposition patterns of each magistrate. The results by charge are as follows:

Per Cent With No Prior Record

\begin{tabular}{lccc}
\hline Magistrate & Curfew & $\begin{array}{c}\text { Disorderly } \\
\text { Conduct }\end{array}$ & $\begin{array}{c}\text { Property } \\
\text { Misdemeanors }\end{array}$ \\
\hline Wendt & 86 & 62 & 48 \\
Lee & 88 & 60 & 69 \\
Limperis & 84 & 60 & 68 \\
Gill & 85 & 60 & 67 \\
\hline
\end{tabular}

There is remarkable similarity among the cases which came before the four magistrates. 
Judge Wendt normally serves on the Narcotics Court, where he is known for his ability to dispose of a large daily caseload efficiently and fairly. He supervised the setting of the docket and the assignment of magistrates to handle riot cases, as well as hearing a large number himself. As a judge, Wendt is in a more secure position than magistrates, whose terms expire each year. ${ }^{267}$

TABLE 41

Distribution of Cases among maglstrates

\begin{tabular}{lccc}
\hline & $\begin{array}{c}\text { Curfew } \\
\text { Magistrate }\end{array}$ & $\begin{array}{c}\text { Disorderly } \\
\text { Conduct } \\
\%\end{array}$ & $\begin{array}{c}\text { Property } \\
\text { Misdemeanor }\end{array}$ \\
\hline Wendt & 25 & 35 & $\%$ \\
Lee & 24 & 15 & 37 \\
Limperis & 20 & 12 & 27 \\
Gill & 13 & 10 & 23 \\
All Others & 18 & 28 & 5 \\
& 100 & 100 & 15 \\
Number of Cases & $(558)$ & $(447)$ & 100 \\
\hline
\end{tabular}

Tables 42 and 43 show that Judge Wendt handled each category of riot cases in a different manner than the three magistrates. $\mathrm{He}$ acquitted only $1 \%$ of disorderly conduct defendants, and none of those charged with curfew or a property misdemeanor. Ninety-three per cent of the property misdemeanor cases which came before him were dismissed, a far higher percentage than for Magistrates Lee, Limperis or Gill.

Wendt's sentences, however, were much more lenient than those of the magistrates. Table 44 shows that he fined $96 \%$ of those he convicted of curfew violations, and $92 \%$ of those he convicted of disorderly conduct, $\$ 10$ or less. And, as Table 45 shows, $98 \%$ of those he fined were given credit for time served equivalent to the amount of the fine.

Wendt apparently considered curfew and disorderly conduct charges as similar enough to be treated in the same way. His disposition of these cases-conviction and a fine, with time considered served-suggests that he was legitimating the arrests made during the riot, but saw no need to impose further punishment. If that is an accurate statement of his attitude, it was perceived by many of the arrestees we interviewed, who recognized their initial arrest and predisposition detention as their primary punishment.

Data on the age of defendants whose cases were disposed of by each magistrate show greater discrepancies. Limperis heard a somewhat greater proportion of those over 25 than the other magistrates,

287 See Section I supra. 
TABLE 42

Disposmion By Magistrate

\begin{tabular}{lccccc}
\hline & \multicolumn{2}{c}{ Convicted } & & & \\
\cline { 2 - 5 } Muilty & Plea & & & \\
Magistrate & $\%$ & $\begin{array}{c}\text { Trial } \\
\%\end{array}$ & $\begin{array}{c}\text { Discharged } \\
\%\end{array}$ & $\begin{array}{c}\text { Dismissed } \\
\%\end{array}$ & $\begin{array}{c}\text { Number } \\
(=100 \%)\end{array}$ \\
\hline Curfew: & & & & & \\
Wendt & 9 & 81 & - & 10 & $(140)$ \\
Lee & 22 & 7 & 64 & 7 & $(137)$ \\
Limperis & 37 & 39 & 4 & 26 & $(111)$ \\
Gill & 44 & 19 & 31 & 6 & $(73)$ \\
Disorderly Conduct: & & & & & \\
Wendt & 12 & 75 & 7 & 12 & $(140)$ \\
Lee & 21 & 20 & 35 & 24 & $(67)$ \\
Limperis & 25 & 12 & 12 & 52 & $(53)$ \\
Gill & 5 & 47 & 19 & 30 & $(55)$ \\
Property & Misdemeanors: & & & & \\
Wendt & - & 7 & - & 93 & $(41)$ \\
Lee & 31 & 8 & 17 & 44 & $(36)$ \\
Limperis & 13 & 20 & 3 & 64 & $(31)$ \\
Gill & 67 & & - & 33 & $(6)$ \\
\hline
\end{tabular}

TABLE 48

Conviction Rates at Trial by Magistrates

\begin{tabular}{lccc}
\hline & Curfew & Disorderly & \multicolumn{2}{c}{ Property } \\
Magistrate & $\%$ & Conduct & Misdemeanors \\
\hline Wendt & 100 & $\%$ & $\%$ \\
Lee & 10 & 99 & 100 \\
Limperis & 93 & 36 & 33 \\
Gill & 39 & 50 & 86 \\
\hline
\end{tabular}

TABLE 44

Amount of Fine by Magistrate

\begin{tabular}{lcccc}
\hline & \multicolumn{3}{c}{ Per Cent } & Number \\
Magistrate & $\$ 5-\$ 10$ & $\$ 15-\$ 25$ & Over $\$ 25$ & $(=100 \%)$ \\
\hline Curfew: & & & & $(125)$ \\
Wendt & 96 & 4 & -34 & $(41)$ \\
Lee & 7 & 59 & 8 & $(78)$ \\
Limperis & 50 & 41 & 4 & $(46)$ \\
Gill & 2 & 93 & & \\
Disorderly Conduct: & & & 6 & $(120)$ \\
Wendt & 92 & 2 & 67 & $(24)$ \\
Lee & 4 & 29 & 54 & $(18)$ \\
Limperis & 22 & 23 & 10 & $(21)$ \\
Gill & 19 & 71 & & \\
\hline
\end{tabular}


TABLE 45

Fine Credit for Pretrual Detention Time by Magistrate

\begin{tabular}{|c|c|c|c|c|}
\hline \multirow[b]{2}{*}{ Magistrate } & \multicolumn{3}{|c|}{$\begin{array}{l}\text { Percentage of Those Fined Given Credit } \\
\text { for Pretrial Detention }\end{array}$} & \multirow[b]{2}{*}{$\begin{array}{l}\text { Number } \\
\text { Fined }\end{array}$} \\
\hline & Total & $\begin{array}{l}\text { Full Amount } \\
\text { of Fine } \\
\text { Credited }\end{array}$ & $\begin{array}{l}\text { Less Than } \\
\text { Full Amount } \\
\text { Credited }\end{array}$ & \\
\hline \multicolumn{5}{|l|}{ Curfew: } \\
\hline Wendt & 98 & 96 & 2 & (125) \\
\hline Lee & 34 & 12 & 22 & $(41)$ \\
\hline Limperis & 74 & 41 & 33 & (78) \\
\hline Gill & 24 & 7 & 17 & (46) \\
\hline \multicolumn{5}{|c|}{ Disorderly Conduct: } \\
\hline Wendt & 99 & 97 & 2 & $(120)$ \\
\hline Lee & 58 & 29 & 29 & (24) \\
\hline Limperis & 61 & 39 & 22 & (18) \\
\hline Gill & 81 & 52 & 29 & (21) \\
\hline
\end{tabular}

Magistrate Lee, in contrast with Judge Wendt, found relatively few defendants guilty at trial. But $96 \%$ of the disorderly conduct defendants he convicted he fined $\$ 15$ or more. Only $34 \%$ of the curfew sentences included credit for time served, and for only $12 \%$ this credit was equal to the full amount of the fine.

Magistrate Lee normally sits in Branch 36, where most misdemeanor cases are eventually tried, and has presided at the disposition of many past mass arrest cases in Chicago. He has been criticized by the Negro bar for the handling of these cases. In dealing with riot misdemeanor cases, he seems to have decided each case on an individual basis, unlike Judge Wendt. In an interview, he indicated that he repeatedly refused to cooperate with the State's Attorney in promising defendants who pleaded guilty that they would be sentenced only to time already considered served. ${ }^{208}$ The relatively harsh fines Magistrate Lee levied in some cases required several indigent defendants to spend additional time in jail to work off their fines.

Magistrate Limperis served in the Corporation Counsel's office and as a private attorney before becoming a magistrate. $\mathrm{He}$ also has been active in the Democratic party. Until recently, when he was transferred to a civil court, Limperis served in Branch 46 and, when necessary, Branch 47. Like Magistrate Lee, he has been criticized by black lawyers and civil rights groups for his handling of mass arrest cases before the riot.

Limperis had a much higher conviction rate than Magistrate Lee 
for those curfew, disorderly conduct, and property misdemeanor cases he heard on the merits, but he also dismissed more cases. The fines he imposed were generally lower than Lee's, but he did fine half of the convicted curfew violators $\$ 15$ or more and over half of the convicted disorderly conduct defendants over \$25. More than twofifths of the curfew fines and nearly two-fifths of the disorderly conduct fines, however, were fully disposed of by crediting predisposition detention. Only one-fourth of the curfew violators and two-fifths of the disorderly conduct offenders had to pay the full fine amount.

Gill, an ex-State's Attorney, dismissed very few curfew cases. His conviction rate at trial on the merits was between Lee's and Limperis's. He dismissed a higher percentage of disorderly conduct cases than Judge Wendt and Magistrate Lee, and convicted a large proportion of those going to trial on the merits. It would appear that, unlike Judge Wendt, he did not follow a uniform conviction policy. When he did convict, however, he levied fines of $\$ 15-\$ 25$ fairly uniformly. He credited time served against the fine for only one-fourth of the curfew defendants he convicted. He handled disorderly offenders somewhat differently, crediting four-fifths with time served.

Each of the four men seems, then, to have had a distinctive method of handling riot misdemeanor cases. We hypothesized earlier that differences in conviction percentage rates by date of dispositive court appearance might be the result of the policies of different magistrates who sat at different periods. In Table 46, we indicate the distribution of cases by date for the four magistrates whose performance we have analyzed. The figures appear to support our hypothesis: Wendt, whose conviction rate was very high for curfew and disorderly conduct, heard a greater proportion of the later cases, which undoubtedly accounts in part for the high conviction rate among curfew and disorderly conduct defendants tried during later periods. It is also likely that the effect of a defendant's ability to make bond, or length of predisposition custody, on his likelihood of conviction depended upon the particular magistrate before whom his case was heard. The policies of each magistrate or judge account for much of the variation in the disposition of the riot misdemeanor cases.

Our analysis of misdemeanor cases has demonstrated that age and prior arrest record, taken in conjunction, were influential factors in the disposition of riot cases. Cases against disorderly conduct and property misdemeanor defendants were more likely to be dismissed the older a defendant was-provided that he had no prior arrest record. In not pressing for conviction in these cases, the State's Attor- 
TABLE 46

Distrubution of Cases among Magistrates by Date of Court Disposition

\begin{tabular}{|c|c|c|c|c|c|c|}
\hline \multirow[b]{2}{*}{ Magistrate } & \multicolumn{3}{|c|}{ Curfew } & \multicolumn{3}{|c|}{ Disorderly Conduct } \\
\hline & $\begin{array}{c}\text { April } \\
\%\end{array}$ & $\begin{array}{c}\text { April 28- } \\
\text { June } 1 \\
\%\end{array}$ & $\begin{array}{c}\text { After } \\
\text { June } 1 \\
\%\end{array}$ & $\begin{array}{c}\text { April } 5-27 \\
\%\end{array}$ & $\begin{array}{c}\text { April 28- } \\
\text { June } 1 \\
\%\end{array}$ & $\begin{array}{c}\text { After } \\
\text { June } 1 \\
\%\end{array}$ \\
\hline Wendt & 14 & 20 & 41 & 10 & 49 & 67 \\
\hline Lee & 20 & 32 & 6 & 18 & 18 & 7 \\
\hline Gill & 5 & 20 & 28 & 17 & $\mathbf{5}$ & - \\
\hline Limperis & 5 & 16 & 9 & 10 & 16 & 13 \\
\hline \multirow[t]{2}{*}{ Others } & 55 & 12 & 16 & 45 & 12 & 13 \\
\hline & 100 & 100 & 100 & 100 & 100 & 100 \\
\hline \multirow[t]{2}{*}{$\begin{array}{l}\text { Number } \\
\text { of Cases }\end{array}$} & & (346) & (135) & (237) & (101) & (98) \\
\hline & & \multicolumn{5}{|c|}{ Property Misdemeanors } \\
\hline \multicolumn{2}{|l|}{ Magistrate } & $\begin{array}{c}\text { April } 5-27 \\
\%\end{array}$ & \multicolumn{2}{|c|}{$\begin{array}{c}\text { April 28-June } 1 \\
\%\end{array}$} & \multicolumn{2}{|c|}{$\underset{\%}{\text { After June } 1}$} \\
\hline \multirow{6}{*}{$\begin{array}{l}\text { Wendt } \\
\text { Lee } \\
\text { Gill } \\
\text { Limperis } \\
\text { Others }\end{array}$} & & 6 & \multicolumn{2}{|r|}{12} & \multicolumn{2}{|r|}{16} \\
\hline & & 17 & \multicolumn{2}{|r|}{47} & \multicolumn{2}{|r|}{48} \\
\hline & & 39 & \multicolumn{2}{|r|}{23} & \multicolumn{2}{|r|}{19} \\
\hline & & 11 & \multicolumn{2}{|r|}{9} & \multicolumn{2}{|r|}{ - } \\
\hline & & 28 & \multicolumn{2}{|r|}{9} & \multicolumn{2}{|r|}{16} \\
\hline & & 100 & & 100 & & 100 \\
\hline \multicolumn{2}{|c|}{ Number of Cases } & (18) & & (43) & & (73) \\
\hline
\end{tabular}

ney was in effect screening out many of those arrests which may have been attributable, in part, to the confusion of the riot, rather than to serious criminal conduct on the part of the defendant. The young, however, were apparently not afforded the same treatment.

The apparent exercise of prosecutorial discretion in moving for dismissals was matched by magisterial discretion in deciding whether to convict and how to sentence. The data, even on the four magistrates we studied, show wide variations in judicial practices regarding riot misdemeanor defendants. Other magistrates exhibited still different patterns of disposition and sentencing of riot misdemeanor defendants. And, while none of the magistrates imposed sentences which were particularly severe, it should be noted that court records indicate that 21 convicted riot misdemeanants were forced to spend time in jail to work off fines. For some indigent defendants, even modest fines resulted in post-conviction incarceration. 


\section{B. Disposition: Felony Cases}

The preliminary hearing is unusually important in felony prosecutions in Illinois, because it marks the first stage at which the police decision to arrest is critically reviewed. In contrast with most other jurisdictions, the prosecutor in Illinois normally has little discretion in charging. Even during the riot, when the State's Attorney's office did establish the charging policy, it had little control over what arrests were made and which arrestees were formally charged. The pretrial screening function performed by the prosecutor in other jurisdictions is largely left in Illinois to the preliminary hearing. Only in that proceeding, after the charge has been determined, are spurious or doubtful felony cases dismissed.

Formally, a magistrate must find "probable cause" to believe that the defendant committed the offense with which he is charged to order that he be held over to the grand jury. The magistrate's decision, however, may rest on different considerations. According to Donald McIntyre, as a general rule magistrates apply a standard of "adequacy of evidence to support a conviction," and this standard may vary from charge to charge. ${ }^{269}$. When this evidentiary threshold is not met, McIntyre found that the magistrate either dismisses the charge or encourages reduction to a misdemeanor. Magistrates are inclined to dispose of felony cases at preliminary hearings, McIntyre asserts, because they know that "the single grand jury in Cook County, the ten judges who preside over felony trials, the limited personnel in the State's Attorney's office, and the heavily taxed jails and probation facilities can only handle about $20 \%$ of the cases." ${ }^{270}$ The magistrate's primary concern is to avoid the time, delay, and difficulty involved in full trials of felony cases. There is a systemic interest in disposing of felony cases at the earliest possible stage of prosecution.

Four-fifths of the felony cases in the sample McIntyre studied were disposed of at preliminary hearings. ${ }^{2 \pi 1}$ These cases either were dismissed on the basis of the preliminary findings, were reduced to misdemeanors and later heard on the merits in the Municipal Department, or were heard on the merits immediately, as the defendant waived his right to indictment and proceeded to trial before a judge of the Municipal Department. ${ }^{272}$ Most of these last two groups of

269 McIntyre, A Study of Judicial Dominance of the Charging Process, 59 J. Crim. L.C. \& P.S. 463,475 (1968).

$270 I d$. at $464-5$.

271 Id. at 464.

272 In Illinois all felony prosecutions must be by indictment unless waived understandingly by the accused in open court. ILL. REv. STAT. ch. 38, § 111-2(a) (1967). When the defendant waives his right to indictment, the method of prosecution is usually referred 
cases involved a plea bargain between the prosecution and the defense. The magistrate, because of the importance of his preliminary hearing determination, is able to review the appropriateness of a charge reduction involved in plea bargaining.

The riot arrestees charged with felonies were processed differently from normal felony defendants in the Municipal Department. The statistics show that their cases were much more likely to go to the grand jury for indictment than McIntyre's sample of normal cases. Seventy-two per cent of the riot felony cases but only one-fifth of those in McIntyre's sample were presented to the grand jury for indictment. Only $21 \%$ of the riot felony cases were dismissed at preliminary hearing, either on the motion of the State's Attorney or because the magistrate found no probable cause. (See Table 47.)

TABLE 47

Disposition of Felony Cases in Municipal Departmenta

\begin{tabular}{|c|c|c|c|c|c|c|c|}
\hline Disposition & $\begin{array}{c}\text { Property } \\
\text { Felony } \\
\%\end{array}$ & $\begin{array}{c}\text { Robbery } \\
\%\end{array}$ & $\begin{array}{c}\text { Felony } \\
\text { Against } \\
\text { Person } \\
\%\end{array}$ & $\begin{array}{c}\text { Arson } \\
\%\end{array}$ & $\begin{array}{c}\text { Weapons } \\
\%\end{array}$ & $\begin{array}{c}\text { Viceb } \\
\%\end{array}$ & $\begin{array}{r}\text { Total } \\
\%\end{array}$ \\
\hline Discharged & 8 & - & - & 14 & 27 & 15 & 5 \\
\hline Dismissed & 17 & 27 & 26 & - & 32 & 67 & 21 \\
\hline Convicted & 2 & - & - & 一 & 20 & 3 & 3 \\
\hline \multirow{3}{*}{$\begin{array}{l}\text { Held for } \\
\text { prosecutione }\end{array}$} & & & & & & & \\
\hline & 79 & 73 & 44 & 86 & 22 & 15 & 72 \\
\hline & 100 & 100 & 100 & 100 & $\overline{100}$ & $\overline{100}$ & 100 \\
\hline Number $=$ & (553) & (15) & (9) & (7) & (41) & (33) & (658) \\
\hline
\end{tabular}

a This table includes only those defendants charged with one felony. Due to difficulties in obtaining felony disposition data from court records, not all riot felony defendants are included.

b An undetermined number of persons charged with these offenses were prosecuted as misdemeanor defendants, rather than as felony defendants. That fact is reflected in the relatively high proportion of such cases disposed of at trial in the Municipal Department.

c The figures in this category may overstate slightly the percentage of felony cases held for prosecution in the Criminal Division. The formal disposition in the Municipal Department of riot cases held for further prosecution in the Criminal Division was usually nolle prosequi. Normally that disposition is used to indicate the reduction of a felony charge to a misdemeanor, or an outright dismissal, and a few of the riot cases which we have included in "held for prosecution" may in fact have been reduced or dismissed. See note 250 supra.

The vast majority of riot felony cases-84\%-involved property offenses. Ninety-four per cent of the property felony defendants were arrested for burglary. A comparison of our data on these property felo-

to as proceeding by information. Proceeding by information is most frequently used in narcotics offenses. 
ny defendants with a sample of normal burglary cases collected by McIntyre shows that the riot cases were much less likely to be disposed of at preliminary hearing than were normal burglaries. Only one-fifth of the riot property felony cases were discharged, dismissed, or reduced to a misdemeanor at preliminary hearings compared with two-thirds of McIntyre's sample. (See Table 48.)

TABLE 48

Disposition of Property felonies

\begin{tabular}{|c|c|c|}
\hline Disposition & $\begin{array}{c}\text { Riot } \\
\text { Property } \\
\text { Felonya } \\
\%\end{array}$ & $\begin{array}{c}\text { Normal } \\
\text { Burglaryb } \\
\%\end{array}$ \\
\hline Dismissal or discharge & 19 & 44 \\
\hline Reduction to misdemeanor & 2 & 22 \\
\hline \multirow[t]{2}{*}{ Held for further prosecutionc } & 79 & 33 \\
\hline & $\overline{100}$ & $\overline{100}$ \\
\hline
\end{tabular}

a See note a, Table 47 supra.

b Source: Sample of cases disposed of from January to May 1966, derived from McIntyre, A Study of Judicial Dominance of the Charging Process, 59 J. CRIM. L.C. \& P.S. 463 (1968).

c See note c, Table 47 supra.

The reason for this disparity is clear. In the preponderance of riot felony cases, a preliminary hearing was never held. In most cases, the State's Attorney decided to avoid the preliminary hearing and rely on the grand jury formally to determine probable cause in the first instance. ${ }^{273}$ Only $13 \%$ of the property felonies went before the grand jury at the order of a magistrate after a preliminary hearing.

The preliminary hearing is generally held in the same proceeding in which the defendant is advised of the charge against him and his right to counsel and admitted to bail. In some cases, where the State or the defense need additional time to obtain evidence or subpoena witnesses, continuances may be granted for two to three weeks. If the preliminary hearing is continued on the motion of the prosecution and the defendant has not made bond, a writ of habeas corpus will lie to obtain his release or compel an earlier preliminary hear-

273 McIntyre estimates that there are normally only 400 cases each year for which preliminary hearings are not conducted. These are primarily cases involving crime syndicate operators, indicted defendants on bond who commit another crime, situations where new evidence indicates the more serious nature of the oxiginal crime, or cases such as the fraudulent misuse of funds where it is desirable to avoid complicated multiple evidentiary presentations. Although the State's Attorney has no formal authority to proceed directly to an indictment after arrest, this procedure is regarded as part of his discretionary power. McIntyre, supra note 269, at 483 . 
ing. ${ }^{274}$ Despite the statutory requirement that a preliminary hearing be held, the Illinois Supreme Court has ruled that denial of a preliminary hearing is reversible error only if it actually prejudices the trial of the defendant. 275

The sample of bond hearing transcripts we studied indicates that even when preliminary hearings were held they did not take place when riot felony defendants first appeared in court but were continued until a later date. The Administrative Assistant to Chief Judge Boyle has said that preliminary hearings could not be held during the riot because the arresting officers were not available to testify.270

But preliminary hearings were not simply postponed until the officer could appear; in most cases, they were avoided entirely. The State's Attorney decided to present the riot cases directly to the grand jury without the benefit of prior magisterial review. The grand jury heard most of the cases in May; as a result, no probable cause determination was made for many defendants until more than a month after their arrests. Preliminary hearings were frequently continued again until the grand jury had returned an indictment and the case was docketed in the Criminal Court Division. At that time, the case was dropped in the Municipal Department.

Unlike the preliminary hearing, however, the grand jury proceeding is not an effective screening device. As Oaks and Lehman have shown, few cases are presented to the grand jury in Cook County which do not result in indictment. ${ }^{277}$ This was also true of the riot felony defendants. There were 751 cases $^{278}$ referred to the grand jury; it returned true bills in all but 13 cases.

274 Since the granting of the writ by a judge is discretionary, and since the judge has a reasonable time to decide the matter, the value of the writ in compelling a timely preliminary hearing is questionable. Practically, a motion for bond reduction hearing is a more effective device in getting a defendant released from custody.

275 People v. Petruso, 35 Ill. 2d 578, 221 N.E.2d 276 (1966). See also, People v. Bonner, 37 III. 2d 553, 229 N.E.2d 527 (1967).

278 Austin Committee files. Despite this straightforward statement with which our findings concur, one magistrate in an interview claimed preliminary hearings were conducted at bail hearings in all cases. Another magistrate maintained that an Assistant State's Attorney told him that the cases involved were on information and therefore preliminary hearings were not required. The term "information" is used not only to indicate that an indictment has been waived but also to indicate a form of prosecution initiated by the prosecutor's office. This latter method of prosecution is rarely used in Cook County since it is more cumbersome than the "complaint" procedure initiated by a private complainant or arresting officer. Almost all the riot cases were initiated by on-view arrest complaints signed by police officers.

277 OAKS \& LEHMAN 65 . In only $1 \%$ of the cases referred to the grand jury are nobills returned that result in the complete dismissal of all charges against the defendant.

278 These included 662 individual burglary charges, 6 arson, 16 grand theft, 4 attempted murder, 10 robbery, 9 weapons, and 4 aggravated battery. 
But riot cases were not unscreened by the State's Attorney before presentation to the grand jury. ${ }^{279}$ The State's Attorney established a grand jury preparations room in which several assistant state's attorneys reviewed each felony case before submitting it to the grand jury. Over 200 felony cases were dismissed or reduced to misdemeanor charges through this informal screening process. Only cases in which the State's Attorney was assured that the complainant was willing to testify and the arresting officer was able to identify the defendant were prosecuted in the Criminal Division. Only defendants who had been arrested inside the burglarized premises or within a short distance of the premises with goods clearly identifiable as having been stolen from particular premises were prosecuted on felony charges.

Despite avoidance of preliminary hearings and the ineffective screening role of the grand jury, therefore, riot felony cases were better screened and stronger evidentially than ordinary felony cases. Several factors appear to have persuaded the State's Attorney to adopt special screening procedures during the riot. First, it seemed to be the most efficient method. The Illinois four-term rule requires that defendants in custody be brought to trial within 120 days. ${ }^{280}$ Any delay in early screening procedures jeopardized subsequent prosecution. Secondly, it was believed that the informal screening procedure worked no greater hardship on defendants than preliminary hearings, most of which were being continued until long after the date of arrest anyway, presumably because arresting officers were needed on the streets and were unavailable to testify. Thirdly, the ordinary plea bargaining advantages of the preliminary hearing forum were largely absent under riot conditions. Many cases involved multiple defendants which, from the prosecutor's point of view, made plea bargaining with an individual defendant difficult. And with the advice of defense counsel, defendants were unwilling to plead guilty to a reduced charge in April or May when the proximity of the riot might result in harsh sentences. In fact, only about $2 \%$ of the property felony cases were reduced to misdemeanors before presentation before the grand jury. Under ordinary circumstances, $22 \%$ of burglary defendants are convicted on reduced charges. (See Table 48.)

Most important, however, was the feeling that magistrates acting under the political pressures and popular hysteria of the moment would lower probable cause standards to detain almost all of the arrestees. The State's Attorney's office would still be faced, therefore, with the task of dismissing or reducing evidentially weak cases.

279 The following discussion is based, in large part, on an interview with William J. Martin, April 26, 1969.

280 Ilc. Rev. Stat. ch. 38, \& 103-5 (1967). 
Although the State's Attorney's office decided soon after the riot to avoid preliminary hearings, several assistant state's attorneys, uninformed of the decision, presented cases for preliminary hearing. Most of these cases were held for further prosecution.

Final data on the disposition of riot felony cases in the Criminal Division are not available; 11 months after the riot, $19 \%$ of those indicted had not yet been tried. Of the 599 riot felony cases concluded by February 28, 1969, 70\% resulted in convictions. (See Table 49.) This compares with a 1967 conviction rate for all felonies of $61 \%$. It also compares extremely favorably with riot felony conviction rates in other cities. For example, in Los Angeles $79 \%$ of the felony arrestees from the Watts riot were convicted, but the majority of these convictions were on reduced charges; ${ }^{281}$ in Detroit, only two persons out of a sample of 1,630 were convicted of the felony with which they were originally charged. ${ }^{282}$

TABLE 49

Disposition of Riot and Normal felony Cases after INDICTMENT

\begin{tabular}{|c|c|c|}
\hline Disposition & Normal Casesa & Riot Cases \\
\hline Discharge or dismissal & $39 \%$ & $30 \%$ \\
\hline Found not guilty & $7 \%$ & $10 \%$ \\
\hline Nolle Prosequi & 7 & 2 \\
\hline SOL, SOL warrant, misc. & 25 & 19 \\
\hline Convicted & $61 \%$ & $70 \%$ \\
\hline Probation & 19 & $49 c$ \\
\hline Probation and jail & - & 11 \\
\hline House of Corrections & 12 & $2 \mathrm{~d}$ \\
\hline Cook County Jail, Vandalia & - & - \\
\hline Illinois State Penitentiary & 26 & 6 \\
\hline Fine & 2 & 1 \\
\hline Miscellaneous & 2 & - \\
\hline Number $=$ & $\begin{array}{r}100 \% \\
(4,486)\end{array}$ & $\begin{array}{l}100 \% \\
(599)\end{array}$ \\
\hline
\end{tabular}

a Source: Circuit Court of Cook County, Criminal Division, 1967 Annual Report.

b Source: Compiled by the Cook County State's Attorney's office. Includes cases concluded by February 28, 1969.

c Includes three cases for which restitution as well as probation was prescribed.

d Includes two cases in which fine was imposed in addition to time in the Cook County Jail.

The figures in Table 49 are somewhat misleading, however, since more than four-fifths of the riot felony cases which were dismissed were cases in which an SOL disposition was entered and a warrant

281 Klein, Ogren \& Thomas, Watts 1965: Arrests and Trials: Analysis and Statistics, 3 L. IN Trans. Q. 177 (1966).

282 Grockett, Recorder's Court and the 1967 Civil Disturbance, 45 J. Urban LAW 841, 847 (1968). 
for arrest entered as a result of a defendant's failure to appear at trial. ${ }^{283}$ If the SOL warrant cases are excluded from the sample, $85 \%$ of the riot felony defendants were convicted on the felony charged.284

Despite the higher conviction rate among riot felony defendants than among normal post-indictment felony defendants, a slightly greater precentage of the riot cases resulted in discharge at trial than is normal-10\% of the riot defendants compared with $7 \%$ of the 1967 felony defendants. The higher conviction rate among riot defendants reflects, therefore, a higher guilty plea rate. Although the normal guilty plea rate among post-indictment cases is high-in 1967 nearly $84 \%$ of those convicted pleaded guilty to the charge for which they were indicted ${ }^{285}$ - the State's Attorney's office indicated that an even higher proportion of the riot felony defendants pleaded guilty to the offense charged. But, as Table 49 suggests, riot felons may have been sentenced more leniently than normal felons. Seventy per cent of the convicted riot felons were sentenced only to probation, usually for two, three, or five years. ${ }^{286}$

The Kerner Commission was sharply critical of the prosecution of riot arrestees in Detroit and other cities. ${ }^{287}$ By adopting more careful charging and screening policies, and, perhaps relatively lenient sentence policies, the Cook County State's Attorney avoided the low conviction rate and much of the administrative breakdown which characterized the prosecution of riot defendants in other cities. But it is important to note that most felony defendants received no formal probable cause hearings. For a variety of reasons, neither preliminary hearings nor grand jury proceedings could be relied upon as effective screening procedures.

Most felony defendants were not even informally screened by the State's Attorney's office until a month or so after their arrest. ${ }^{288}$

283 "SOL warrant" indicates that a warrant for the defendant's arrest has been issued, but normally no concerted effort to take the defendant into custody is made. Until he is rearrested his case is "SOL'd" in the Criminal Division.

284 If the SOL warrant cases are excluded from the 1967 data, the overall conviction rate would undoubtedly also rise. But we have no information on the number of SOL warrants included in the 1967 data.

285 AdMInistrative OfFice of the Illinols Courts, 1967 ANNuAL RePort 55 (1968).

286 In large part, however, the apparent leniency may be explained by the difference in the charges on which convictions were obtained. Ninety-four per cent of the riot indictments were for burglary or unarmed theft, compared with only one-fourth of those convicted of felonies in 1967. Many of the 1967 felony convictions were for more serious charges.

287 KERNER COMMISSION REPORT 184.

288 The State's Attorney's office handled the riot cases in a generally professional manner. It is not at all certain that similar policies will prevail in the future, State's Attorney John Stamos, who was in office during the April 1968 riot, was not slated by the Cook 
And judicial review of most misdemeanor arrests was automatically continued until weeks after the riot. In the meantime, for many defendants, the significant sanctions of the criminal system had already been imposed. Many had been required to make numerous court appearances in the Municipal Department. And many had already served considerable lengths of time in jail. In the next section we shall explore more fully the rationale of pretrial detention.

County Democratic Party for reelection. He is presently serving on the Circuit Court of Cook County. William J. Martin, Assistant State's Attorney in charge of the prosecution of the April 1968 riot cases, is now Assistant Professor of Law at Northwestern University. 


\section{Preventive Detention}

In a previous section we saw how bail, though set at approximately normal levels in felony cases, resulted in the detention of many defendants until the rioting subsided. In this section we examine the problem of temporary detention during civil disorders. We begin with the fact that ordinary bail practices may be, and are in fact, used to achieve temporary detention both under normal circumstances and during civil disorders. We consider the costs of detaining arrestees through high bond amounts, and the special circumstances which may justify preventive detention during civil disorders. We then turn to an analysis of three approaches to the establishment of an express authorization of preventive detention during civil disorders. Finally, we briefly explore the problem of detention in light of the present overall operation of the criminal system.

\section{A. Bail Practice and Pretrial Detention}

1. Generally. Whether or not there is a constitutional right to bail is unresolved. While most commentators interpret the eighth amendment bail clause as implying a right to bail, ${ }^{289}$ it would appear by virtue of federal and state statutory authorizations of denial of bail in capital offenses, ${ }^{200}$ that the right to bail is subject to some restriction.

289 "Excessive bail shall not be required, nor excessive fines imposed, nor cruel and unusual punishments inflicted." U.S. CoNsT. amend. VIII.

The most comprehensive argument that the bail clause confers a right to bail can be found in Foote, The Coming Constitutional Crisis in Bail: I, 113 U. PA. L. REv. 959, 969-71 (1965). Logically, a right to bail can be found in the fact that

It would be anomalous to assume that the eighth amendment, while prohibiting the de facto denial of release through the imposition of excessive bail, leaves the way open for legislative elimination of the right to bail. Thus, in order to give effect to what must have been the framers' intention, it should be concluded that the excessive bail prohibition guarantees by implication some right to bail.

Note, Preventive Detention Before Trial, 79 HARv. L. REv. 1489, 1499 (1966). See also United States v. Motlow, 10 F.2d 657, 659 (Butler, Circuit Justice, 1926) (dictum); Trimble v. Stone, 187 F. Supp. 483, 484-5 (D.D.C. 1960); Punishment Before Trial, 48 J. AM. JuD. Soc'x 6, 7 (1964) (quoting address by Chief Justice Warren to 1964 National Conference on Bail and Criminal Justice).

It is now generally assumed that the bail clause is applicable to the states. See In re Shuttlesworth, 369 U.S. 35 (1962); Mastrian v. Hedman, 326 F.2d 708, 711 (8th Cir.), cert. denied, 376 U.S. 965 (1964).

290 See 18 U.S.C. $\$ \S 3146,3148$ (Supp. II, 1967). For the proposition that the eighth amendment does not guarantee a right to bail, see Mastrian v. Hedman, 326 F.2d 708, 710 (8th Cir.), cert. denied, 376 U.S. 965 (1964): "Traditionally and acceptedly, there are offenses of a nature as to which a state properly may refuse to make provision for a right to bail." The leading Supreme Court case on bail discusses it in the context of a statutory rather than a constitutional right. See Stack v. Boyle, 342 U.S. I, 4 (1951). 
Like other Bill of Rights guarantees, the right to bail is probably subject to reasonable legislative restrictions, but such restrictions, in the case of a criminal defendant pending trial, have not been extended beyond protecting the public interest in an orderly judicial process-usually to assure appearance in court. ${ }^{201}$

Regardless of the constitutional status of restrictions on the right to bail, the Federal Bail Reform Act and most state statutes provide that bail shall be set in order to assure the defendant's appearance in court. Setting high bail for the purpose of detaining an accused is clearly unauthorized under most statutes. ${ }^{202}$

Nonetheless, the lower courts often resort to bail to effect pretrial

291 The risk of flight would appear greatest in the case of a capital offense. See Mastrian v. Hedman, 326 F.2d 708, 712 (8th Cir.), cert. denied, 376 U.S. 965 (1964); State v. Konigsberg, 33 N.J. 367, 373, 164 A.2d 740, 743 (1960); People ex rel. Lobell v. McDonnell, 296 N.Y. 109, 71 N.E.2d 423 (1947). The notion that risk of flight is part of a larger public interest in the orderly functioning of the judicial process would reconcile the few opinions which have upheld denial of bail because of the danger that the defendant would intimidate witnesses. Note, Preventive Detention Before Trial, supra note 289, at 1502-3.

On the other hand, future dangerousness as a reason for denying bail has been upheld pending appeal of a criminal conviction (Leigh v. United States, 82 S. Ct. 994, 996 (Warren, Circuit Justice, 1962); Carbo v. United States, 82 S. Ct. 662, 669 (Douglas, Circuit Justice, 1962); United States v. Martone, 283 F. Supp. 77, 81 (D. Puerto Rico 1968); 18 U.S.C. § 3148 (Supp. II, 1967)) (allowing denial of bail pending appeal if the defendant poses "a danger to any other person or to the community"), as well as under certain civil detention statutes. See Carlson v. Landon, 342 U.S. 524, 542 (1952) (aliens pending deportation hearings); Minnesota ex rel. Pearson v. Probate Court of Ramsey County, 309 U.S. 270 (1940) (sexual psychopaths); Greenwood v. United States, 219 F.2d 376 (8th Gir.), aff'd, 350 U.S. 366 (1955) (mentally incompetent persons); In re Magnuson, 110 Cal. App. 2d 73, 242 P.2d 362 (1952) (juveniles); State ex rel. Sweezer v. Green, 360 Mo. 1249, 232 S.W.2d 897 (1950) (sexual psychopaths). It has been argued, however, that these instances are based on a rationale fundamentally inapplicable to preventive detention of normal criminal defendants prior to conviction:

[T] he theory [behind the detention] is that, because of some mental or emotional abnormality, these people are not responsive to the deterrence provided by the threat of criminal sanctions and cannot be dealt with through the usual process of the criminal law.

Note, Preventive Detention Before Trial, supra note 289 at 1504.

292 See 18 U.S.C. $\$ \S 3146-52$ (Supp. II, 1967). A right to bail similar to the federal statute exists in all but seven states. See, e.g., Ill. CoNSr. art. II, § 7; InL. Rrv. Srat. ch. 38 , $\S 110-1$ to -15 (1967). Bail in an amount necessary to assure appearance at trial as the standard for reasonable bail has been upheld in Stack v. Boyle, 342 U.S. 1, 4-5 (1951). See also Bandy v. United States, 81 S. Ct. 197 (Douglas, Circuit Justice, 1960); United States v. Foster, 278 F.2d 567 (2d Cir. 1960); Heikkinen v. United States, 208 F.2d 738 (7th Cir. 1953). Similar limitations have been imposed on state courts. Gusic v. Boies, 72 Ariz. 233, 233 P.2d 446 (1951); In re Newbern, 55 Cal. 2d 500, 360 P.2d 43, 11 Cal. Rptr. 547 (1961); People ex rel. Sammons v. Snow, 340 IIl. 464, 173 N.E. 8 (1930); State v. Clark, 234 Ia. 338, 341, 11 N.W.2d 722, 724 (1943), cert. denied, 323 U.S. 739 (1944); State v. Bentley, 46 N.J. Super. 194, 134 A.2d 445 (1957); People ex rel. Lobell v. McDonnell, 296 N.Y. 109, 71 N.E.2d 423 (1947); In re Cremati, 99 Ohio App. 402, 117 N.E.2d 440 (1954). 
detention. $^{203}$ The most common explanation for this practice is the need to protect society by detaining arrestees thought to pose a threat to public safety. Such threats include tampering with evidence or threatening witnesses, ${ }^{294}$ habitual or compulsive criminal behavior, ${ }^{295}$ and the danger that a defendant is likely to cause injury to someone or threaten the physical safety of the public. ${ }^{296}$

A second, though less frequently articulated, explanation rests on the inability of the lower criminal courts to handle large numbers of criminal cases efficiently. In order to avoid trial litigation, which would overburden the system, courts rely on pretrial detention to induce guilty pleas. ${ }^{297}$ In order to avoid the administrative impracticality of time-consuming individualized bail hearings, magistrates make mechanical determinations and set uniform bond amounts which are often prohibitively high, to avoid risking release of large numbers of arrestees. ${ }^{298}$

A third explanation, also seldom articulated, is based on punitive and deterrent motives reflected in the practice of giving minor offenders "a taste of jail,"299 particularly where courts' leniency with first offenders, and other factors, result in suspended sentences, pretrial dismissals, or probation. ${ }^{300}$

It is important to recognize that the latter two explanations are not, like the first, related to preventive purposes, but refer respectively to administrative needs and to punitive and general deterrent pur-

293 The sub rosa practice of detention through setting high bail is discussed in D. Freed \& P. Watd, BaIl in the United States: 1964, at 49-55 (1964); National Conference on Bail and CrIminal Justice, Proceedings and Interm Report 201-3, 212-3 (1965) [hereinafter cited as National Conference on BaIL]; Note, Compelling Appearance in Court: Administration of Bail in Philadelphia, 102 U. PA. L. REv. 1031, 1038-40 (1954) [hereinafter cited as Philadelphia Bail Study].

294 National Conference on BaIl 152-4; Comment, Preventive Detention, 36 Geo. WASH. L. REV. 178, 179-80 n.13 (1967).

295 National Conference on Ball 152-4; Comment, Preventive Detention, supra note 294, at 179 .

296 I Report of the President's Commission on Crume in the District of Columbia 527 (1966) [hereinafter cited as D.C. GrIme Commission REPorT]. See also ALI Code Grim. Procedure \$ 70 (1931); ABA Project on Minimum Standards for Criminal Justice, Standards Relating to Pretrial Release 83 (1968) [hereinafter cited as ABA Pretrial RzIEASE STANDARDS]; Foote, Twelve Judicial Views on Bail, in Hearings on S. 1357, S. 646, S. 647, and S. 648 Before the Subcomm. on Constitutional Rights and the Subcomm. on Improvements in Judicial Machinery of the Senate Comm. on the Judiciary, 89th Cong., Ist. Sess. 298 (1965).

297 See Packer, Two Models of the Criminal Process, 113 U. PA. L. REv. 1, 38 (1964). 298 See Philadelphia Bail Study 1036-43; Note, A Study of the Administration of Bail in New York City, 106 U. PA. L. REV. 693, 707, 712-5 (1958) [hereinafter cited as New York Bail Study].

299 See, e.g., New York Bail Study 705.

300 See Packer, supra note 297, at 39. 
poses. But the problem has, to date, been discussed as if it were solely one of preventive detention. We will return to this problem at the end of this section.

A variety of reasons suggest that today's sub rosa use of bail as a tool for effectuating unauthorized policies of pretrial detention is unfortunate. The use of bail for purposes of pretrial detention forecloses any opportunity to check magisterial abuse. In the absence of statutory criteria for establishing future dangerousness, bail determinations intended to implement preventive detention can only be measured against statutory standards designed to assure appearance in court. ${ }^{301}$ Unarticulated findings of dangerousness cannot be rebutted. ${ }^{302}$ Moreover, bail determinations are not subject to effective review. They are not accompanied by written opinions, and the wide discretion given the bailsetting judge precludes reversal of a bail determination unless it is "beyond the range within which judgments could rationally differ in relation to the apparent elements of the situation." 303 In reality, the principal limitation on bailsetting is a magistrate's sense of self-restraint. ${ }^{304}$

There are also practical difficulties in obtaining review of bail. A defendant may be brought to trial before his appeal from the bail determination is heard, thereby mooting his claim. ${ }^{305}$ In Illinois the Public Defender does not customarily appeal bail determinations of indigent defendants. ${ }^{306}$ Federal habeas corpus relief is unlikely, because "the question in the federal court will rarely be a substantial one unless the discretionary judgment has not been exercised in the state courts." ${ }^{30 \tau}$ Consequently, state habeas corpus relief may be the only feasible means of review, and that form of relief may also be too slow to protect defendants' interests. ${ }^{308}$

A defendant's remedy for pretrial detention is said to be a motion for expedited trial, ${ }^{309}$ which puts a burden on a defendant's right

301 For the statutory standards, see, e.g., FED. R. CRRM. P. 46(c) (superceded by 18 U.S.C. $\$ \S 3146,3148$ (Supp. II, 1967)), upheld in Stack v. Boyle, 342 U.S. 1, 5 (1951); Yocca v. Ogilvie (Ill. Sup. Ct. Feb. 5, 1964) (unreported) in Kamin, supra note 105, at 683-4.

302 Comment, Preventive Detention, supra note 294, at 179.

303 Mastrian v. Hedman, 326 F.2d 708, 711 (8th Cir.), cert. denied, 376 U.S. 965 (1964). See also Gusick v. Boies, 72 Ariz. 233, 233 P.2d 446 (1951); In te Morehead, 107 Cal. App. 2d 346, 287 P.2d 385 (1951).

304 See New York Bail Study 705.

305 See, e.g., M. Patner, Appointed Counsel's Guide for Illinois Griminat Appeals 23 (1968).

306 Cawley Testimony 231.

307 Brown v. Fogel, 387 F.2d 692, 694 n.l (4th Cir. 1967).

308 See Foote, The Coming Constitutional Crisis in Bail: II, 118 U. PA. L. REv. 1125, 1176-7 (1965) [hereinafter cited as Foote II].

300 See United States v. Rumrich, 180 F.2d 575 (2d Cir. 1950). 
to trial by jury. ${ }^{310}$ Moreover, a detained defendant's preparation for expedited trial is likely to be impaired by his inability to locate witnesses and other factors. ${ }^{311}$

Finally, money bail amounts are an irrational means of detaining presumably dangerous persons. ${ }^{\mathbf{3 1 2}}$ Since ability to make bail bears no necessary relation to a defendant's potential dangerousness, both dangerous and non-dangerous poor defendants who cannot make bail are detained, while the rich and possibly dangerous defendant goes free. ${ }^{313}$

But, as one commentator has noted:

If the present system of requiring bail for some reason or other stopped producing a high rate of pretrial confinement, it would have to be replaced by one that did..$^{314}$

In light of that fact and the shortcomings in the use of bail for preventive detention purposes, commentators have examined the possibilities of an overt preventive detention scheme.315 An express preventive detention scheme may have the additional virtue, by removing the necessity for relying on monetary bail to achieve detention, of paving the way for much needed bail reform measures. ${ }^{316}$

310 Comment, Preventive Detention, supra note 294, at 185-6.

311 See generally Wald, Foreward to Pretrial Detention and Ultimate Freedom: A Statistical Study, 39 N.Y.U.L. Rev. 631, 633 (1964); Rankin, The Effect of Pretrial Detention, 39 N.Y.U.L. REv. 641 (1964). See also Ares, Rankin \& Sturz, The Manhattan Bail Project: An Interim Report on the Use of Pre-Trial Parole, 38 N.Y.U.L. REv. 67, 90 (1963) [hereinafter cited as Manhattan Bail Project]; ATTORNEy General's CoMmITTEE on PoverTy aNd the Administration of Federal Criminal Justice, Report 70-71 (1963) [hereinafter cited as ATTORNEY General's CommitTEE]; Foote II, at 1140-8.

312 The same criticism has been made of the bail system generally, suggesting that risk of financial loss is neither necessary nor sufficient to assure appearance in court. See FREED \& WALD, supra note 293, at 9-21.

313 Comment, Preventive Detention, supra note 294, at 179.

314 Packer, supra note 297, at 41.

315 See, e.g., Foote II, at 1125; Comment, Preventive Detention, supra note 294, at 178; Note, Preventive Detention Before Trial, supra note 289, at 1489; D.G. CRIME Commissron Report 513-29; ABA Pretrial Release Standards 83 ff. Current interest in a preventive detention statute is reflected in the debate surrounding President Nixon's 12-point program to combat crime in the District of Columbia, including a recommendation that "dangerous" criminals be held without bail while awaiting trial. 27 ConG. Q. 214 (Weekly Report) (1969).

For a comparison with the overt practices in other countries, see Bratholm, Arrest and Detention in Norway, 108 U. PA. L. Rev. 336 (1960); Keane, Preventive Justice, 2 IRISK JUR. 233 (1967); Mostyn, Bail and the Presumption of Innocence; England and America: A Comparison, 61 L. Soc. GAZ. 799 (1964); Smith, Bail Before Trial: Reflections of a Scottish Lawyer, 108 U. PA. L. REv. 305 (1960).

316 For a discussion of the bail system in general, see FREED \& WALD, supra note 293; Note, Bail: An Ancient Practice Reexamined, 70 YALE L.J. 944 (1961). See also A. BEELEY, The BaIl. System in Chicago (1927), a pioneer study, many of whose findings are valid today.

Criticisms of bail practices as well as proposals for reform and alternatives to the pres- 
Those who have considered the overall merits of an express preventive detention system have been reluctant, however, to recommend its application in ordinary circumstances. Some studies indicate that the risk a defendant released on bail will commit subsequent crimes is much lower than many judges have assumed. ${ }^{317}$ But because accurate means of predicting future dangerousness have not been developed, many fear that legislation authorizing preventive detention in normal times could not be written carefully enough to insure accurate and narrow application. ${ }^{318}$ Too many people would be detained, and some dangerous defendants might not be held at all. ${ }^{319}$ Moreover, application of accurate measures and strict guidelines, even if they could be provided, would be self-defeating, since it would result in prolonging both initial bail determinations and review. ${ }^{320}$ In fact, to the extent that both non-individualized hearings and delay reflect structural deficiencies in the lower criminal courts, a preventive detention scheme would suffer many of the same defects of current bail practice.

Still others consider that untested alternatives less drastic than pretrial detention may adequately protect society from the dangers of release, ${ }^{321}$ particularly when weighed against the hardships which de-

ent system are examined in Foote II, at 1125; New York Bail Study 693; Philadelphia Bail Study 1031; Attornex Generaz's Commirtiee 58-124; ABA Pretrial Release StanDARDS 31-55. The use of bail as a means of harassing civil rights workers is discussed in Wizner, Bail and Civil Rights, 2 L. IN Trans. Q. 111 (1965).

For a discussion of bail reform projects, see Manhattan Bail Project 67; Kamin, supra note 105. The success of ROR projects and an examination of the desirability of using ROR are reported in NATIONAL Conference on BAIL 33-148.

The Federal Bail Reform Act, 18 U.S.C. \$§ 3146-52 (Supp. II, 1967), is evaluated in D.C. CrIme Commission 504-29. See also Ill. REv. Stat. ch. 38, §§ 110-1 to -15 (1967); Bowman, The Illinois Ten Per Cent Bail Deposit Provision, 1965 U. ILL. L.F. 35 (1965).

The reluctance of courts to utilize bail reform measures is discussed in ABA PrETRIAL RELEASE STANDARDS 55-7.

317 See Foote II, at 1169-72; Note, Preventive Detention Before Trial, supra note 289, at $1496-7$.

318 See Foote II, at 1172-4; Note, Preventive Detention Before Trial, supra note 289, at 1506-7; New York Bail Study 706; ABA Pretrail Release Standards 6-7, 68-70; PresYDENT's Commission on LAw Enforgement and Administration of Justice, The Challenge of CRIME IN A FREE SocIETy 131 (1967) [hereinafter cited as PrEsident's CRIME CoMimission REPORT].

319 See Mostyn, supra note 315, at 799-800; Paulsen, Pre-trial Release in the United States, 66 Colum. L. Rev. 109, 125 (1966); Colista \& Domonkos, Bail and Civil Disorder, 45 J. URBAN L. 815, 822 (1968).

320 "The more precise the standards for preventive detention are made, the more will be required of the prosecution to establish a case for detention, with corresponding increase in the complexity of the fact finding process." Foote $I I$, at 1175. See id. at 1176-80.

321 Such alternatives include conditional release restricting travel, associations, or activities, release to the custody of a parole officer or other third party, rearrest and detention on violation of conditions, and daytime release. See generally Bail Reform 
tention imposes on "legally innocent" defendants. ${ }^{322}$ The propriety of preventive detention obviously involves a balancing of the risks to society and the rights of arrestees. Most examinations have concluded that under ordinary conditions the "calculated risk" to society posed by releasing arrestees is only a small part of the total "price of our system of justice."323

2. During Civil Disorders. One may accept the conclusion that preventive detention is undesirable under ordinary circumstances and nevertheless believe that extraordinary conditions during periods of civil disorder require a recalculation of the risk to society of releasing arrestees. ${ }^{324}$ During both the Detroit and Chicago riots, bail magistrates and others apparently felt that increased social risks required pretrial detention. The initial response of many Detroit and Chicago judges to riot conditions was to set high bail "so as to frustrate release." 325 Mass arrests and temporary detention were justified as necessary to clear the streets, 328 "break the back of the rioting," 327 "provide a threat to potential riot participants and hence a deterrent to continued rioting," 328 prevent arrestees from "returning to the scene," 329 and avoid the "danger of contempt replacing respect ... [which would lead to] new acts of lawlessness." 330 Again, as with the use of temporary detention under normal conditions, it is evident that reasons based on prevention of unlawful conduct must be distinguished from those grounded in punishment and general deterrence.

It is exceedingly difficult to determine whether the threat posed by riot conditions justifies the use of preventive detention, because it is

Act, 18 U.S.G. $\$ \$$ 3146-52 (Supp. II, 1967); President's CrIme Commission Report 131-2; ABA Pretrial Release Standards 70-74.

322 For a general discussion of the hardships imposed on the defendant by detention, see The President's Commission on LAw Enforcement and ADMinistration of Justice, TASK Force Report: The Courts 38 (1967) [hereinafter cited as TASK Force Refort: the Courts]; ATtorney General's Commitree 70-77; Freed \& WALD, supra note 293, at 39-48.

323 Stack v. Boyle, 342 U.S. 1, 8 (1951). See Foote II, at 1170-1.

324 Such a reevaluation in the context of riots has been suggested in a study of the 1967 Detroit disorders. The study noted that the Kerner Commission's rejection of preventive detention was based on the recommendations of the President's Commission on Law Enforcement and Administration of Justice which evaluated the scheme in the context of ordinary conditions. Colista \& Domonkos, supra note 319, at 821-3. See Kerner Commission Report 186, 192 n.24; President's Crime Commission Report 131-2. 325 KERNER COMMISSION REPORT 185. In some instances, the practice was not even sub rosa but involved an out-and-out refusal to accept bonds. $I d$. at $185 \mathrm{n} .7$.

326 See 1 BNA Crim. L. RPtr. 2286 (Aug. 16, 1967); Kerner Commission Report 184. 327 Colista \& Domonkos, supra note 319 , at 819.

328 Id. at 819 , citing a pronouncement by a Detroit judge.

329 Rueger, Riot Panel, 3 The Prosecuror 282, 287 (1967).

330 Cahalan, The Detroit Riot, 3 THE Prosecutor 430, 432 (1967). 
almost impossible to calculate the risk to the public of releasing defendants during civil disorders. Partly because judges have practiced $s u b$ rosa preventive detention through setting high bail and have not experimented with releasing arrestees thought likely to commit dangerous acts, we lack knowledge of the effectiveness of standards for detention even under normal conditions. ${ }^{331}$ Almost nothing is known about criminal repeaters during civil disorders, ${ }^{332}$ and rearrest would seem to be an unreliable measure of recidivism during riots. ${ }^{333}$ The inability to predict accurately the consequences of releasing arrestees in riot situations only adds to the reluctance of magistrates to release rioters on low bail.

This reluctance may be encouraged by certain factors peculiar to riots. Even if the percentage of arrestees likely to engage in lawless activity on release is no greater than under normal conditions, ${ }^{334}$ the sheer number of people arrested might make that percentage significant. ${ }^{335}$ And given the nature of crowd behavior, the interactive effect of releasing even a small number of people in a densely populated area ${ }^{336}$ distinguishes the risk from that occasioned by release in normal times.

Second, since many participants in past riots have been ordinarily law-abiding citizens, ${ }^{337}$ it may seem that the risk of reentry into the riot is substantially greater than that of ordinary criminal conduct. ${ }^{338}$

\footnotetext{
331 See authorities cited supra note 318.

332 Participation in riot activity by many young citizens without prior criminal records (see note 337 infra) indicates that standards of prediction based on past behavior may be irrelevant to the detention decision. Moreover, the relatively large numbers of ghetto residents who lack financial resources, lack roots in the community, and have prior arrest records because of conditions of discrimination and poverty raise questions about the fairness of ordinary standards of prediction.

333 See Colista \& Domonkos, supra note 319, at 823-4.

334 For an analysis of the risk of release under normal conditions, see Foote $I I$, at $1170-1$.

335 Colista \& Domonkos, supra note 319, at $823-4$.

$330 I d$.

337 The non-criminal character of many riot participants is indicated by various studies of the riots. The Kerner Commission found that much looted merchandise was returned after the Detroit riot. KERNER COMMrssion REPORT 190. Of 3,927 people arrested in the Watts riot, over half had no record of prior convictions. PRESDENT's

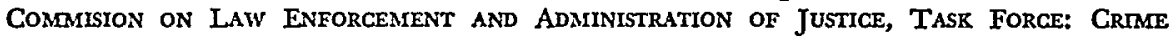
AND Its IMPACT-AN AssessMent 120 (1967 [hereinafter cited as TASK Force REPORT: AssESSMENT]. A survey of Newark riot arrestees revealed that less than $45 \%$ had police records. KERNER COMMISSION REPORT 190 n.17. These figures are particularly significant in light of the estimate that a Negro male who grows up in the slums has a $75 \%$ chance of being arrested in his lifetime. TASK FORCE REPORT: ASSESSMENT 120, citing M, E. Wolfgang, Grime and Race-Conceptions and Mis-Concertions 31 (1964).

338 On the other hand, the low incidence of riot arrestees with prior criminal records may indicate that preventive detention is unnecessary. For many such arrestees the mere
} 
Furthermore, feasible alternatives available to meet the ordinary risk of criminal conduct ${ }^{339}$ appear to be impracticable during a riot. ${ }^{340}$ Release on specified conditions or to the custody of a third partyalternatives which require court supervision-would seem impractical in light of the confusion and manpower shortages characteristic of judicial administration during civil disorders. Providing penalties for violating conditions of release or for rearrest on criminal charges would probably be ineffective, because the absence of adequate law enforcement in riot àreas would make rearrest unlikely. ${ }^{341}$ All of these factors may seem to justify the use of preventive detention as a tactic of riot control.

But it is also important to recalculate the costs of preventive detention under riot conditions. The difficulties of providing adequate safeguards during ordinary conditions ${ }^{342}$ to ensure both a narrow and accurate application of detention standards are magnified during periods of civil turmoil. The difficulty of accurately predicting the likelihood of subsequent riot-related conduct, together with the apparent disposition of judicial authorities to detain large numbers of people for deterrent and punitive reasons, reduces the possibility of significantly limiting judicial discretion and over-detention.

The abuses and hardships which result from temporary detention are radically magnified during civil disorders. Detention conditions are particularly dehumanizing during riots. In Detroit, some arrestees were held in underground garages or in buses without adequate food, water, and sanitation facilities; 343 the inadequacy of detention facilities in Chicago was described in Section IV above. Loss of earnings and employment resulting from only a few days' detention has a particularly crippling effect on economic and family relationships within an already economically depressed community. ${ }^{344}$

In addition, it is important to remember that many riot arrestees are young persons and minor offenders without prior criminal records. And the imposition of preventive detention on riot arrestees may only serve to aggravate existing resentment and hostility toward the criminal system. ${ }^{345}$ Hostility and cynicism toward the larger society "is rein-

fact of arrest and initial court processing may constitute sufficient deterrence to reentry. See Colista \&. Domonkos, supra note 319 , at 824 n.58.

339 See note 321 supra.

340 For a discussion of alternatives in the context of civil disorder, see KerNer CoMMISSION REPORT 192.

341 See Colista \& Domonkos, supra note 319 , at 823.

342 See notes 318-20 supra and accompanying text.

343 See KERNER CoMmission REPORT 184.

344 See id. at 71 ff., 73 ff.; Colista \& Domonkos, supra note 319, at 818.

$345 \mathrm{~A}$ composite picture of the "typical" rioter drawn by the Kerner Commission 
forced by a widespread perception ... of the existence ... of a 'double standard' of justice and protection-one for Negroes and one for whites." ${ }^{48}$ Complaints that the courts dispense "assembly-line justice" denying equal treatment to the poor and the affluent, and that bail procedures only further class inequities ${ }^{347}$ reveal deeply antagonistic feelings toward the criminal process.

The sub rosa use of bail for detention purposes undoubtedly appears to many ghetto residents to be a particularly obvious instance of unequal justice. ${ }^{348}$ But the switch to an overt preventive detention system would hardly reduce feelings of distrust toward the system. In fact, the authorization of preventive detention may only aggravate existing resentments.

But whether or not the disadvantages of an overt preventive detention scheme outweigh its desirability in times of civil disorder, it is apparent that magistrates and judges expressly approve of and practice preventive detention during civil disorders and will in all likelihood continue to disregard constitutional and statutory prohibitions against its use. A frank recognition of this insistence on using detention as a riot control tactic has led some commentators to examine the possibility that an overt scheme with reasonable guidelines might result in fewer detentions during riots than have resulted from the sub rosa use of bail to effect detention. They see statutory authorization for the use of preventive detention during riots as a means of assuring both incarceration of truly dangerous defendants and the rapid release of about $80 \%$ of those arrested ${ }^{349}$ through use of bail reform alternatives. We shall turn now to consideration of three different approaches to the problem of preventive detention during civil disorders.

B. Legal Approaches to Preventive Detention Under Riot Conditions

1. The Flexible Guarantees Rationale. One approach to the problem of preventive detention, outlined recently in the Columbia Law Review, builds on the premise that "[m]any constitutional rights are flexible enough to permit unusual procedures in time of riots." 350

reveals a strong distrust of the political system and intense perceptions of victimization resulting from racial discrimination. KERNER COMMISSION REPORT 73-74.

346 Id. at 98.

347 Id. at 183. Three-quarters of the cities surveyed by the Kerner Commission revealed significant grievances involving the administration of justice. $I d$. at 82.

348 "A defendant's attitudes are crystallized in prison, where the most obvious lesson of the pretrial period is that if you have money you go out, i.e., that justice is for sale. Those familiar with detention prisons are aware that this cynical attitude dominates the value culture of the jail." Foote $I I$, at 1148 .

349 See Colista \& Domonkos, supra note 319, at 826.

350 Note, Riot Control: the Constitutional Limits of Search, Arrest and Fair Trial Procedure, 68 Colum. L. REV. 85, 115 (1968). 
Preventive detention may be based, under this view, on present statutory exceptions to the right to bail ${ }^{351}$ which state legislatures might extend to deny bail to riot arrestees if compelled by public necessity. ${ }^{352}$ Safeguards would be provided by requiring the prosecution to establish at the preliminary hearing both the probability of guilt and the necessity for detention. A detention order would expire after two days, requiring the state to meet its burden again in order to justify an extension of the order. ${ }^{353}$

This approach attempts to steer a middle course between two unpalatable alternatives. On one hand, it is feared that "[i]f the courts do decide that necessary measures are barred by the Constitution, the case for. using martial law to avoid the Constitution's effect will become much stronger." ${ }^{354}$ On the other hand, it is thought that the present bail system is too inflexible to accomplish temporary detention with minimal abuse.

The major weakness of the proposal is the long-term effect it may have on our system of constitutional guarantees. Creating flexibility in constitutional standards raises the danger of ultimate encroachment upon long-established guarantees which, though subject to abuse in practice, have the virtue of remaining benchmarks against which current practice must ultimately be evaluated. It may be argued that "Americans have long trusted their judges to distinguish necessary from unnecessary encroachments on liberty," and that "the principle that what is permissible during a riot may be impermissible at other times is one that courts can apply." ${ }^{555}$ But some "other times" too may present unique dangers. While a riot may be the most familiar type of crisis presently threatening civil peace, other less volatile but still dangerous circumstances can easily be envisaged which might provide similar justification for further extending "exceptional" limitations on pretrial release, once those limits are extended for riots.

Furthermore, this "exception" is not, as the author of the note seems to suggest, merely another in the tradition of existing exceptions to bail, as where the risk of flight is great, ${ }^{356}$ or pending appeal, ${ }^{357}$ or to

\footnotetext{
351 E.g., in the case of previously convicted felons, N.Y. CODE CRIM. Proc. § 552(3).

352 Note, Riot Control, supra note 350 , at 104 .

353 Id.

354 Id. at 110.

355 Id. at 111 .

356 See Stack v. Boyle, 342 U.S. 1, 4-5 (1951); Note, Preventive Detention Before Trial, supra note 289 , at 1492 .

357 See Rehman v. California, 85 S. Ct. 8 (Douglas, Circuit Justice, 1964); Carbo v. United States, 82 S. Ct. 662, 668 (Douglas, Circuit Justice, 1962); Ward v. United States, 76 S. Ct. 1063 (Frankfurter, Circuit Justice, 1956); 18 U.S.C. \& 3148 (Supp. III, 1968).
} 
effect civil detention. ${ }^{358}$ Denial of bail to a riot arrestee would be the first exception based on the risk of future dangerous conduct of a competent adult criminal defendant prior to an adjudication of guilt..$^{359}$ This new "extension" involves a difference in kind whose rationale is in tension with the foundations of our criminal system-the presumption of innocence, and the notion that detention prior to adjudication of guilt except for those incapable of responding to the threat of ordinary sanctions is justifiable only where it serves to protect rather than displace the trial process.

In attempting to strengthen its constitutional justification, the proponents of the "flexible guarantees" approach may ultimately weaken the foundations of those guarantees. The present bail system, while subject to abuse during normal conditions and to breakdown during tiots, has the advantage of maintaining constitutional safeguards, at least in theory.

2. The Martial Law Rationale. Perhaps the clearest rationale for preventive detention is found in cases approving executive actions pursuant to express or implied declarations of emergency. ${ }^{360}$ Whereas the flexible guarantees concept attempts to accommodate expansions of the police power and the Bill of Rights, martial law contemplates an express or de facto executive declaration of emergency rather than a judicial finding of "special circumstances" as the basis for limiting Bill of Rights guarantees. ${ }^{361}$ While both approaches assume the existence of extraordinary public danger, the initial limitations are imposed by the courts in the first model and by an executive officer in the second.

The martial law approach has been recently advocated by Lawrence Hyde, Dean of the National College of State Trial Judges. Recognizing

358 See Greenwood v. United States, 219 F.2d 376 (8th Cir. 1955), aff'd., 350 U.S. 366 (1956); Craig v. Steele, 123 F. Supp. 153, 154-5 (W.D. Mo. 1954); In re Magnuson, 110 Cal. App. 2d 73, 242 P.2d 362 (1952); A.N.E. v. State, 156 So. 2d 525, 527-8 (Fla. Dist. Ct. App. 1963); 18 U.S.C. $\$ \$ 4244-8$ (1964). See generally Note, Civil Commitment of the Mentally Ill: Theories and Procedures, 79 HARv. L. REv. 1288 (1966); Comment, The Validity of the Segregation of the Sexual Psychopath Under the Law, 26 OHro Sr. L.J. 640,646 (1965).

359 See Note, Preventive Detention Before Trial, supra note 289, at 1504.

360 See Wiener, Helping to Cool the Long Hot Summers, 53 A.B.A.J. 713 (1967); Project, The Long, Hot Summer: A Legal View, 43 Notre DaMe Law. 918, 975-9 (1968).

361 The use of military detention and avoidance of the civil courts is advocated in a recent memorandum opinion by the Indiana Attorney General: "[D]etention of rioters in jail until the riot is suppressed is often considered more desirable than actual arrest which necessitates a turning over to civil authorities and setting of bond. The latter method would frustrate the attempt of the military to suppress since the person would rejoin the rioters upon being released on bail." 2 BNA CrIM. L. RPTR. 2376 (Feb. 14, 1968). 
that the most urgent task of the executive branch during civil disorder is to quell rioting, he nevertheless noted that

[T] he courts must protect the Constitutional right of the accused to reasonable bail. If both cannot be done, then the courts must not be forced to subvert due process by delaying or denying release on reasonable bail. Rather, the executive branch should declare martial law. ${ }^{302}$

It may be fruitful at the outset to review briefly the emergency powers granted to the governor and municipal officers of Illinois. ${ }^{363}$ The governor is authorized, as commander-in-chief, to mobilize the state's military forces to suppress violence. Whenever there is a riot or threat thereof,

it shall be deemed that a time of public disorder and danger then exists, and it shall be the duty of the Governor thereupon to order such military ... force as he may deem necessary to aid the civil authorities in suppressing such violence and executing the law. ${ }^{304}$

The commanding officer of the state military forces is then authorized to

arrest any person or persons in view without process and hold them in custody until, by order of the Commander-in-Chief, such person or persons are discharged from custody or delivered over to. the civil authorities. ${ }^{365}$

Under similarly broad constitutional and statutory authorization, state executive officers have invoked martial law on numerous occasions. Indeed, the best precedents for the use of preventive detention during conditions of civil disorder may be judicial decisions reviewing similar measures under situations of martial rule. ${ }^{366}$ Judicial review of

36252 J. AM. JUD. SOc'x 210-11 (1968).

303 ILL. Const. art. 5, § 14; ILI. REv. Stat. ch. 129, $\$ \S 220.83-.90$ (1967).

364 ILl. REv. STAT. ch. 129, § 220.83 (1967).

305 ILL. REv. STAT. ch. 129, § 220.84 (1967).

Subject to the authority of the governor, a mayor "may call out the militia to aid in suppressing riots and other disorderly conduct. . . ." ILL. REv. STAT. ch. 24, § 3-11-4 (1967). And the discretion of the military commander is broad: "Orders from civil officers to any military ... commander shall specify only the work to be done or result to be attained and shall not include the method to be employed as to which the military ... officer shall exercise his discretion and be the sole judge as to what means are necessary." Ill. REv. STAT. ch. 129, \& 220.85 (1967).

366 The decisions on martial law recognize the severity of the impact of military interference on basic constitutional guarantees. Ex parte Milligan, 71 U.S. (4 Wall.) 1, 123 (1866); Moyer v. Peabody, 148 F. 870, 876 (C.C. Colo. 1906). Since the impact is similar whether the military or police interfere, it would seem that the judicially evolved standards regulating military interference should also apply to police interference. 
executive and military measures taken pursuant to express or de facto declarations of martial rule has focused on two questions: (1) the conclusiveness of executive declarations of emergency; and (2) the measures which may be constitutionally taken to restore order. A review of instances of martial rule reveals that where a state of actual violence exists or is "immediate and impending" the courts have generally upheld the use of martial law. ${ }^{307}$ But where no state of violence is threatened, ${ }^{368}$ or where martial rule has been used for various political or economic reasons" ${ }^{369}$ - what one authority has called "bogus" martial rule ${ }^{370}$ - the courts have generally disallowed the governor's actions.

In considering the measures which may be constitutionally taken to restore order, it is useful to distinguish between situations in which military tribunals have been established to try offenders and instances of "qualified martial law" where the military is called to aid civil authorities. ${ }^{371}$ Although the use of military tribunals has been upheld in several instances, ${ }^{372}$ it has been sharply criticized, and it seems unlikely that such measures will be used again short of civil war. ${ }^{373}$

Almost all measures taken pursuant to a justified invocation of "qualified martial law" have been upheld, unless a measure was "arbitrary or capricious" or "bore no relation to the necessities of the

367 See, e.g., Moyer v. Peabody, 212 U.S. 78 (1909); Mitchell v. Harmony, 54 U.S. I15 (1851) ("the danger must be immediate and impending"); Cox v. McNutt, 12 F. Supp. 355 (S.D. Ind. 1935); In re Boyle, 6 Idaho 609, 57 P. 706 (1899); State ex rel. Roberts v. Swope, 38 N.M. 53, 28 P.2d 4 (1933).

368 See, e.g., United States ex rel. Palmer v. Adams, 26 F.2d 141 (D. Colo. 1928); Franks v. Smith, 142 Ky. 232, 134 S.W. 484 (1911); Bishop v. Vandercook, 228 Mich. 299, 200 N.W. 278 (1924).

369 See, e.g., Sterling v. Constantin, 287 U.S. 378 (1932) (regulate oil production); Allen v. Oklahoma City, 175 Okla. 421, 424-5, 52 P.2d 1054, 1058 (1935) (enforce racial segregation); Hearon v. Calus, 178 S.C. 381, 183 S.E. 13 (1935) (settle a political feud).

370 F. Wiener, A Practical manual of martial Law 102 (1940).

371 See, e.g., Commonwealth ex rel. WVadsworth v. Shortall, $206 \mathrm{~Pa}$. 165, 170, 55 A.2d 952, 954 (1963). See generally R. RANRIN, WhEN Civil Law FaIls chs. V, VII (1939). Some commentators have attempted to distinguish between "qualified martial law" and "military assistance." See, e.g., C. Fairaran, The Law of Martial Rule 30 (2d ed. 1943); R. RANKIN, supra at 146. Other Commentators have rejected the distinction as meaningless. See, e.g., WIENER, supra note 370, at 8; Ballantine, Military Dictatorship in California and West Virginia, 1 CalIF. L. REv. 413, 419 (1913).

372 United States ex rel. Seymour v. Fisscher, 280 F. 208 (D. Neb. 1922) (denying habeas corpus to petitioners convicted by military court for violating military regulation); United States ex rel. McMaster v. Wolters, 268 F. 69 (S.D. Texas 1920) (rejecting habeas corpus petition of defendant incarcerated pursuant to default of payment of fine levied on conviction for traffic violation in military court); Hatfield v. Graham, 73 W. Va. 739, 81 S.E. 533 (1914) (arrest on military warrant); State ex rel. Nance v. Brown, 71 W. Va. 519, 77 S.E. 243 (1912); Ex parte Jones, 71 W. Va. 570, 77 S.E. 1029 (1913).

373 See, e.g., In re McDonald, 49 Mont. 454, 476, 143 P. 947, 954 (1914); WIENER, supra note 370 , at 120 . 
situation."374 Detention has often been upheld as a valid incident of martial rule justifying a denial of the writ of habeas corpus. ${ }^{375}$ Hence, detention under martial law results in suspension by the executive of the privilege of the writ of habeas corpus-presumably justified by the nature of the emergency and subject to judicial review. ${ }^{376}$ Even if a petitioner is successful in obtaining a writ of habeas corpus, however, relief usually comes long after invasion of his rights. ${ }^{377}$

Martial law precedents vividly highlight the fact that the use of preventive detention is inherently punitive. Many courts have upheld the use of preventive detention as being a preventive rather than punitive measure, ${ }^{378}$ but it is difficult to sustain that distinction. The petitioner in Moyer $v$. Peabody, for example, was detained without hearing or adjudication for two and a half months by military authorities until the insurrection was over. ${ }^{379}$

In light of the broad discretion enjoyed by the executive and the military under conditions of martial rule, and the drastic effect of suspension of the privilege of the writ of habeas corpus, even "qualified martial law" should be entertained only as a means of absolute last resort. Nevertheless, martial rule has several advantages over the flexible guarantees rationale.

The principal advantage of the martial rule approach is that the

374 Powers Mercantile Co. v. Olson, 7 F. Supp. 865, 868 (D. Minn. 1934) (dictum); see Wilson and Co. v. Freeman, 179 F. Supp. 520 (D. Minn. 1959).

375 Moyer v. Peabody, 212 U.S. 78 (1909) (military detention); Cox v. McNutt, 12 F. Supp. 355 (S.D. Ind. 1935); In re Moyer, 35 Colo. 154, 85 P. 190 (1905) (military detention); In re Boyle, 6 Idaho 609, 57 P. 706 (1899); In re McDonald, 49 Mont. 454, 143 P. 947 (1914) (military detention); State ex rel. Roberts v. Swope, 38 N.M. 53, 28 P.2d 4 (1933). But see United States ex rel. Palmer v. Adams, 26 F.2d 141 (D. Colo. 1928) (no violence alleged); Franks v. Smith, I42 Ky. 232, 134 S.W. 484 (1911) (no evidence of violence). Contra, Ex parte Moore, 64 N.C. 802 (1870).

376 "[T] pre privilege or writ of habeas corpus shall not be suspended, unless when in cases of rebellion or invasion the public safety may require it." IrL. Const. art. 2, § 7. "The Privilege of the Writ of Habeas Corpus shall not be suspended, unless when in Cases of Rebellion or Invasion the public Safety may require it." U.S. CoNsT. art. 1, § 9, cl. 2.

377 See, e.g., In re McDonald, 49 Mont. 454, 143 P. 947 (1914) (writ granted almost a month after petitioner's arrest by military authorities); Moyer v. Peabody, 212 U.S. 78 (1909) (question reached the Supreme Court over four years after petitioner's release); In re Moyer, 35 Colo. 154, 85 P. 190 (1905) (question reached the state supreme court over a year after petitioner's release).

378 "Such arrests are not necessarily for punishment, but are by way of precaution to prevent the exercise of hostile power." Moyer v. Peabody, 212 U.S. 78, 84-85 (1909). But see Herlihy v. Donohue, 52 Mont. 601, 608, 161 P. 164, 166 (1916): “[W]e cannot concede to the organized militia, or to any department of our government, or to any function of government, the right to convict and punish without notice, a hearing or an adjudication."

379 In re Moyer, 35 Colo. 154, 85 P. 190 (1905). 
decisions which invoke restrictions on the rights of citizens are made by an officer directly responsible to the public. While both models postulate a determination of public danger as a requisite to abridgement of civil rights, the greater political responsiveness of the executive argues strongly for entrusting him with such critical decisions. The responsibility of the executive to an electorate makes it less likely that martial rule will be invoked in situations that pose only a minor danger to the populace. Furthermore, the costs of reliance on martial rule restrict its use: administrative and military costs are great, and the political costs of admitting that a breakdown of order has occurred may be substantial. Perhaps as a consequence of these factors resort to martial law has in recent times been relatively rare.

Another advantage of martial law is that the decision is a highly visible one; if it is imprudently made, criticism will be immediate. By contrast, a judicial finding of fact that an exceptional procedure is required by public necessity is easily made and subject to little publicity. The martial rule rationale, unlike the first approach, forces the community to face squarely the reality of the harsh measures taken. Unlike the first approach, a declaration of martial law publicly recognizes the suspension of constitutional guarantees, and lasts only as long as the emergency endures. ${ }^{380}$ The prospect of recurring invocations of martial law is, therefore, less likely and less objectionable than the prospect of diluted constitutional guarantees.

On the other hand, martial law has certain shortcomings not inherent in a flexible guarantees approach. Under martial rule executive authorities must choose between the unacceptable alternatives of inaction and suspension of the adjudicatory function of the criminal courts and the writ of habeas corpus. Although civil courts may remain open under situations of qualified martial rule, the military retains the capacity effectively to punish persons without an adjudication of guilt.

Thus neither the flexible guarantees model nor martial law precedents are acceptable rationales for the use of preventive detention during civil disorders. Assuming a legitimate public need for preventive detention under such circumstances, the criminal courts are in need of mechanism which avoids the risks of permanently dilut-

380 A military order, however unconstitutional, is not apt to last longer than the military emergency. ... But once a judicial opinion rationalizes such an order to show that it conforms to the Constitution, or rather rationalizes the Constitution to show that the Constitution sanctions such an order, the Court for all time has validated the principle ... [which] then lies about like a loaded weapon ready for the hand of any authority that can bring forward a plausible claim of an urgent need.

Korematsu v. United States, 323 U.S. 214, 246 (1944) (Jackson, J., dissenting). 
ing constitutional guarantees, on the one hand, and effectively preempting the judicial function on the other.

3. Limited Emergency Model. In response to the 1967 Detroit riots, two authors have proposed a limited preventive detention statute which combines the better features of the other two models. ${ }^{381}$ Like martial law, the proposed model is called into operation by executive declaration; this procedure avoids the risk of eroding constitutional guarantees by numerous exceptions. It outlines a more limited system of detention than martial law precedents sustain, and supplements rather than displaces the traditional bail institutions. Detained persons must be accorded an opportunity for release as soon as (1) the governor rescinds the declaration, or (2) the committing magistrate declares the emergency at an end, or (3) a judge declares the arrestees eligible for release on bail. ${ }^{382}$

If adhered to by bailsetting officers, the guidelines established under such a scheme ${ }^{383}$ might permit the early release of most arrestees, by avoiding detention of defendants charged with petty crimes or vague forms of misconduct. Only those whose release would create a substantial risk of reentry into the riot would be held. The authors estimate that perhaps $80 \%$ of riot arrestees could be immediately admitted to reasonable bail. ${ }^{384}$

If, as the authors of the Detroit study suggest, the breakdown of the bail system during riots is due to its failure to provide alternatives to pretrial release, ${ }^{385}$ their proposal, by providing such alternatives, should result in fewer unnecessary detentions.

The limited emergency model also avoids the major disadvantages of the earlier proposals. It recognizes that preventive detention may

381 Colista \& Domonkos, supra note 319, at 824-30.

382 The proposed statute would provide clear guidelines limiting the use of detention once an emergency has been declared. Provision is made for immediate and reasonable setting of bail in all cases, and for the suspension of bail only in those cases where there is "substantial evidence" that an arrestee (1) participated in inciting a riot, or (2) has a criminal record indicating violent or destructive anti-social behavior, or (3) committed or attempted to commit a serious crime against the physical safety of others, or arson, or violent destruction of property. $I d$. at 829 .

$383 \mathrm{Id}$. at $828-9$.

$384 \mathrm{Id}$. at 826 . The failure of the model to provide for counsel or review is presumably dictated by the need for rapid determinations. The presence of attorneys might prolong initial hearings so that many who would ultimately be released on bail would be detained through administrative processing. Similarly, review by a higher court would not only come too late to avoid such harsh consequences as loss of employment, but also, by requiring detailed written reasons for denying bail, would further prolong the initial hearing and delay the rapid release of most arrestees. Any safeguards written into preventive detention statutes operating during riots must be operative at the initial hearing stage rather than as subsequent remedies for judicial abuse of discretion.

385 Colista \& Domonkos, supra note 319 , at $826-8$. 
be justified in some situations, but it does not incorporate these emergency measures into constitutional doctrine. Furthermore, it employs the resources and experience of the criminal courts rather than entrust important adjudicative determinations to military officers. By steering a middle course between the dangers of a Constitution riddled with exceptions and military control, the limited emergency model reaches the most acceptable accommodation of individual rights and protection of the public interest.

\section{Conclusion}

There is an indication, however, that the pressure toward use of preventive detention during civil disorders is not, as the proponents of the limited emergency model assume, due to the failure of the bail system to provide alternatives to pretrial release. The third model establishes three criteria of future dangerousness. ${ }^{386}$ At least two of those criteria are also criteria in lllinois for setting bond: criminal record and the nature of the offense charged. Yet, as we have seen, many defendants with no prior criminal record and arrested on minor offenses were temporarily detained during the April 1968 riot. ${ }^{387}$ If magistrates were genuinely interested in detaining only those likely to reenter the riot, there were perhaps rational criteria, institutionalized into the bail system, with which to achieve that purpose.

The fact that in Chicago the absence of correlation between bond amounts and prior criminal record may be partly explained by the frequent unavailability of police prior arrest records illuminates an even more important reason why even the limited emergency proposal is likely to be unworkable in practice. One of the main reasons, as we noted, for the failure to hold individualized bail hearings is the great delay and administrative impracticality which such hearings entail. ${ }^{388}$ Those same factors are bound to thwart any attempt to individualize determinations of future dangerousness, even if accurate standards of prediction could be developed. More significant is the fact that magistrates, as we suggested earlier, are not prone to make individualized bail determinations under normal conditions. ${ }^{389}$ Nothing but wishful thinking supports the belief that they will do under conditions of civil disorder what they fail to do under ordinary circumstances. Indeed, all of the weaknesses of an overt preventive detention scheme under ordinary circumstances are retained and exaggerated under riot

386 See note 382 supra.

387 See Section IV supra.

388 See text at note 150 supra.

389 See text at notes 292, 293 supra. 
conditions. During those times when the pressure for an overt preventive detention system is greatest, its impracticality is most dramatic.

Of course, if the primary reason why magistrates fail to follow the requirements of bail statutes under either ordinary or riot conditions is their insistence on the need to detain arrestees for preventive purposes-that is, to prevent future crime or reentry into the riot-the impetus behind an express statutory scheme of preventive detention would be understandable. But, in fact, as we mentioned at the outset, there are at least two other reasons, in addition to the demand for administrative efficiency, which underlie the use of pretrial detention: punishment and general deterrence. Indeed, the main deficiency of proposed preventive detention plans is that they confuse one aspect of the problem-the most often articulated one-with the general problem. The use of pretrial detention is as much a result of the belief that it provides an appropriate sanction, especially for minor offenders, as it is a consequence of fears of risk to society which would result from the release of individual criminal defendants. In fact the incremental risk of individual defendants reentering a riot is probably minimal. The fact that the application of this sanction avoids formal criminal adjudication reflects two increasingly disturbing aspects of the criminal process, neither of them restricted to civil disorders. The central fact about any modern urban criminal justice system is the pressure of criminal caseloads. ${ }^{390}$ There is some indication that increasing caseload pressures are resulting in a larger number of pretrial dispositions. The percentage of felony cases reaching trial in Cook County, for example, declined from $22 \%$ to $17 \%$ between 1964 and $1967 .^{391}$ Recognition of the contemporary demand for efficiency in judicial administration has induced many writers to view the criminal system in terms of the competing goals of efficiency and due process. ${ }^{392}$

390 Between 1964 and 1967 the number of felony cases begun or reinstated in the Cook County Circuit Court increased 26\% (computed from AdMinistrative OfFice of THE ILLINoIs COURTS, 1967 ANNuAL COURT REPORT 60); the number of misdemeanor and ordinance violation cases terminated in the Municipal Department increased $18 \%$ (computed from 1967 ANNUAL CouRT REPORT 71 and 1964 ANNUAL COURT REPORT 82). In 1967 each judge and magistrate in the Cook County Circuit Court handles an average of 6,898 cases. 1967 Annual Court RePort 56. In the Cook County Criminal Courts the pressure for efficient disposition of criminal cases is dubbed the "disposition derby." With the approval of the chief.judge of the Criminal Court, a ranking is posted each month of the names of the judges and number of dispositions in each courtroom. Working Paper on Public Defender's Project, A Report to the Center for Studies in Criminal Justice, University of Chicago Law School 72 (1969) [hereinafter cited as Working Paper].

391 Calculated from data in 1967 Annual CourT Report 55, 1964 ANNuAL Court REPORT 62.

392 See, e.g., OAks \& LEHMAN 8 n.15; Barrett, Criminal Justice: The Problem of Mass Production, in American Assembly, The Courts, The Public, and The Law Explosion 
We shall explore the problems raised by these competing goals in the next section on the effectiveness of defense counsel. For our present purposes it is important to recognize that the goal of efficiency under conditions of increased caseload may result not only in a larger number of pretrial dispositions but also in an increased proportion of pretrial dismissals as the most efficient way to clear congested dockets.

Indeed, between 1964 and 1967 the guilty plea rate declined 8\% in felony cases in Cook County, and the proportion of cases dismissed before trial increased from $19 \%$ to $32 \%$ in felony cases and increased $8 \%$ in misdemeanor and ordinance violation cases. ${ }^{393}$ Although the increasing incidence of early dismissals may be due in part to the greater availability of defense counsel, recent Illinois bail reform, and other factors, it would seem in large part to reflect pressures toward economy in the criminal courts.

But there is a second aspect of the modern criminal process equally as significant as the pressure toward judicial economy-the loss of the presumption of innocence. "The spirit in 'the building'," one Cook County Public Defender has written of the Chicago criminal courts "runs counter to the belief that 'all men are innocent until proven guilty'." 394 Many Cook County public defenders estimate that $95 \%$ of their clients are guilty. ${ }^{395}$

In light of the presumption of guilt and need for efficiency which characterize the contemporary criminal process, the immediate goal of a modern criminal system can be stated as the efficient application of appropriate sanctions consistent with procedural due process. The ultimate goal of the criminal process is presumably the general deterrence of criminal behavior.

Given demands for efficient judicial administration and the pre-

(1965); H. Subin, Cruminal Justice in a Metropoltan Court (1966). Sociologists, too, have recently conceptualized the criminal system as a bureaucratic organization whose determinations can be viewed in relation to the bureaucratic and organizational pres. sures which threaten efficient performance. Thus, Jerome Skolnick in reference to the police, and Abraham Blumberg in reference to the handling of felony cases, have suggested that pressures encouraging efficiency, mass production, and the clearing of police and court dockets are instrumental in explaining the determinations of officers of the criminal system. J. Skolnick, Justice Without Trial (1966); A. Blumberg, Criminal Justice (1967); see also Sudnow, Normal Crimes: Sociological Features of the Penal Code in a Public Defender Office, 12, Soc. PROBs. 255 (1965).

393 Computed from 1967 Annuar Court Report 55, 71, and 1964 ANnuar Court REPORT 62, 82.

394 Working Paper 72.

"The 'adversary system' and the 'presumption of innocence' are compromised in the framework of the formal court process itself. They are supplanted by a non-adversary, accusatory system which actually favors a presumption of guilt." BLUMBERG, supra note 392 , at 6 .

305 Working Paper 70. The estimate refers to indicted defendants in the Criminal Division, rather than defendants in the Municipal Department. 
vailing presumption of guilt, the significance of pretrial detention under ordinary circumstances becomes clear. Giving presumably guilty arrestees a "taste of jail" is an effective sanction which avoids the necessity of formal adjudication.

The use of pretrial detention under conditions of civil disorder is, to some degree, merely a manifestation of normal pressures on the court system. The pressure toward judicial economy, for example, is aggravated by large numbers of mass arrests which may ultimately result in low conviction rates among riot arrestees. ${ }^{396}$ The apparent conflict between the presumption of guilt and expected low conviction rates is reconciled in the use of pretrial detention.

But the use of pretrial detention in mass arrest situations also burdens inadequate detention facilities and crowded bail court dockets. To some extent, then, pretrial detention is clearly a calculated inefficiency which courts tolerate because it permits attainment of other goals. This fact highlights the importance during civil disorders of pretrial detention as a form of punishment and general deterrence. Judging by the remarks of court officials themselves, it is apparent that the use of pretrial detention during riots reflects not so much an intent to prevent individual arrestees from reentering the riot as a desire either to punish arrestees or deter potential rioters. ${ }^{397}$

In terms of the traditional goal of general deterrence, riots present a unique problem to any criminal justice system. The prospect of formal adjudication and conviction may be thought to be far too remote to provide any immediate deterrent effect. In light of estimates that the number of actual rioters in recent disorders is five times the number arrested, ${ }^{398}$ the criminal courts may be inclined to opt for

396 Kerner Commission Report 184. In Chicago the criminal system avoided low conviction rates by carefully screening arrests, and by careful attention to the nature of charges levied against riot arrestees.

397 See text at notes 325-30 supra. Those remarks suggest that the courts exercised broad discretion in detaining large numbers of people, regardless of their guilt or innocence. In justifying this extreme practice, it might be argued that such mass detention is the only effective means of quelling disorders, not only because it serves as a deterrent to potential rioters, but also because innocent bystanders might be thought of as providing an indispensable "audience" whose mere presence in the area provides both encouragement and a protective shield to active rioters. Standards narrowly delineating only the most dangerous conduct as warranting detention would then be considered undesirable, because it is the widespread audience for and participation in property offenses during riots which the courts hope to deter. The looter and bystander may pose as great a threat to quelling a riot as the arsonist, even though the "criminality" of his conduct might not be such as would ordinarily justify the harsh deprivation which detention involves.

398 Fogelson \& Hill, Who Riots? A Study of Participation in the 1967 Riots, SurpleaIENTAL, Studies for the NAtional Advisory Commission on Civil Disorders 230-1 (1968). 
pretrial detention as a telescoped deterrent response, in order to achieve an immediate impact.

Whether in fact temporary detention is an effective measure of general deterrence is, of course, open to question. ${ }^{399} \mathrm{It}$ is important to remember that in Chicago at least the bulk of arrests occurred during and after peak riot periods. In many instances the real purpose of so-called preventive detention may be informal retribution-"a slap on the wrist." In any case, the real issue posed by pretrial detention during riots is not preventive detention but the informal application of pretrial sanctions.

Within our constitutional framework the application of pretrial sanctions clearly raises serious objections. Those objections are particularly real during civil disorders, for regardless whether the presumption of guilt is in fact accurate under ordinary circumstances, there is grave doubt that mass arrest decisions under riot conditions are as reliable an indication of guilt. Furthermore, as we noted earlier, the Gook County criminal courts granted automatic continuances in most misdemeanor cases and avoided probable cause hearing in most felony cases. In many instances convicted defendants were fined or sentenced only to the equivalent of time already served in pretrial detention. The effect of those policies, coupled with use of pretrial detention, is, as one arrestee put it, that the police "can conduct their court right out there on the street and define the guilty." Or, as another arrestee remarked, "The police are to bring them in, and the courts are to lock 'em up."

Of course it may be true, as one commentator has said, that "the observance of suspects' and defendants' rights is not good politics." 400 There was in Chicago during the April riots much concern that rioters be punished. ${ }^{401}$ But the task should properly follow, rather than render meaningless, an adjudication of guilt.

399 There is some indication that temporary detention did not have a deterrent effect on the arrestees themselves. The following responses to an interviewer's question whether the respondent would take part in another riot were typical:

This would make me look back and say $I$ wish that I did something because if I'm going to go to jail and haven't did anything, I gonna say I wish I had did something.

Well, I probably would take part in the riot because most likely, if all the blacks get together and know what they are going to do and why they are doing it, there won't actually be a riot, there would be somewhat of a revolution.

400 Kamisar, Book Review, 78 Harv. L. Rev. 478, 487 (1964); see also R. JAckson, The SUPREME COURT 82 (1955).

401 See, e.g., Punishment for the Rioters, Chicago Tribune, April 11, 1968, § 1, at 20. 


\section{The Right to Effective Counsel}

In earlier sections of this study we have referred to the role of defense counsel during the April disorders in Chicago. In this section we examine the effectiveness of legal representation accorded riot defendants in light of the present posture of the law regarding a criminal defendant's right to effective representation. In conclusion we offer some observations on the role of the Public Defender in the criminal process.

\section{A. The Right to Counsel}

Consideration of the right to effective counsel must necessarily begin with a more basic right-the right to have counsel appointed at all. In Gideon v. Wainright, ${ }^{402}$ the Supreme Court established an indigent's right to appointed counsel during the trial in felony cases. ${ }^{403}$ The Court, however, left two questions unresolved: (1) Does the right extend to misdemeanors and, if so, to which cases? ${ }^{404}$ (2) At what stages during the criminal process is the right applicable?

Despite continuing uncertainty over the right to appointed counsel in misdemeanor cases, ${ }^{405}$ it is likely that the Supreme Court will eventually extend the right of all indigent defendants except those charged with "petty" offenses, by analogy perhaps to the sixth amendment right to jury trial. In Duncan v. Louisiana, ${ }^{408}$ the Court held that the sixth amendment right to jury trial "in all criminal prosecu-

\footnotetext{
402372 U.S. 335 (1963).

403 Justice Clark in his concurring opinion stated that the decision erased the meaningless distinction between capital and non-capital offenses, saying that: "The Fourteenth Amendment requires due process of law for the deprival of 'liberty' just as for the deprival of 'life,' and there cannot constitutionally be a difference in the quality of the process based merely upon a supposed difference in the sanction involved." 372 U.S. at 349 .

404 Justice Harlan's concurring opinion suggested that the rule might well be restricted to felonies involving a "substantial" prison sentence and cautioned that "[w] hether the rule should extend to all criminal cases need not now be decided." 372 U.S. at 351.

405 See Winters v. Beck, 239 Ark. 1151, 397 S.W.2d 364, cert. denied, 385 U.S. 907 (1966). The Arkansas Supreme Court had denied habeas corpus to a defendant convicted of the misdemeanor of "immorality," holding that the rule of Gideon does not apply in misdemeanor cases. But see McDonald v. Moore, 353 F.2d 106 (5th Cir. 1965), and Harvey v. Mississippi, 340 F.2d 263 (5th Cir. 1965), each holding that Gideon assures a right to counsel to an indigent defendant charged with the misdemeanor of "possession of whiskey."

406391 U.S. 145 (1968).
} 
tions" extends to all but "petty crimes." 407 It seems reasonable to assume that the sixth amendment right to assistance of counsel "in all criminal prosecutions" is coextensive with the jury trial right. In Cook County the question is apparently resolved by the Illinois Criminal Code which provides that "the Public Defender shall be appointed as counsel in all misdemeanor cases where the defendant is indigent and desires counsel . . . ."408

Recent Supreme Court decisions have considered whether the right to counsel is applicable in pretrial criminal proceedings. In Hamilton $v$. Alabama, ${ }^{409}$ the Court reversed the defendant's conviction because he had been denied appointment of counsel at his arraignment. The Court held that the arraignment was a "critical stage" in the criminal prosecution, noting that under Alabama law certain defenses could not be raised at trial if they were not pleaded at the arraignment. ${ }^{410}$

The "critical stage" rationale of Hamilton was apparently followed in White v. Maryland. ${ }^{411}$ The Supreme Court found a violation of the due process clause when White pleaded guilty without the assistance of counsel at his preliminary hearing. The defendant later changed his plea to not guilty, but his original guilty plea was introduced in - evidence against him at trial. In Pointer $v$. Texas, ${ }^{412}$ however, the Court in dictum rejected the petitioners argument that the state had violated the fourteenth amendment by failing to provide him counsel at his preliminary hearing, since guilty pleas are not accepted at a Texas preliminary hearing. At such hearings "the judge decides only whether the accused should be bound over to the grand jury and if so whether he should be admitted to bail." 413

The Illinois Supreme Court, in People $v$. Morris, ${ }^{414}$ reached a conclusion similar to the Pointer dictum. ${ }^{415}$ The court emphasized that

407 Defendant was convicted of the misdemeanor of "simple battery," punishable by two years in prison and a $\$ 300$ fine. His actual sentence was 60 days and $\$ 150$ fine. See also Bloom v. Illinois, 391 U.S. 194 (1968).

408 ILL. REv. STAT. ch. 38, § 113-3(b) (1967). It should be noted, however, that if the case involves multiple defendants the "court may appoint counsel other than the Public Defender for the additional defendants." Id.

409368 U.S. 52 (1961).

410 Among those defenses which would be "irretrievably lost" if not pleaded at the arraignment were the defense of insanity, pleas in abatement, motions to quash based on racial exclusion in the grand jury, and motions to quash for improper drawing of the grand jury. 368 U.S. at 53-54.

411373 U.S. 59 (1963).

412380 U.S. 400 (1965).

$413 \mathrm{Id}$. at 402 .

41430 III. 2d 406, 197 N.E.2d 433 (1964).

416 The Illinois court's discussion of the right to counsel issue was also dictum since the decision to grant a new trial was based on the failure to allow cross-examination of the complaining witness as to his sobriety. 
the absence of counsel at a preliminary hearing in Illinois can in no way prejudice the defendant's subsequent trial. ${ }^{416}$

The "critical stage" cases could be read to mean that the sixth amendment right to counsel matures at a particular point in time prior to trial, normally at a "stage" in the proceedings at which the defendant may enter a plea. According to such an analysis, whether a denial of counsel violates the due process clause would depend on whether the denial took place during or after the "critical stage." But Miranda $v$. Arizona $a^{417}$ casts doubt upon this approach. In Miranda the Court held that all suspects in custody have a right to counsel prior to any police interrogation. It would appear, then, that station house interrogations are a "critical stage" in the criminal process, even though they may precede the preliminary hearing in such states as Illinois or Texas.

Miranda can be squared with the critical stage cases, however, if "critical stage" is defined as any proceeding which can directly affect, in some significant manner, the conduct of the defense at trial or the formal disposition of the case. ${ }^{418}$ Thus it seems that the courts consider the right to counsel in pretrial stages essential only when a proceeding bears upon the ultimate determination of guilt or innocence. According to this approach, a bail hearing is not "critical," even if it results in prolonged confinement in a dirty, overcrowded jail and loss of employment or wages. In focusing primarily on the rights of the accused which are related to the formal disposition of his case, this narrow reading of the "critical stage" approach thus ignores major incidents of impact of the criminal justice system upon the individual, which may be far more important to him than the determination of his guilt or innocence.

\section{B. The Right to Effective Counsel}

A constitutional or statutory right to appointed counsel is meaningless if it does not imply a right to competent representation. Both

416 The Morris decision predates enactment of $\S 109-1(b)(2)$ of the Illinois Code of Criminal Procedure, which provides that a person arrested without a warrant shall be taken without unnecessary delay before the nearest and most accessible judge. The judge shall, inter alia, "advise the defendant of his right to counsel and if indigent shall appoint a public defender or licensed attorney at law of this State to represent him in accordance with the provisions of Section 113-3 of this Code." ILr. REv. STAt. ch. 38, $\$ 109$ 1(b) (1967). Although this provision might have cast some doubt on the continuing validity of the Morris holding, the Illinois Supreme Court has held that $\$ 109-1$ does not create a statutory right to counsel at the preliminary hearing. People v. Bonner, 37 Ill. 2d 553, 229 N.E.2d 527 (1967).

417384 U.S. 436 (1966).

418 See, e.g., DeToro v. Pepersack, 332 F.2d 341 (4th Cir. 1964), in which the Fourth Circuit Court of Appeals spoke of "prejudice to defendant's ensuing trial." See also Hamilton v. Alabama, 368 U.S. 52 (1961); People v. Rebenstorf, 37 Ill. 2d 572, 229 N.E.2d 483 (1967); People v. Bonner, 37 Ill. 2d 553, 229 N.E.2d 527 (1967). 
federal and Illinois courts appear to recognize a right to effective representation, based on the sixth amendment right to assistance of counsel ${ }^{419}$ at many stages of the criminal process. ${ }^{420}$ But the legal standards governing the effectiveness of counsel, and remedies available to the defendant denied effective representation, are presently unclear. Illinois courts have reversed convictions for lack of effective representation where counsel failed to object to the introduction of selfincriminating evidence, ${ }^{421}$ to move for a mistrial when the jury heard evidence that the victim was pregnant when killed, ${ }^{422}$ and to move for dismissal for lack of speedy trial. ${ }^{423}$

The Illinois cases generally indicate that in order to obtain a reversal a defendant must prove (1) actual incompetency and (2) "substantial prejudice resulting therefrom, without which the outcome would probably have been different." 424 Appellate courts thus treat

410 In People v. DeSimone, for example, the lllinois Supreme Court ordered a new trial, stating, "A defendant's right to assistance by counsel is not satisfied by the mere formality of an appointment of an attorney by the court, but . . embraces effective representation throughout all stages of the trial, and where the representation is of such low caliber as to amount to no representation ... the guarantees of due process are violated." 9 Ill. $2 d$ 522, 524, 138 N.E.2d 556, 557 (1956).

420 See, e.g., Entsminger v. Iowa, 386 U.S. 748 (1967) (failure to prosecute appeal); Anders v. California, 386 U.S. 738 (1967) (failure to prosecute appeal); Powell v. Alabama, 287 U.S. 45 (1932) (no counsel appointed until morning of trial); United States ex rel. DeMary v. Pate, 277 F. Supp. 48 (N.D. Ill. 1967) (failure to consult defendant before and during trial). Illinois cases are cited infra notes $421-4$. Even if there be no constitutional right to appointed counsel at the early stages of the criminal proceedings, Illinois provides this right by statute-at least at the pleading stage. Int. REv. STAT. ch. 38, § 113-3(a) (1967), and this should be a sufficient basis for the right to effective counsel.

421 People v. DeSimone, 9 I11. 2d 522, 138 N.E.2d 556 (1956); People v. Odom, 71 III. App. 2d 480, 218 N.E.2d 116 (5th Dist. 1966).

422 People v. McCoy, 80 Ill. App. 2d 257, 225 N.E.2d 123 (1st Dist. 1967).

423 People v. Morris, 3 IIl. 2d 437, 121 N.E.2d 810 (1954).

424 People v. Morris, 3 Ill. 2d 437, 449, 121 N.E.2d 810, 817 (1954). See also People v. DeMary, 37 Ill. 2d 364, 227 N.E.2d 361 (1967); People v. Williams, 36 IIl. 2d 194, 222 N.E.2d 321 (1966), cert. denied, 388 U.S. 923 (1967); People v. Ashley, 34 Ill. 2d 402, 216 N.E.2d 126 (1966); People v. DeSimone, 9 Ill. 2d 552, 138 N.E.2d 556 (1956).

The Illinois courts have thus declined to follow the approach in Hamilton where the Court said: "[W]e do not stop to determine whether prejudice resulted [when the defendant pleaded without counsel in a capital felony case]. . . . [T] he degree of prejudice can never be known." 368 U.S. at 55. This might be termed the "prejudice per se" approach, where the defendant is granted a reversal merely upon showing that his constitutional right was infringed, without a showing of actual prejudice. Putting the burden of proof on the defendant to show actual prejudice is questionable because (1) actual prejudice may be absent from the record precisely because counsel was ineffective, (2) as the Supreme Court has indicated in adopting a prophylactic rule in the context of incustody interrogation, requiring courts to examine the record for actual prejudice burdens judicial administration and inevitably raises difficult and unavoidable factual assessments, and (3) the burden of proof is and should be on the state in criminal proceedings. See Chapman v. California, 386 U.S. 18 (1967), where the Court held that 
the due process requirements of the right to counsel and the right to effective representation similarly; both issues are related only to the ultimate determination of guilt or innocence in an adversary setting and not to the prejudicial effect of the criminal process on the defendant's interests in general.

The "substantial prejudice" rule-that incompetency per se will not require reversal ${ }^{425}$-markedly restricts the legal remedies available to a criminal defendant who is denied effective representation. It is often difficult to prove the existence of actual prejudice. ${ }^{426}$ The inadequacies of remedies for ineffective counsel are particularly acute with respect to the bail hearing, as we shall see, where as a result of competing goals of efficiency and due process the ineffectiveness of counsel is most significant. If the result of counsel's ineffectiveness is a high bond determination resulting in prolonged pretrial detention, the defendant is virtually without a remedy. ${ }^{427}$

In examining the effectiveness of counsel during the April riots, we shall consider primarily how ineffective representation influenced the impact of the criminal process upon the defendant. And since the focus of the study has been on all. of the sanctions imposed by the criminal system during each stage of the criminal process rather than on the ultimate determination of guilt or innocence, our inquiry into the effectiveness of counsel must be broader than the representation by counsel at trial.

the state must show that constitutional error (infringement on fifth amendment rights) was harmless beyond a reasonable doubt.

425 It is also true in Illinois that a showing of actual prejudice is not sufficient for reversal. See People v. Kuczynski, 33 III. 2d 412, 211 N.E.2d 687 (1965), where the court held that despite obvious prejudice, counsel's mistake was one that any competent counsel could have made.

426 In People v. Ashley, 34 Ill. 2d 402, 216 N.E.2d 126 (1966), when appellant failed to show in what specific ways counsel had been incompetent, the Illinois Supreme Court suggested that appellant could have tried to prove the existence of evidence not introduced by the Public Defender. See generally note 424 supra.

427 We have already noted in the section on preventive detention that there is little or no effective relief based on the unreasonableness of bail determinations. See text at notes 303-10 supra. As we have noted in the present section, the defendant is also unlikely to succeed in obtaining relief if he bases his claim on denial of right to effective counsel at the bail hearing because under the traditional "critical stage" approach the severity of impact on the defendant of high bail is not directly related to an adverse formal disposition of the case and hence is beyond the pale of judicial protection. And even if a defendant is successful in urging a court to consider the critical personal impact of a high bail determination, unless he can also demonstrate actual substantial prejudice to the formal disposition of his case, he is still without an effective appellate remedy unless a reviewing court is willing to reverse the conviction solely in order to protect defendants against adverse impact of denial of effective counsel at pretrial stages. 


\section{The Representation of Riot Defendants}

Virtually all riot defendants were represented by the Public Defender's office at initial bail hearings. ${ }^{428}$ Private counsel, however, represented many riot defendants during later stages of the criminal proceedings. ${ }^{420}$ The Public Defender did not formally withdraw from such cases, but "stood aside" to permit private attorneys to assume the defense. ${ }^{430}$ We shall first examine the role of counsel at the bail hearings; then we shall compare the effectiveness of the Public Defender and private attorneys in relation to the formal disposition of the riot cases.

1. Bail Hearings. Data compiled from a sample of 202 adult bail hearings transcripts reveal that counsel was in fact present in all but $7 \%$ of the cases. (See Table 50.) Private attorneys represented $4 \%$

TABLE 50

Type of Counsel at BaIl Hearing

\begin{tabular}{cc}
\hline & $\%$ \\
$\begin{array}{l}\text { Public Defender Appearance } \\
\text { Public Defender Participating, } \\
\text { but no Appearance }\end{array}$ & 79 \\
Private Attorney Participating & 10 \\
Public Defender Appearance and & 3 \\
Private Attorney Participating & \\
No Defense Counsel & 1 \\
Total & 7 \\
Number & $100 \%$ \\
\hline
\end{tabular}

of the defendants, and the Public Defender represented the remaining $89 \%$.

The small number of private counsel present at bail hearings is attributable to several factors. Private attorneys were not authorized to file limited appearances and were reluctant to undertake the criminial defense in many cases. ${ }^{431}$ Moreover, the Public Defender

428 Telephone interview with Thomas Cawley, First Assistant Public Defender, Cook County, Nov. 28, 1968.

429 See Table 51.

430 Our data indicate that only one written defense motion for leave for the Public Defender to withdraw was made, and that motion was granted by the court.

431 By April 12, private attorneys, over the objection of the Public Defender, were allowed to file limited appearances which enabled them to represent defendants at the bond reduction hearings without undertaking to represent the defendants generally. Austin CoMmrtee Report 90; Platt Report 14. 
and State's Attorney repeatedly stated during the early riot period that the Public Defender would be able to handle all arrestees and that there was no need for volunteer lawyers. ${ }^{432}$ Many volunteers were not allowed to take cases, according to judicial authorities, ${ }^{433}$ because they were either law students or not admitted to practice in Illinois. Volunteer attorneys were also turned away for alleged security reasons, because of the fear of sabotage to the central communications network of the police department, a few floors below the courtroom. ${ }^{434}$ Both the court rule barring lawyers not specifically requested by criminal defendants ${ }^{435}$ and a statutory rule precluding the appointment of private counsel in misdemeanor cases in Cook County, ${ }^{430}$ restricted the number of private attorneys at the bail hearings. During the early riot period defendants were generally not allowed counsel of their choice. ${ }^{437}$ Although the situation changed somewhat over the weekend there is evidence that even on Sunday defendants were not freely allowed to choose private counsel. ${ }^{438}$ As one commentator concluded, "[private] attorneys were clearly not welcome in the proceedings." 439

After Sunday, when private volunteers were permitted to assist

\footnotetext{
432 Austin Committee Report 99; Platt Report 9, 13.

433 Austin CoMmittee Report 86.

434 Id. As one Cook County Bar Association lawyer, who was turned away from the central police station at which bail hearings were being held, reported:

There were policemen at the door demanding credentials before they would allow anyone to come in. A young policeman stopped me and asked me where I was going. I gave him one of my cards identifying me as a lawyer. . . . So another young policeman stepped up and said "What is your business here?" I said I told you before that $I$ am a lawyer and there is a court hearing going on in there and my license says that $I$ am a member of that court and $I$ want to go in now. I was not in the mood to be kicked around .... and I told him to go in and get somebody that he could take directions from to find out whether he really had the authority to keep me out of the building. At that point he said, "Well, go on in." Platt Report 5.
}

435 See Austin Commite Report 86.

436 ILl. REv. STAT. ch. 38, § 113(3)(b) (1967).

437 Ginsberg Testimony 190; Platt Report 5. It was not always in the defendant's interest to choose his own attorney even when so permitted as the following bail hearing transcript reveals:

The Court: Do you want the Public Defender here to defend you, or are you going to get your own attorney?

The Defendant: I want my own attorney.

The Court: Allright. I will ask you [a Public Defender] to sit down. You don't defend him. What does the State recommend?

The State's Attorney: $\$ 3000.00$.

The Court: \$3000.00 bond, Branch 47, April 15, 1968.

438 Remarks of a private defense attorney at a meeting of the Cook County Bar Association, April 16, 1968.

439 Platt Report 6; as the Austin Committee said: "The initial reaction of the magistrates and the public defender to the volunteers seems to have been one of discouraging their appearance on behalf of arrestees in the bond hearings." Austin CoMmitTEE REPORT 90. 
the Public Defender, they helped to obtain information from the arrestees relevant to the setting of bond. ${ }^{440}$ In light of the general disregard of individual circumstances in setting bail discussed in Section IV above, the significance of this volunteer assistance should not be exaggerated. Legal Aid Lawyers also undertook the clerical duties of bond clerks, however, and assisted relatives to locate arrestees and arrestees to contact relatives. As one observer has written: "The volunteer lawyers and law students saved the bail system from complete chaos by helping at this stage." 441

Despite the Illinois statutory provisions permitting an arrestee to communicate with an attorney and a member of his family, ${ }^{442}$ lawyers and even Public Defenders were prohibited during the early riot period from interviewing defendants in the bullpens before their bail hearings and, on occasion, from interviewing defendants at the County Jail; defendants were often unable to make phone calls. ${ }^{443}$

TABLE 51

Type of Counsel at Various Stages of Court Proceedings

\begin{tabular}{lccc}
\hline & $\begin{array}{c}\text { Per Cent } \\
\text { Court Appearance }\end{array}$ & $\begin{array}{c}\text { Total } \\
\text { Private Attorneya }\end{array}$ & $\begin{array}{c}\text { Public Defender } \\
\text { Number of } \\
\text { Hearings } \\
\text { of this type } \\
(=100 \%)\end{array}$ \\
\hline $\begin{array}{l}\text { Bail Hearing } \\
\text { (First Court Appearance) }\end{array}$ & 1 & 99 & $(1964)$ \\
$\begin{array}{l}\text { First Bond } \\
\text { Reduction Hearing }\end{array}$ & 8 & 92 & $(472)$ \\
$\begin{array}{l}\text { Second Bond } \\
\text { Reduction Hearing }\end{array}$ & 9 & 91 & $(74)$ \\
$\begin{array}{l}\text { Second Court } \\
\text { Appearance }\end{array}$ & 13 & 87 & $(2136)$ \\
Final Court \\
Appearanceb
\end{tabular}

a This column includes only those private attorneys who filed appearances.

b This data refers to the final court appearance in Municipal Court. It is probable that a greater proportion of defendants against whom indictments were obtained, resulting in their transfer to the Criminal Court, had private representation in Criminal Court.

In summary, the Public Defender assumed the representation of almost all of the defendants at bail hearings-even the non-indigentand also represented the great majority of defendants at later stages

440 Platt Report 6; Austin Commitree Report 90; Ginsberg Testimony 192-3.

441 Platt Report 17; see Austin Commirte Report 86, 90.

442 Inc. REv. STAT. ch. 38, §§ 103-3, 103-4 (1967).

443 Platt Report 7-8; Ginsberg Testimony 190. 
- TABLE 52

Type of Counsel by Seriousness of Chargea

\begin{tabular}{lccr}
\hline \multicolumn{1}{c}{ Charge } & $\begin{array}{c}\text { Per Cent } \\
\text { Private Attorney }\end{array}$ & $\begin{array}{c}\text { Per Cent } \\
\text { Public Defender }\end{array}$ & $\begin{array}{r}\text { Number } \\
\text { of Cases } \\
(=100 \%)\end{array}$ \\
\hline Curfew & 1 & 99 & $(575)$ \\
Disorderly Conduct & 5 & 95 & $(448)$ \\
Resisting Arrest & 18 & 82 & $(33)$ \\
Misdemeanors, Personal & 17 & 83 & $(12)$ \\
Misdemeanors, Property & 23 & 77 & $(136)$ \\
Feloniesb & 27 & 73 & $(698)$ \\
Two or more Chargesb & & & $(213)$ \\
& & & $(2115)$
\end{tabular}

a The seriousness of the crimes charged was determined by ranking the charges according to the average amount of bail set for defendants charged with that crime.

b These categories are not examined in more detail because our data is only complete through the last appearance in Municipal Court, and it is probable that many of those charged with felonies who were not represented by private counsel in the Municipal Court retained private counsel before disposition of their cases.

in the criminal proceedings, particularly those with less serious charges. ${ }^{444}$ (See Tables 51 and 52.) But the mere presence of the Public Defender by no means assured effective representation for defendants. On the contrary, at many bail hearings the Public Defender was not responsive to the defendant's interests.

Analysis of our sample of 202 adult bond hearing transcripts reveals that the Public Defender made specific bond requests in only $15 \%$ of the cases and that in only $8 \%$ did the court's bond determination reflect the influence of the Public Defender's recommendation. The State's Attorney, however, made recommendations in $69 \%$ of the cases, and his suggestion was accepted by the court in $43 \%$.

When the Public Defender took the initiative in questioning the defendant, the amount of bond set by the court was less than that recommended by the State's Attorney in nearly half the cases in which the State's Attorney made a bond recommendation. When the Public Defender failed to question the defendant, with the usual result that the court itself undertook the questioning, the amount set by the court was less than that recommended by the State's Attorney in only $23 \%$ of the cases. Bond, then, was set at lower amounts when the Public Defender questioned the defendant. Yet the Public Defender led the questioning in only $42 \%$ of the cases. In $37 \%$ the

\footnotetext{
444 Although Illinois law only requires appointment of the Public Defender in misdemeanor cases when the defendant is indigent, the Public Defender undertook to represent most defendants regardless of indigence. See IrL. REv. STAT. ch. 38, § 113-3(b) (1967).
} 
magistrate conducted most of the interrogation, and in $21 \%$ the defendant was asked few, if any, questions. ${ }^{45}$

The failure of the Public Defender to examine his clients in more than half the cases is particularly egregious in light of the clear purpose of the bail hearing. Section 110-2 of the Illinois Code of Criminal Procedure provides for release on recognizance "[w]hen from all the circumstances the court is of the opinion that the accused will appear as required." 446 And Section 110-5 provides in part that the amount of bail shall be "[c]onsiderate of the past criminal acts and conduct [and] . . . the financial ability of the accused." 447

Even in those instances in which the Public Defender did question a defendant, he often elicited responses unfavorable to his client for the purposes of setting bail, revealing his lack of preparation. Twentynine per cent of the defendants who were asked by the Public Defender if they had prior arrest records answered affirmatively. Although only five of the 41 defendants who were asked how long they had resided in Chicago had lived in Chicago for less than three years, that information was elicited from four of the five defendants by the Public Defender. Forty-five per cent of the defendants questioned as to their marital status were unmarried, yet in more than $50 \%$ of those instances in which a Public Defender elicited marital status information, the defendant was unmarried. And the same pattern emerges from analysis of questions regarding family status. In short, it is clear that the Public Defender made no inquiry into the individual circumstances of his clients before asking them questions which may have adversely affected their bail determinations. ${ }^{448}$ This finding supports the conclusion of the Mayor's Riot Study Committee that:

... the public defenders did not have or take the time to interview or question the arrestees respecting ['the essential factors necessary for setting bonds'] prior to their bond hearing appearances before the magistrate . . . .449

445 In one instance a Public Defender who had filed an appearance on behalf of 27 defendants failed to speak once while each of the 27 paraded before the bond magistrate to have bail set. The failure of the Public Defenders to take the initiative in the questioning, however, may in part reflect deference to the known styles of particular magistrates.

446 ILI. REV. STAT. ch. 38, § 110-2 (1967).

447 Irr. Rev. Stat. ch. 38, § $110-5$ (1967).

448 Cf. United States ex rel. DeMary v. Pate, 277 F. Supp. 48 (N.D. III. 1967) in which defendant's conviction was reversed on a finding of inadequate representation before and during trial; counsel's examination of defendant at trial had elicited testimony which prior consultation would have revealed was adverse.

449 AUSTIN COMMITTEe Report 89. 
Another indication of the ineffectiveness of the Public Defender at the bail hearings is that despite his presence at almost all of the hearings, two-thirds of the small sample of defendants whom we interviewed at length stated that they were not represented by counsel at this stage of the proceedings.

It is apparent from our earlier discussion in Section IV that in terms of the impact of the criminal process upon the individual defendant, ability or inability to secure adequate representation at the earliest stage of this process is often vital. ${ }^{450}$ For example, one defendant represented by the Public Defender was charged with burglary and bond was set at $\$ 5,000$. After a month of incarceration his bond was reduced to $\$ 1,000$, enabling his father to post bail. But as a result of pretrial detention the defendant lost his job in a local restaurant and was unable to secure employment for five months. If the time at which a defendant's right to counsel matures is viewed in light of his personal stake in the proceedings, the bond hearing or preliminary hearing must be a "critical stage." But even if "critical stage" is defined in terms of the effect of the pretrial proceedings on the ultimate disposition of the case, ${ }^{451}$ our data suggest that the right to counsel was constitutionally required in many of the preliminary hearings we reviewed. Despite contrary statutory provisions, in 55 of the 202 sample bond hearing transcripts, or $27 \%$ of the cases, defendants were required to enter a plea to the charges against them. ${ }^{452}$

But the riot defendants may have had an enforceable right to effective representation at their bail hearings even in the absence of a constitutional or statutory right to counsel at that stage. As we noted, volunteer counsel were excluded from the hearings largely

\footnotetext{
450 At least one court has recognized this. In reversing a narcotics conviction for absence of counsel at defendant's preliminary hearing, the District of Columbia Circuit Court of Appeals relied, in part, on the argument that defendant might have been free on bail if he had been provided with counsel at that stage. Dancy v. United States, 361 F.2d 75 (D.C. Cir. 1966).

451 See text at note 418 supra.

452 The statute does not require that defendants plead to the charges prior to the arraignment. ILI. REv. StaT. ch. 38, § 109-1 (preliminary hearing), § 113-1 (arraignment) (1967); but in practice the arraignment and preliminary hearing are often combined in misdemeanor cases at the initial court appearance. See OAKs \& LeHMAN 38. In felony cases it is apparent that defendants need not plead to the charges before a probable cause hearing. ILL. REv. STAT. ch. 38, § 109-3(a) (1967). In light of the fact that a felony defendant has a right to a probable cause determination at the preliminary hearing, it can be argued that this is a "critical stage" since successful challenge to the probable cause for arrest could result in immediate release. Moreover, defense counsel can force the prosecution to reveal the evidence on which the charge is based. See Gramenos, Investigation and Discovery in a Criminal Case, 49 ChI. BAR Ass'N REc. 386 (1968); OARs \& LehMAN 115-6; see generally ATtorney General's Committee 44.
} 
because the Public Defender's office claimed it could represent all the defendants. Many defendants who otherwise might have secured private counsel were thus forced to rely on the assistance of the Public Defender. Assuming that many of the volunteer attorneys who were turned away would have been responsive to the personal interests of the defendants, it is arguable that the defendants were "substantially prejudiced" by ineffective representation by the Public Defender's office.

The importance of the presence of counsel at the bail hearing is underscored by the absence of effective remedies for excessive bond determinations. ${ }^{453}$ In practice, as our data indicate, the constitutional right to reasonable bail may be "irretrievably" lost if unprotected by provision for the presence of effective defense counsel at the bail hearing.

2. Later Proceedings. Eighty-seven per cent of those riot defendants brought before magistrates in the Municipal Court subsequent to their bail hearings were represented by the Public Defender. Only $10 \%$ of the defendants made written defense motions. Of the 221 defendants who made a third court appearance in the Municipal Court, $57 \%$ made defense motions.

TABLE 53

Disposimion of Defense Motions Made at Second and Third Court Appearances

\begin{tabular}{|c|c|c|c|c|}
\hline \multirow[b]{2}{*}{ Motion } & \multicolumn{2}{|c|}{ Second Court Appearance } & \multicolumn{2}{|c|}{ Third Court Appearance } \\
\hline & $\begin{array}{c}\text { Total Number } \\
\text { Made }\end{array}$ & $\%$ Granted & $\begin{array}{c}\text { Total Number } \\
\text { Made }\end{array}$ & $\%$ Granted \\
\hline $\begin{array}{l}\text { Stay of Mittimus } \\
\text { Suppression of Evidence }\end{array}$ & $\begin{array}{r}(111) \\
(41)\end{array}$ & $\begin{array}{l}98 \\
66\end{array}$ & (31) & $\frac{10}{-}$ \\
\hline Advance Court Date & (15) & 100 & - & - \\
\hline Vacate Judgment & (18) & 6 & (30) & 3 \\
\hline $\begin{array}{l}\text { Vacate Bond Forfeiture } \\
\text { Judgement }\end{array}$ & (13) & 92 & (52) & 98 \\
\hline Demand Trial & (9) & 0 & - & - \\
\hline Other Motions & (26) & - & (12) & - \\
\hline & $\overline{(233)}$ & & $\overline{(125)}$ & \\
\hline
\end{tabular}

As Table 53 indicates, when defense motions were made, they were generally limited to one of only five types of motions at the second court appearance and to one of only three types of motions at the third court appearance. Other motions which might have

453 See Blue v. United States, 342 F.2d 894 (D.C. Cir. 1964), cert. denied, 380 U.S. 944 (1965); text at notes 303-10 supra. 
been advantageous to individual defendants, including motions to dismiss, for discovery, for writ of habeas corpus, to strike the complaint, and for a bill of particulars were rarely if ever made. Motions to advance the court date and stay mittimus were almost always granted, at least at the second court appearance. The failure of the Public Defender to make greater use of such motions to protect his clients from long pretrial incarceration is unexplained.

The ineffectiveness of the Public Defender's representation of riot defendants in later stages is also reflected in the pattern of disposition of misdemeanor cases. (See Tables 54 and 55.) Only 27\% of the mis-

TABLE 54०

Disposition of All Misdemeanors by Type of Counsel

\begin{tabular}{lcccc}
\hline & \multicolumn{2}{c}{ Private Attorney } & \multicolumn{2}{c}{ Public Defender } \\
\hline Per Cent Convicted & 13 & $27 \%$ & 24 & $54 \%$ \\
$\quad$ Plea of Guilty & 14 & & 30 & \\
$\quad$ Convicted at Trial & & 73 & & 46 \\
Per Cent Released & 57 & & 15 & \\
$\quad \begin{array}{l}\text { Pretrial Dismissal } \\
\text { Discharge at Trial }\end{array}$ & 16 & $100 \%$ & & $100 \%$ \\
Total & & $(97)$ & & $(1189)$ \\
Number of Cases & & & & \\
\hline
\end{tabular}

TABLE 55

Disposition of Serious Misdemeanors by Type of Counser

\begin{tabular}{lcccc}
\hline & \multicolumn{2}{c}{ Private Attorney } & \multicolumn{2}{c}{ Public Defender } \\
\hline Per Cent Convicted & 5 & $12 \%$ & 22 & $35 \%$ \\
Plea of Guilty & 7 & & 13 & \\
Convicted at trial & & 88 & 60 & \\
Per Cent Released & 75 & & 5 & \\
$\quad$ Pre-trial Dismissal & 13 & & & $100 \%$ \\
Discharged at trial & & $100 \%$ & & $(174)$ \\
Total & & $(41)$ & & \\
Number of cases & & & &
\end{tabular}

demeanants represented by private attorneys were convicted, but twice that percentage, or $54 \%$, of misdemeanants represented by the Public Defender were convicted.

Not only were the misdemeanants represented by private counsel much less likely to be convicted, but, significantly, their cases were likely to be dismissed earlier in the criminal process. While $57 \%$ of private counsel cases were dismissed prior to trial, only $31 \%$ of 
Public Defender cases were dismissed before trial. The Public Defender was also more likely to plead his defendant guilty and more likely to go to trial with his case.

It might be suggested that these differences reflect the types of cases handled by private attorneys and the Public Defender, since a greater proportion of the cases handled by private attorneys involved serious charges, and these were likely to be disposed of earlier and more favorably to the defendant. We examined this possibility by analyzing the dispositions of those charged with "serious" misdemeanors-misdemeanors against the person or property. Our findings generally refute this hypothesis. Indeed, the overall conviction rate of serious misdemeanants represented by the Public Defender was almost three times as great as the rate in private counsel cases. The private attorney was far more successful at trial than the Public Defender, who was much more likely to settle for a plea of guilty.

In short, the defendant represented by a Public Defender received less effective legal representation than the defendant represented by a private attorney. The representation afforded riot defendants by the Public Defender was no more effective at later stages than it was during the earlier proceedings.

\section{G. The Public Defender and Effective Representation}

Based on its study of the civil disorders of 1967, the Kerner Commission concluded: "Most prominent in the major outbreaks was the shortage of skilled defense lawyers to handle the influx of cases in any fashion approximating individual representation. . . . The need for prompt, individual legal counsel is particularly acute in riot situations. . . The services of counsel at the earliest stage, preferably at the precinct station, are essential." 454

Illinois statutes permit implementation of the Kerner Commission recommendations by providing for appointment of public or private counsel at the initial court appearance of any indigent who desires counsel in all misdemeanor and felony cases in Cook County. ${ }^{455}$ And in fact most of the persons arrested during the April 1968 disorders were represented by counsel. As we have seen, virtually all the riot defendants were represented by the Public Defender at early stages in the criminal proceedings, and most of those with less serious charges were represented by the Public Defender throughout their prosecution. ${ }^{456}$ But the Kerner Commission also wrote that "[t]he

454 KeRNer Commission REPORT 186.

455 ILL. REv. STAT. ch. 38, $\$$ 109-1(b)(2), 113-8(b) (1967).

456 See Tables 51, 52 supra. 
right to counsel is a right to effective counsel." ${ }_{457}$ We noted earlier that the Public Defender, in many instances, was ineffective in representing riot defendants at their bail hearings. Our data also showed that misdemeanor defendants represented by the Public Defender were more likely to plead guilty and to be convicted after trial, and less likely to have their cases dismissed at pretrial stages, than their counterparts represented by private atorneys. It is important to note that the Public Defender has a similar record under "normal" circumstances, although the disparity of performance is perhaps less extreme. ${ }^{458}$

Perhaps the variations we have found in the effectiveness of representation in Cook County could be attributed to the relative ability of counsel. ${ }^{459}$ But more significant in an analysis of the representation afforded riot defendants is the purpose and function of a Public Defender's office. The most insistent criticism of public defenders is that they lack independence from other officials of the criminal system ${ }^{460}$ both because of their continuous working relationship with prosecutors and judges and because of the organizational set-up of public defenders' offices. Cook County public defenders are assigned to particular courts and must take all assigned cases in that courtroom. In addition, a judge or magistrate can pressure the Public

457 KeRNER COMMIISSION REPORT 354.

458 In 1964 the Cook County Public Defender was less likely than retained attorneys to get cases against felony defendants dismissed before trial and more likely to represent defendants pleading guilty, but had an overall conviction record roughly equivalent to that of retained lawyers. OARs \& LEHMAN 155-63. But analysis of a sample of 1965 felony cases in Cook County reveals that defendants represented by the Public Defender were more likely to be convicted than defendants represented by retained attorneys. Banfield \&. Anderson, Continuances in the Cook County Criminal Courts, 35 U. CHI. L. REv. 259, 303 Table 11 (1968). Lee Silverstein has offered evidence that a defendant represented by the Cook County Public Defender is more likely to plead guilty than a defendant represented by retained lawyers. L. SILverstein, Defense of the Poor 54 (1965). The Silverstein survey includes a similar comparison of public defenders and retained counsel on a nationwide basis. Supra at 53-56.

The University of Chicago Law Review continuances study also indicates that $80 \%$ of the indicted felons in the sample represented by retained attorneys were released on bail, as opposed to $38 \%$ of those represented by the Public Defender. Banfield \&. Anderson, supra at 304, Table 15. Data from the same study also show that retained attorneys filed over twice as many motions on behalf of defendants as the Public Defender. Supra at 309 Table 22.

459 Oaks and Lehman suggest, for example, that the variations in effectiveness of representation in. Cook County are attributable to four factors: "ability of counsel, type of crimes, difficulty of cases, and irascibility of defendants." OAKs \& LEHMAN 154-5.

460 Silverstein, supra note 458, at 50. See also OAKs \& LEHMAN 153. Even a federal judge has asserted that the public defender reflects "the creation of a police state where the government, when it prosecutes a man, purports also to defend him." Dimoch, The Public Defender: A Step Towards a Police State? 42 A.B.A.J. 219, 220 (1956). 
Defender's office to substitute one Assistant Public Defender for another. Public Defenders are appointed by, and serve at the pleasure of, a majority of the Judges of the Circuit Court.

In fact the Cook County Public Defender's office was not created and is not maintained for the primary purpose of providing effective representation for indigent criminal defendants. From its beginning the public defender movement in the United States was based as much on the needs of judicial economy as on humanitarian considerations. ${ }^{401}$ Indeed, when a committee of the Chicago Bar Association (CBA) summarized the advantages of the recently established Cook County Public Defender in 1931, it emphasized the expeditious handling of court matters. ${ }^{462}$ The Cook County Board of Commissioners continually stresses the fiscal economies of the public defender system in its Annual Reports; ${ }^{463}$ the present Public Defender of Cook County has reaffirmed the view that his office has remedied "a chaotic situation in the administration and disposition of cases." ${ }^{464}$

The effectiveness of the Public Defender, then, is more likely to be measured, at least among court officials, by his success in efficiently handling heavy caseloads than by his success in representing an indigent defendant. In short, the Cook County Public Defender is forced to serve as a functionary of the court. ${ }^{465}$ The significance of his role is highlighted by the exceptional unassertiveness of the State's Attorney's office in the early screening of cases. ${ }^{466}$

401 As one of the early leaders in the public defender movement said in arguing for a public defender system in New York: "No law could be more economical-none more humane." M. Goldman, The Public Defender (1917).

402 The committee listed as advantages of the Public Defender's office: (1) If the defendant "has no case" he is advised to plead guilty in order to avoid unnecessary trials; (2) if he has "a good case" he is given an adequate defense; (3) jury trials are often waived; (4) cases are tried promptly, not continued "time after time"; (5) cases are tried expertly and the time of the court is not "wasted by needlessly protracted trials"; (6) "vast economies are effected"; (7) judges rely upon the Public Defender's opinion in sentencing; (8) unethical practices are eliminated; and (9) there are "less chances for a miscarriage of justice." Mishkin, The Public Defender, 14 CHI. BAR Ass'N REc. 98, 106 (1931).

463 Working Paper 26. The Public Defender is appointed by a majority vote of the Judges of the Circuit Court and his budget is determined by the Circuit Court, but the budget of the Circuit Court is controlled by the County Board of Commissioners. See Working Paper 26-27; Harrington \& Getty, The Public Defender: A Progressive Step Towards Justice, 42 A.B.A.J. 1139, 1140 (1956).

464 Harrington \& Getty, supra note 463 , at 1141 .

405 "While the assistants did not see themselves as bureaucratic functionaries and did not act as such, both the clients and the courtroom personnel did see them as bureaucratic functionaries. Many judges and much of the rest of the courtroom personnel con. ceived of the most important Public Defender function as expediting court business and 'efficiency' as the primary goal." Working Paper 105.

468 See text at note 61 supra. In 1931 the Wickersham Commission, noting that the one advantage of a public defender system "which seems best established is that ... 
The effectiveness of the Public Defender in representing his clients' interests, under conditions of civil disorder as well as under normal circumstances, is best understood in light of the policies and goals of the criminal system. Under normal conditions the criminal system aims at attaining maximum efficiency in the application of "appropriate sanctions" consistent with due process. Under conditions of civil disorder the policy of the Cook County courts differs from this goal primarily in the redefinition of "appropriate sanctions" to include preventive detention. ${ }^{467}$

Thus the Public Defender's policy of representing all riot defendants at the initial bail hearings-regardless of indigency, and despite overload and the presence of volunteer attorneys-can best be explained in terms of the goals of the criminal system. Indeed, this "monopoly" policy has since been institutionalized by a mass arrest contingency plan of the Cook County Circuit Court. ${ }^{408}$ The plan delegates the coordination of private defense efforts to the CBA in cases in which the defendant requests counsel other than the Public Defender, and is apparently designed to maintain the primary role of the Public Defender in supervising defense efforts. ${ }^{469}$ By utilizing the services of the CBA the Public Defender is able to avoid direct contact with more aggressive and independent legal groups such as the ACLU, the Cook County Bar Association, and legal aid organizations, and thereby protect the courts' interests in efficient administration. As one official from the Public Defender's office described the situation during the April riots:

$[T]$ he ACLU or their attorneys would take no directions from me. Now, they all wanted to do the same job, but it was only the Chicago Bar Association that said 'how many lawyers do you want; we'll send them there the hour you want; and you direct them.'470

[the system] involves economy," withheld general approval of a public defender system because it believed the chief advantage could equally be obtained through proper performance of the "preliminary sifting" function by prosecutors. U.S. NATIONAL CoMmission on Law Observance and EnForcement, Report on Prosecution 33 (1931).

467 See text at notes $395-8$ supra.

468 General Order of the Circuit Court of Cook County No. 18 (1968). The Order provides, in part:

E. If the defendant is without counsel, the Court shall appoint the Public Defender of Cook County to defend him.

F. If the defendant requests counsel other than the Public Defender of Cook County, the Court shall appoint a member of the Chicago Bar Association Volunteer Lawyers Committee to represent the defendant.

Id., $\S 18.8, \llbracket \uparrow \mathrm{E}, \mathrm{F}$.

469 See Cawley Testimony at 220.

470 Id. at 225-6. 
We noted earlier in this section that the Public Defender often failed to make bond recommendations and to elicit relevant information from riot defendants at the bail hearings, despite apparent evidence that a more forthright defense would have effectively represented the defendants' interests. To some extent, perhaps, our findings are attributable to the energies and motivations of Public Defender personnel. Much more significant, however, was the policy of the criminal system to discourage individualized and detailed bail hearings. It is likely that even if volunteer attorneys had been allowed to participate actively in the defense effort at early stages, the results would not have been substantially different. The policies of the Cook County courts under conditions of civil disorder may tolerate the aberration of a few privately represented defendants at bail hearings, but it is doubtful that the system would permit the mass participation of aggressive private attorneys.

In this light, however, the increased participation by private counsel at later stages in the criminal proceedings is particularly significant. Once the riot had subsided, and the desire to detain arrestees and safeguard administrative efficiency had moderated, representation by more aggressive private attorneys became less incompatible with the policies of the criminal system. ${ }^{471}$

The function of the Public Defender's office to regulate the administration of the courts and safeguard the attainment of efficiency and economy, particularly under conditions when those goals are most in jeopardy, results in a conflict of interest with serious implications for the operation of the criminal justice system. ${ }^{472}$ And as we noted earlier, appellate relief may not be available, thus highlighting the necessity for a stern reevaluation of the effectiveness of current forms of defense representation in protecting the interests of indigent defendants.

471 Despite the experience of April 1968, the First Assistant Public Defender has claimed that the Public Defender's office can in the future handle up to three thousand riot defendants at initial bail hearings. The office's contingency plans expressly anticipate that few private volunteers will "come in" at initial bail hearings. Volunteers will be encouraged to join the defense effort at later stages both as interviewers and as regular counsel. $I d$. at 234 .

472 In cases involving private appointed counsel at least, such conflict of interest may be grounds for automatic reversal. See People v. Stoval, 40 Ill. 2d 109, 239 N.E.2d 441 (1968), where the fact that appointed counsel had once represented the plaintiff, and that his firm was still retained by plaintiff, was held sufficient to grant a new trial. "This situation is too fraught with the dangers of prejudice, prejudice which the cold record might not indicate, that the mere existence of the conflict is sufficient to constitute a violation of relator's rights whether or not it in fact influences the attorney or the outcome of the case." 40 Ill. $2 d$ at 113, 239 N.E.2d at 443. 


\section{CONCLUSION}

Givil disorders pose a special threat to any criminal justice system. They bring a massive influx of cases into already overtaxed courts. In the absence of preparation, as the Kerner Commission warned, the result may be recurring breakdowns in the administration of justice. ${ }^{473}$ This study has indicated that Chicago had a virtually complete plan-predicated in part on the earlier experiences of Chicago and other cities and on Kerner Commission recommendations-for handling mass arrest cases. ${ }^{474}$

The contingency plan put into effect in April 1968 emphasized the goal of economy in judicial administration and the role of the State's Attorney and Public Defender in safeguarding the achievement of that goal. The State's Attorney relied heavily on misdemeanor rather than felony charges; he also relied on curfew, disorderly conduct, and burglary charges, rather than mob action and looting, which would have involved more difficult evidentiary burdens. Form complaints were used. Preliminary hearings were avoided in most felony cases, and automatic continuances were granted in.virtually all misdemeanor cases. Bail was generally set at uniform amounts based on the State's Attorney's recommendations and the nature of the offense charged. ${ }^{475}$ Defense lawyers were not allowed to participate in the post-arrest screening process and were unable to interview prisoners individually in precourt detention facilities. ${ }^{476}$ Volunteer attorneys, law students, and interviewers were not deployed effective-

473 KeRNER COMMISSION REPORT 184.

474 The Austin Committee also concluded that the Cook County judiciary "was not without an emergency plan during the April riots." Austin COMMITTEe Report 88. Moreover, future mass arrest situations in Chicago will probably be handled in much the same manner as the April 1968 riot cases. After the April disorder, Chief Judge Boyle remarked: "I've been a lawyer for 42 years and this is the finest example of processing in mass arrests $I$ have ever seen." Chicago Tribune, April 13, 1968, at 6. The Administrative Assistant to the Chief Judge said, "we were very pleased with the extreme efficiency with which these plans worked." Los Angeles Times, May 27, 1968, § 1, at 7.

Both the Chicago Police Department and Cook County Circuit Court issued orders after April 1968 establishing procedures for the processing of mass arrests defendants. See Austin Commitree Report app. D; General Order of the Circuit Court of Cook County No. 18 (1968). The new court plan does not differ significantly from the procedures employed in April 1968. There is, in particular, no indication that the policy of pretrial detention will be abandoned. In briefing magistrates for duty during the August 1968 disturbances which surrounded the Democratic National Convention, Chief Judge Boyle made it clear that high bonds would be an effective way to keep "violent persons" off the streets. Chicago Sun-Times, August 20, 1968, at 7.

475 See KERNER COMMISSION REPORT 191-2.

476 See KERNer COMMISSION REPORT 192. 
ly. ${ }^{477}$ Bond reduction hearings were delayed for many defendants until well after the riot had ended. By representing virtually all riot arrestees at the bail hearing regardless of indigency, and most riot defendants at later stages, and by failing to request early bond reduction hearings, the Public Defender contributed to judicial efficiency.

The goal of judicial economy, however, is significant not so much as a bureaucratic-administrative ideal but as a potential means of assuring due process. When the Kerner Commission lamented recurring breakdowns in judicial administration during civil disorders it hoped to provide an impetus for protecting defendants' rights. Indeed, contingency planning for civil disorders is important primarily because it affords a means of avoiding abuses of due process. ${ }^{478}$ But in Chicago, judicial efficiency was perceived mostly in terms of system goals other than due process. Insofar as the goal of efficient administration resulted in the availability of facilities and personnel to process arrestees, it worked toward both administrative ends and due process. But more often the administrative goal impeded attainment of due process, as is evidenced, for example, by uniform bond amounts, avoidance of preliminary hearings, delay of bond reduction hearings, and the role of the Public Defender. In short, the Chicago plan achieved efficient administration but without achieving the end of due process which judicial economy was presumably intended to serve.

Moreover, the Cook County criminal system apparently sacrificed measures of efficiency when necessary to the attainment of other goals. Some Kerner Commission recommendations which would have expedited judicial processing were rejected. No use was made of summons in lieu of arrest, or preset bail schedules for which Illinois statutes provided and which the Commission endorsed.479

477 See KERNER COMMIISSION REPORT 193.

478 See Open Meeting Before the Illinois State Advisory Committee to the United States Commission on Civil Rights 156-7 (June 12, 1968) (Testimony of Harvey Friedman). See also Vance, The Administration of Justice in Civil Disorders, $51 \mathrm{~J}$. AM. JuD. Soc' $\mathrm{Y} 326$ (1968). Riot contingency recommendations regarding the administration of justice are numerous. See, e.g., American Bar Association Section on Criminal Law, Bar Leadership and Civil Disorders (1968); National District Atrorneys Association, Guidelines for Prosecuting Criminal Cases During Civil Disorders (1968); R. Goldfarb, The administration of Justice in Washington, D.C., During the Disorder of April 1968, at 58.74. A special subcommittee of the Lawyers' Committee for Civil Rights is active in assisting local communities to develop contingency plans for the administration of justice during civil disorders. Testimony of Harvey Friedman, supra at 148-50. Such plans have been adopted in many cities including New York, Washington, and Baltimore. Testimony of Harvey Friedman, supra at 151-5.

479 See Kerner Commission Report 189-91. The summons in lieu of arrest procedure is authorized by Irl. REv. Stat. ch. 38 , § 107-12 (1967). 
That fact as well as deliberate and inefficient police processing of riot arrestees, and the absence of facilities which would have permitted immediate posting of cash bail, suggest that some inefficiencies were tolerated and perhaps designed in order to achieve other goals, such as pretrial detention. This study has highlighted the importance of each discretionary determination by police, prosecutor, public defender, and magistrate resulting in temporary detention of riot arrestees. Predictable breakdowns in the handling of riot arrestees at detention facilites did not result in the abandonment of the policy of pretrial detention. Indeed, rather than abandon that policy some previously convicted prisoners were released.

The use of pretrial detention is significant not only as a reflection of the desire to avoid inefficiencies of formal adjudication at trial but also because it achieves other goals of the criminal system. Pretrial detention is thought to be an effective form of punishment and a measure of general deterrence. It is also conducive to attaining high conviction rates ${ }^{400}$ which constitute a public record of effective punishment of rioters. Its use perhaps reflects the inadequacy of formal criminal processes in achieving the deterrent purposes of the criminal law. In effect, pretrial detention accelerates the impact of criminal sanctions through informal and discretionary processes. Formal adjudication, findings of guilt, and sentencing are, for many, a mere formality. The hurried judgments and unarticulated policies of police and national guard officers become critical, result in the unjustified inconvenience for many of multiple court appearances, and are, in practice, not subject to review.

The use of pretrial detention for deterrent purposes during riots is particularly suspect in light of the fact that, at least in Chicago, it was not the initial rioters or looters who were arrested but what one Cook County official called the "mopes and gawkers" who took advantage of the breakdown in law enforcement. More important, the tendency to rely on informal pretrial criminal sanctions raises serious doubts about the prevailing rule that there is no constitutional or statutory right to a preliminary hearing, in the absence of a showing of actual prejudice at the formal disposition of a defendant's case. It may not be accidental that the locus of informal criminal sanctions is at early stages of criminal prosecution where a defendant's rights

\footnotetext{
480 Although the Kerner Commission expressly rejected use of preventive detention it encouraged the "conviction of those who riot, incite to riot or have committed acts of physical violence or caused substantial property damage," and criticized low conviction rates among Detroit, Newark, and Los Angeles riot arrestees. KERNER CommLssIoN REPORT $184,186-7$.
} 
and ability to take himself out of the criminal process are most tenuous.

Riot contingency planning is an inadequate response to civil disturbances, then, not only because it offers little assurance of due process, but also because it fails sufficiently to recognize that there are goals of the criminal system during civil disorders which are in tension with the requirements of both efficiency and due process. Furthermore, for most urban criminal systems, contingency plans would require the adoption under extraordinary circumstances of policies and procedures presently unattained under ordinary conditions.

Perhaps the most distressing implication of the study is that the quality of justice dispensed during civil disorders is in many respects only a reflection of the reality of criminal administration under normal conditions. Riots and the ensuing responses of criminal systems are highly visible and politically volatile phenomena. It is not the administration of criminal justice, but society's concern about the criminal justice system which is altered most radically during civil disorders. ${ }^{481}$ The overwhelmingly urgent task is to sustain from dayto-day the critical attention focused on our cities and lower criminal courts in the aftermath of civil disorders. ${ }^{482}$ Only basic social and judicial reforms will ultimately secure fair and effective administration of criminal justice in urban America.

481 Many private attorneys who were shocked by the operation of the criminal process in April 1968 were not familiar with its normal operation. The First Assistant Public Defender has remarked that many of the volunteer lawyers who complained about conditions on the riot weekend had no experience in Cook County courts. They had nothing against which to gauge what they saw. Los Angeles Times, May 27, 1968, § 1, at 7 .

482 Urban America, Inc. and the Urban Coalition have recently completed an assessment of the nation's response to the crisis described by the Kerner Commission. In regard to the lower criminal courts the study concluded only that "the significant thing about the last year is that nothing can be pointed to." Urban AMERuca, INc. \& URBan Conittion, One Year Later 77 (1969). 